\title{
The jacoona assemblage of the genus Dundubia Amyot \& Serville (Homoptera: Cicadidae): a taxonomic study of its species and a discussion of its phylogenetic relationships
}

\author{
Paul L.Th. Beuk \\ Institute for Systematics and Population Biology (Zoological Museum), University of Amsterdam, Plantage \\ Middenlaan 64, NL-1018 DH Amsterdam, The Netherlands
}

Keywords: Cicadidae, Dundubia, Jacoona assemblage, taxonomy, new species, phylogeny

\begin{abstract}
The species of Orientopsaltria with unicolorous opercula and three related species of Platylomia are transferred to the genus Dundubia and allocated in the 'Dundubia jacoona assemblage' pending further investigation. The assemblage comprises eleven species in total; all are found in the Indo-Malaysian Archipelago, Indo-China, and the adjoining parts of China and India. The four species which were until now placed in Orientopsaltria are $D$. feae (Distant, 1892), D. jacoona (Distant, 1888), D. nigripes (Moulton, 1923), and D. oopaga (Distant, 1881). The three species transferred from Platylomia are $D$. hainanensis (Distant, 1901), D. nagarasingna Distant, 1881, and D. spiculata Noualhier, 1896. These seven species are all redescribed. Four species are described as new: $D$. ayutthaya, $D$. laterocurvata, D. myitkyinensis, and $D$. sinbyudaw. Seven species are synonymized: $O$. andersoni (Distant, 1883) with $D$. oopaga, $D$. bifasciata Liu, 1940 with $D$. hainanensis, $O$. hastata (Moulton, 1923) and D. siamensis Haupt, 1918 with $D$. spiculata, O. fratercula (Distant, 1912) and D. helena Distant, 1912 with $D$. nagarasingna, and $D$. longina Distant, 1917 with $D$. feae. Lectotypes are designated for the following species: Cosmopsaltria andersoni, C. feae, $C$. fratercula, C. hastata, $C$. nagarasingna, $C$. nigripes, $C$. oopaga, $D$. helena, $D$. longina, and $D$. spiculata. A key to the males is presented and the distributions of the species are discussed. The relationships of the D. jacoona assemblage with Dundubia, Platylomia, and the remaining species of Orientopsaltria are discussed. The species of the D. jacoona assemblage most likely do not form a monophyletic group on their own but rather with Dundubia s. str.
\end{abstract}

\section{Résumé}

Les espèces d'Orientopsaltria à opercules unicolores, ainsi que trois espèces apparentées de Platylomia sont transférées au genre Dundubia et placées dans le 'groupement de Dundubia jacoona' en attendant le résultat de recherches ultérieures. Le groupement comprend en total onze espèces à distribution dans l'Archipel Indo-Malais, en Indochine, et dans les zones limitrophes de Chine et d'Inde. Les quatre espèces jusqu'à présent placées dans Orientopsaltria sont $D$. feae (Distant, 1892), D. jacoona (Distant, 1888), D. nigripes (Moulton, 1923), et $D$. oopaga (Distant, 1881). Les trois espèces transférées de Platylomia sont D. hainanensis (Distant, 1901), D. nagarasingna Distant, 1881, et D. spiculata Noualhier, 1896. Toutes ces sept espèces sont redécrites. Quatre nouvelles espèces sont décrites: $D$. ayutthaya, $D$. laterocurvata, $D$. myitkyinensis, et $D$. sinbyudaw. Sept especes sont synonymisées: $O$. andersoni (Distant, 1883) avec $D$. oopaga, $D$. bifasciata Liu, 1940 avec $D$. hainanensis, $O$. hastata (Moulton, 1923 ) et $D$. siamensis Haupt, 1918 avec $D$. spiculata, $O$. fratercula (Distant, 1912) et $D$. helena Distant, 1912 avec $D$. nagarasingna, et $D$. longina Distant, 1917 avec $D$. feae. Des lectotypes sont désignés pour les espèces suivantes: Cosmopsaltria andersoni, C. feae, C. fratercula, C. hastata, C. nagarasingna, $C$. nigripes, $C$. oopaga, $D$. helena, $D$. longina, et D. spiculata. Une clé pour l'identification des mâles est présentée, et la distribution des espèces est discutée. Sont aussi discutées les relations du 'groupement de D. jacoona' avec Dundubia, Platylomia, et avec les espèces qui restent dans le genre Orientopsaltria. Il est fort probable que les espèces du 'groupement de $D$. jacoona' ne représentent pas un groupe monophylétique à elles seules, mais plutôt ensemble avec celles de Dundubia s. str.

\section{Introduction}

The present paper investigates the identities and relationships of the species of Orientopsaltria Kato, 1944, with unicolorous opercula and related species in the genera Dundubia Amyot \& Serville, 1843, and Platylomia Stăl, 1870. These species are transferred to Dundubia and the 'Dundubia jacoona assemblage' is introduced to accommodate them. The genera mentioned belong to the cicada subtribe Dundubiaria of the tribe Dundubiini together with Macrosemia Kato, 1925, Meimuna Distant, 1905, Haphsa Distant, 1905, Ayesha Distant, 1905, and Khimbya Distant, 1905 (Duffels \& 
Van der Laan, 1985). This subtribe is distributed throughout a large part of Southeast Asia.

The genus Orientopsaltria was erected by Kato (1944a) to accommodate species of Cosmopsaltria Stål, 1866, that differed from other species of that genus in having rounded instead of spine-like lateral pygofer lobes. In the description Orientopsaltria was only compared with Cosmopsaltria and not with a number of other genera that also have rounded lateral pygofer lobes, e.g. Dundubia and Platylomia. Duffels (1983) formally redefined Cosmopsaltria and transferred all Cosmopsaltria species with rounded lateral pygofer lobes to Orientopsaltria, but he did not define Orientopsaltria in relation to other genera with rounded lateral pygofer lobes either.

Overmeer \& Duffels (1967) gave an historic overview of the composition of the genus Dundubia and revised all species placed in the genus at the time. A phylogenetic analysis was not performed and the monophyly of the genus was assumed implicitly by treating it as a whole. Overmeer \& Duffels noted the shared feature of the rounded lateral pygofer lobes of Orientopsaltria and Dundubia and suggested a close relationship between both genera. The main feature to distinguish between the two genera supposedly was the presence of fuscous spots on the tegmina in Orientopsaltria and the absence of such spots in Dundubia.

After Duffels (1983) transferred to Orientopsaltria the species with rounded lateral pygofer lobes that were until then placed in Cosmopsaltria, he distinguished two groups in Orientopsaltria. One group was characterized by unicolorous opercula and a globose head, the other by bi- or multicolorous opercula and a less globose head. The species of the first group resemble many species of Dundubia and some species of the diverse genus Platylomia. The 'Dundubia jacoona assemblage' is created to accommodate these species awaiting further research on the generic distinction between Orientopsaltria, Dundubia, and Platylomia which is presently still unclear.

The Dundubia jacoona assemblage at present comprises eleven species (including four new), distributed with certainty in northern India, Bangladesh, south-western China, Indo-China (Burma,
Cambodia, Laos, Thailand, Vietnam), Peninsular Malaysia, Borneo, and Sumatra. None of the records in the literature from the Andaman and Nicobar Islands, south-eastern China, and Japan could yet be confirmed.

The closest relatives of the $D$. jacoona assemblage are among the species of Dundubia s. str. [constituted by Dundubia vaginata (Fabricius, 1787), the type species of Dundubia, and relatives] and the group formed by Platylomia radha (Distant, 1881) and relatives.

\section{Material and methods}

References in the literature to species treated below were checked whenever possible. Older references were traced using Metcalf (1963a, b) and Duffels \& Van der Laan (1985). References that could not be checked are marked with an asterisk $(*)$.

The following abbreviations have been used for collections mentioned in the descriptions:

BMNH Natural History Museum, London (formerly British Museum Natural History)

BPBM Bernice P. Bishop Museum, Honolulu

CUIC Cornell University Insect Collection, Department of Entomology, Cornell University, Ithaca, New York

MCZ Museum of Comparative Zoology, Harvard University, Cambridge, Massachusetts

MNP Muséum National d'Histoire Naturelle, Paris

MSNG Museo Civico di Storia Naturale 'G. Doria', Genova

NLHD Niedersachsisches Landesmuseum, Hannover

NHMW Naturhistorisches Museum, Wien

RMNH Nationaal Natuurhistorisch Museum (formerly Rijksmuseum van Natuurlijke Historie), Leiden

ROME Royal Ontario Museum, Toronto

SEM Snow Entomological Museum, Lawrence, Kansas

TARI Taiwan Agricultural Research Institute, Taichung

UKMS Universiti Kebangsaan Malaysia, Bangi, Selangor

USNM Unites States National Museum, Smithsonian Institution, Washington D.C.

UZMK Universitets Zoologiske Museum, København

ZMA Zoölogisch Museum, Universiteit van Amsterdam, Amsterdam

The following geographical sources have been consulted: 'Andrees allgemeiner Handatlas' (Anonymous, 1906), 'Atlas van Tropisch Nederland' (Anonymous, 1938), 'The Times Atlas of the World' (Anonymous, 1994), 'Chambers World Gazetteer' (Munro, 1988), 'Nelles Road Atlas Indonesia' (Anonymous, 1992a), 'Nelles Road Atlas Southeast Asia excluding Indonesia' (Anonymous, 1992b), 'Thailand, Indochina \& Burma Handbook' (Eliot et al., 1994), and GEOnet Names Server of the U.S. Defence Mapping Agency (WWW URL: http:// www.dma.gov/gns/html/index.html). 
Arrows in illustrations point to certain important features mentioned in the descriptions or other parts of the text.

\section{Phylogeny}

\section{The Dundubia jacoona assemblage}

The $D$. jacoona assemblage is created for the purpose of bringing together species with similar features that were previously attributed to different genera. The species are brought together in an assemblage because they do not form a monophyletic group. The features shared by all or almost all species of the assemblage are: possession of a globose postclypeus, absence of distinct markings on the tegmina, reduction of the black markings and fasciae on head and pronotum, and possession of unicolorous opercula.

The assemblage is placed in the genus Dundubia because it shares the apomorphic globose postclypeus and the absence of markings on the tegmina with Dundubia s. str., though the latter character is also found elsewhere in the Dundubiaria. It is uncertain if the absence of markings is apomorphic and whether this character can be used to establish the monophyly of the $D$. jacoona assemblage with Dundubia s. str.

The study of the $D$. jacoona assemblage leads to the following list of species and synonymies: $D$. feae (Distant, 1892) n. comb. [=D. longina Distant, 1917: n. syn.], D. jacoona (Distant, 1888) n. comb., D. nigripes (Moulton, 1923) n. comb., and D. oopaga (Distant, 1881) n. comb. $[=O$. andersoni (Distant, 1883): n. syn.]: all transferred from Orientopsaltria; D. hainanensis (Distant, 1901) $\mathrm{n}$. comb. [=D. bifasciata Liu, 1940: n. syn.], D. nagarasingna Distant, $1881[=O$. fratercula (Distant, 1912): n. syn., and D. helena Distant, 1912: n. syn.], and D. spiculata Noualhier, 1896 [= $O$. hastata (Moulton, 1923): n. syn., and D. siamensis Haupt, 1918: n. syn.]: all transferred from Platylomia; $D$. ayutthaya n. sp., D. laterocurvata $n$. sp., D. myitkyinensis n. sp., and D. sinbyudaw n. sp.

Within the $D$. jacoona assemblage three groups can be distinguished: the $D$. nagarasingna group (D. nagarasingna, D. feae, D. hainanensis, and $D$. mvitkvinensis $\mathrm{n}$. sp.), the $D$. jacoona group ( $D$. jacoona: D. oopaga, and D. ayutthaya n. sp.), and the $D$. spiculata group (D. spiculata, D. laterocurvata n. sp., and $D$. sinbyudaw n. sp.).D. nigripes cannot be placed in either of these three groups.

The $D$. nagarasingna group has two distinct features. The first is that the mediodistal corners of the uncus lobes are produced into medial projections that lie on the inside of the uncus, dorsal of the outer surface of the uncus lobes (as in Figs. 6, 38-40) (character 10 below). The second feature of this group is the presence of a distinct semicircular ridge running from one uncus lobe to the other (as in Fig. 6) (character 14 below).

The $D$. jacoona group is characterized by an indentation in the lateral margins of the broad uncus lobes (as in Fig. 51) (character 13 below).

The $D$. spiculata group, compared to the other two groups and $D$. nigripes, has almost entirely lost the colour pattern on the head and pronotum (characters 1 and 3 below) but has a black posterior margin of the pronotal collar.

$D$. nigripes has much elongated uncus lobes (character 11 below). The impression of elongation is even enhanced by the deep emargination of the lateral margin very close to the base of the uncus so that the uncus lobes are narrow from almost the base (Fig. 45). It shares none of the distinct features of the three groups above.

\section{Phylogenetic analysis}

A preliminary phylogenetic analysis with PAUP 3.1.1 was carried out with the purpose to investigate the relationships between the groups of the $D$. jacoona assemblage and $D$. nigripes, and between the D. jacoona assemblage and Dundubia s. str.; Platylomia and Orientopsaltria s. str. (the species with bi- to multicolorous opercula) were chosen as outgroups. The species groups of the $D$. jacoona assemblage were represented by the species giving the names to the respective groups and Dundubia s. str. by its type species $D$. vaginata. The genus Platylomia was represented by $P$. bocki (Distant, 1882) and Orientopsaltria s. str. by its type species $O$. duarum (Walker, 1857). Analysis was run under the ACCTRAN option. The characters are discussed below and the matrix is given in Table I. 
The analysis resulted in two equally parsimonious trees. One of the two resulting trees was identical with the (strict) consensus tree, the second showed ' $D$. nigripes $+D$. nagarasingna group' as a separate clade. The tree was rooted with the outgroups in a basal polytomy. The strict consensus tree is shown in Fig. 1.

\section{Discussion of the characters}

\section{Colour patterns}

1. Light-dark pattern on head and pronotal disc: (0) present; (1) absent.

Comment. - In the Dundubiini the head and the pronotal disc usually have a pattern of dark markings. This pattern generally at least consists of markings on the vertex and central fasciae on the pronotal disc but it sometimes covers most of the head and pronotal disc. In most species of the $D$. jacoona assemblage this pattern is still visible, but the markings are not dark brown or black but rather a darker shade of the ground colour of head and pronotum. Species like $D$. oopaga and $D$. ayutthaya are variable in this respect because the colour of the pattern varies from this darker shade of the ground colour to distinctly dark brown or black. Alternative to having a pattern, the head and pronotal disc can be completely unicolorous greenish to ochraceous. Complete reduction of the markings on both head and pronotal disc occurs in the D. spiculata group and Dundubia s. str. but rarely elsewhere in the Dundubiini.

2. Posterior margin of pronotal collar: (0) narrowly black; (1) concolorous with ground colour of collar.

Comment. - In the Dundubiaria the posterior margin of the pronotal collar generally is black (Fig. 54). In some species it is occasionally brown medially, but only rarely it is concolorous with the pale ground colour of the pronotal collar. A pale posterior margin of the pronotal collar occurs only rarely outside Dundubia s. str.

3. Markings on lateral part of pronotal collar: (0) present; (1) absent.

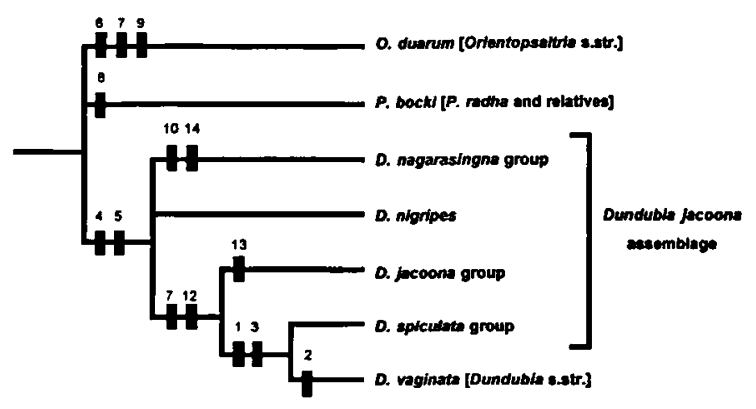

Fig. 1. Result of a preliminary analysis of the groups in the $D$. jacoona assemblage, $D$. nigripes and $D$. vaginata [Dundubia s. str.] with $P$. bocki and $O$. duarum as outgroups using PAUP 3.1.1 (exhaustive search, ACCTRAN option). The taxa or groups used in the analysis are mentioned in the text. Numbers indicate apomorphies; see Table I for the matrix and text for discussion of characters. The tree was rooted with the outgroups in basal polytomy. Tree statistics: $\mathrm{L}=15, \mathrm{CI}=0.933$, $\mathrm{RI}=0.875$.

Table I. Character matrix used in the preliminary analysis. The groups named are mentioned in the text. For discussion of characters, see text.

\begin{tabular}{|l|lllllllllllllll|}
\hline & 1 & 2 & 3 & 4 & 5 & 6 & 7 & 8 & 9 & 10 & 11 & 12 & 13 & 14 \\
\hline$P$. bocki & 0 & 0 & 0 & 0 & 0 & 0 & 0 & 1 & 0 & 0 & 0 & 0 & 0 & 0 \\
$O$. duarum & 0 & 0 & 0 & 0 & 0 & 1 & 1 & 0 & 1 & 0 & 0 & 0 & 0 & 0 \\
D. nagarasingna group & 0 & 0 & 0 & 1 & 1 & 0 & 0 & 0 & 0 & 1 & 0 & 0 & 0 & 1 \\
D. nigripes group & 0 & 0 & 0 & 1 & 1 & 0 & 0 & 0 & 0 & 0 & 1 & 1 & 0 & 0 \\
D. jacoona group & 0 & 0 & 0 & 1 & 1 & 0 & 1 & 0 & 0 & 0 & 0 & 1 & 1 & 0 \\
D. spiculata group & 1 & 0 & 1 & 1 & 1 & 0 & 1 & 0 & 0 & 0 & 0 & 1 & 0 & 0 \\
$D$. vaginata & 1 & 1 & 1 & 1 & 1 & 0 & 1 & 0 & 0 & 0 & 0 & 1 & 0 & 0 \\
\hline
\end{tabular}

Comment. - In the Dundubiini the presence of darker markings on the lateral part of the pronotal collar is widespread. In the case of a single marking on each side of the pronotal disc, this marking is situated near the anterolateral corner (Fig. 54) or the lateral margin of the pronotal collar (Fig. 61). In addition to this marking there can be markings that are situated near the posterolateral corner and/ or at the posterior margin of the lateral lobe of the pronotal disc. Alternatively, no markings may be present at all (Fig. 75). This latter condition occurs rarely outside the D. spiculata group and Dundubia s. str.

Head

4. Postclypeus globose: (0) no; (1) yes.

Comment. - In most species of the Dundubiini the 
postclypeus is rather flat. In dorsal view the anterior profile of the postclypeus is then angular rather than rounded and the postclypeus does not protrude much from between the vertex lobes. When the postclypeus is globose, this profile is rounded and the postclypeus clearly protrudes from between the vertex lobes (Figs. 54, 68).

A globose postclypeus was once deemed characteristic of Dundubia but it often proves to be variable within species. However, the feature of a globose postclypeus, even though variable within species, is virtually restricted to Dundubia s. str. and the $D$. jacoona assemblage.

\section{Tegmina}

5. Markings on tegmina: (0) present; (1) always absent.

Comment. - In the Dundubiaria many species have a pattern of markings on the tegmina besides the reticulation that is often visible in the cells in the distal and posterior part of the tegmina. The most elaborate pattern consists of markings at basal veins of the second, third, fifth, and seventh apical cells and the apices of longitudinal veins of the apical cells. A less elaborate pattern consists of just markings on the basal veins of the second and third apical cells. Intermediate patterns do occur with additional markings on the basal veins of the fifth and seventh apical cells, on the apices of longitudinal veins of apical cells in the distal part of the wing, or both. A pattern of markings can also be almost completely wanting but very indistinct markings sometimes are visible on the basal vein of the second apical cell.

A complicating matter is the occurrence of variation between apparently closely related species [e.g. M. opalifera (Walker, 1850) and related species] or within species. For the analysis $P$. bocki was used, a species with an indistinct pattern of markings on the tegmina that shows considerable variation: usually the basal veins of the second and third apical cells are infuscate and often also most of the apices of longitudinal veins of the apical cells. Alternatively only the markings on the basal veins of the second and third apical cells are vis- ible or none at all. In such cases species are scored as having markings on the tegmina (0).

Both presence and absence of markings on the tegmina do occur elsewhere in the Dundubiini and both states occur in groups that apparently are closely related.

\section{Opercula}

6. Colour of operculum: (0) unicolorous; (1) bi- to tricolorous.

Comment. - In the Dundubiaria the presence of a dark margin of the operculum on the part distal of the constriction is common. This dark margin may be broad or narrow and always includes the distal and medial margins and strongly contrasts to the otherwise largely greenish or ochraceous surface. In addition to this the central surface of the distal part of the operculum may have a distinct brown marking. In contrast, some species have unicolorous opercula that are completely greenish or ochraceous although they may be somewhat darker on the distal half. The darkening near the lateroproximal corner is here not taken into account.

Unicolorous opercula are present in the $D$. jacoona assemblage, Dundubia s. str., and $P$. radha and relatives, but also elsewhere in the Dundubiaria. They are also present in some groups of Meimuna [e.g. some of the species related to $M$. opalifera or M. tavoyana (Distant, 1888)] and elsewhere in Platylomia [e.g. P. larus (Walker, 1858) and related species]. Complicating the matter are species with completely dark brown to blackish opercula as is occasionally found in Platylomia.

7. Darkening near lateroproximal corner of operculum: (0) present; (1) absent.

Comment. - The operculum can have a small darkened area near the lateroproximal corner that starts at the proximal margin and can extend to the lateral margin in the constriction (Figs. 8, 14, 47). Alternatively, there is no such area. Both conditions (darkening present or absent) occur elsewhere in the Dundubiaria. 
Abdomen

8. Timbal coverings elongate: (0) no; (1) yes.

Comment. - In the Dundubiini the timbal coverings most often are shorter than wide at the base. Alternatively, the timbal coverings are at least as long to distinctly longer than wide at base. This latter condition only occurs in the group of $P$. radha and relatives.

\section{Genitalia}

9. Basal part of uncus swollen and globose: (0) yes; (1) no.

Comment. - In the Dundubiini and elsewhere in the Cicadinae the basal part of the uncus is small and little swollen or globose. In the Dundubiaria this is the case in e.g. Meimuna and Orientopsaltria s. str. In most species of Platylomia and Dundubia, however, the basal part of the uncus is large, swollen and globose (Fig. 6).

10. Mediodistal corner of uncus lobes: $(0)$ not produced; (1) produced.

Comment. - The common situation in the Dundubiaria is that the medial margin of the uncus lobes is curved inwards (dorsad), especially close to where the uncus lobes are joined: The mediodistal corner is then rounded (Figs. 72-73) or angular. Alternatively, the mediodistal corner may be produced into a projection that is directed sideways or inwards (Figs. 19-20, 37-38). This projection appears to be unique for the species of the $D$. nagarasingna group.

11. Elongation of uncus lobes: (0) no; (1) yes.

Comment. - In the Dundubiaria the uncus lobes normally are short and do not or hardly extend over the surface enclosed by the anteroventral margin of the pygofer. Alternatively, the uncus lobes are much elongated and do extend over this surface for a considerable distance (Fig. 45). This latter condition is rare.

12. Distal margin of uncus lobes broadly rounded: (0) no; (1) yes.

Comment. - The distal margin of the uncus lobes in the Dundubiaria displays a large variety of shapes. This margin is often more or less straight, truncated, concave (compare Figs. 12, 37) or curved inwards (dorsad), or the uncus lobes are narrowed distally and pointed and sometimes curved; in both cases the margin can be adorned with small rounded, blunt or pointed lobules. Only rarely the uncus lobes are rather flat and broadly rounded at the distal margin.

13. Indentation of lateral margins of uncus lobes: (0) absent; (1) present.

Comment. - The lateral margins of the uncus lobes usually are convex, straight or concave and in the latter case they can have a rounded or more angular emargination. Alternatively a margin can have an indentation. The proximal corner of this indentation is rounded, the distal corner is angular or slightly acute (as in Fig. 51). Such an indentation of the lateral margin is unique for the $D$. jacoona group.

14. Ridge on uncus lobes: (0) absent; (1) present. Comment. - The surface near the medial margins of the uncus lobes is often somewhat depressed. Around this depression there can be a distinct semicircular ridge that extends over the anteromedial part of the basal part of the uncus and runs from one uncus lobe to the other (Figs. 6-7). Other ridge-like structures on the uncus lobes do occur but a similar ridge is found only in the $D$. nagarasingna group.

Relationships in Dundubia including the $\mathrm{D}$. jacoona assemblage

On the basis of the phylogenetic analysis (see Fig. 1) a number of conclusions can be reached. The first is that of the three groups recognized in the $D$. jacoona assemblage only the monophyly of the $D$. spiculata group is not supported by an apomorphy. This group can be recognized by the combination of several plesiomorphic characters: reduction of colour pattern on head and pronotal disc (character 1), posterior margin of pronotal collar narrowly black (character 2), and reduction of markings on lateral part of pronotal collar (character 3). The features that characterize the other two groups and 
that were discussed earlier prove to be apomorphic: the projection on the mediodistal corners of the uncus lobes (character 10) and the connecting ridge on the uncus lobes (character 14) are apomorphies of the $D$. nagarasingna group; the indentation of the lateral margin of the uncus lobes (character 13) is an apomorphy of the D. jacoona group. The elongation of the uncus lobes (character 11 ) is an autapomorphy of $D$. nigripes.

The second conclusion is that the relationships between the groups of the $D$. jacoona assemblage, D. nigripes, and Dundubia s. str. are only partly resolved. The clade formed by the $D$. spiculata group and Dundubia s. str. has two apomorphies: the reduction of the colour pattern on the head and the pronotal disc (character 1) and the reduction of the markings on the lateral part of the pronotal collar (character 3). This clade shares two apomorphies with the D. jacoona group: the presence of darkening near the lateroproximal corner of the operculum (character 7) and the broadly rounded shape of the distal margins of the uncus lobes (character 12). The first character (character 7) is also shared with Orientopsaltria s. str. The relationships between $D$. nigripes, the $D$. nagarasingna group, and the clade formed by the $D$. jacoona group, the D. spiculata group, and Dundubia s. str. will remain unresolved until more information becomes available.

The third conclusion is that the three groups of the $D$. jacoona assemblage, $D$. nigripes, and $D$. vaginata [Dundubia s.str.] form a monophyletic group. This is supported by two apomorphies: the globose postclypeus (character 4) and the absence of markings on the tegmina (character 5). Because of this monophyly the species of the $D$. jacoona assemblage are classified in Dundubia. The $D$. jacoona assemblage as a whole is non-monophyletic, so it is neither advisable nor practical to establish a new taxon to accommodate its species.

\section{Taxonomy}

Description of the $\mathrm{D}$. jacoona assemblage

Diagnosis. - Medium-sized to large cicadas: $\sigma^{\prime}$ : 27.5-45.0 mm; \& : 26.0-40.0 mm. Body of males and females largely unicolorous ochraceous to castaneous brown, head and thorax in some species with castaneous or black markings; posterior margin of pronotal collar always narrowly black. Many species often with some parts on head (anteromedial spot on postclypeus, parts of vertex, ventral parts) and thorax (median area of pronotal disc and large parts of pronotal collar) greenish or paler than main part of body. Operculum unicolorous. Dorsal part of abdomen usually darker than head and thorax, often with dark lateral spots. Legs either with or without dark pattern, when patterned then most extensive on anterior legs. Timbal coverings shorter than broad at base. Basal part of uncus well developed and globose, usually more than twice as broad as long. [It should be noted that living and freshly collected specimens of species described here as ochraceous may well be clear greenish as are the paler parts on the bodies of darker species.]

Head. - Postclypeus in dorsal view swollen, just less than one and a half times to twice as wide as distance between postclypeus and eye, but usually variable within species. Rostrum just reaching beyond anterior margins of hind coxae or little shorter, only in D. oopaga reaching beyond posterior margin of hind coxae.

Thorax. - Broadest part of pronotum broader than head but sometimes only just so. Pronotal disc narrower than head but sometimes only just so; a medial spot immediately in front of pronotal collar often present, posterior margin of pronotal disc occasionally with dark brown to black transverse band, only in D. oopaga with a more extensive distinct black pattern on disc. Pronotal collar broad, median width 0.4-0.6 times the medial length of pronotal disc, always narrowly black on posterior margin and sometimes with brown to black markings on lateral and posterior part of pronotal collar. Mesonotum often with more or less dark paramedian fasciae or with small brown spots immediately anterior of apices of anterior arms of cruciform elevation; some species with more extensive dark pattern but only in $D$. oopaga with black pattern.

Tegmina and wings. - Hyaline or with reticulate brownish pattern between veins in distal and pos- 
terior part of tegmina, occasionally basal veins of second and third apical cells slightly infuscate.

Legs. - Unicolorous ochraceous to brownish or with more or less extensive pattern of dark brown to black markings. Fore femur with two or three anteroventral spines, proximal spine strongest and at about two fifths from base, middle spine at three quarters from base and either strong or rather weak, distal spine smaller than proximal and middle spine but occasionally indistinguishable. Hind tibiae with two anterodorsal spines at about 45$55 \%$ and $75-90 \%$ from base and three ventral spines at 50-60\%, 70-80\%, and 90-95\% from base, most spines about as long as tibial diameter; occasionally hind tibiae with three anterodorsal spines or two or four ventral spines. Spines on fore femora and hind tibiae of same colour as paler parts of legs and often darkened at apex, more extensively so on hind tibiae. Apex of hind tibia with anteroventral comb of about 15-20 brownish spines.

Male operculum. - Operculum with small lateroproximal lobe, constriction at about 0.3-0.4 from base, distal of constriction rather variable in shape, medial margin convex just distal of constriction, near apex either convex, straight, or concave; apex rounded to pointed or even gully-shaped; lateral margin either weakly or strongly convex, sometimes straight or even concave near apex. Surface at base of operculum with concave areas and distal of constriction always to some extent convex and generally following outline of abdomen; lateral margin close to abdomen, operculum in dorsal view generally only visible when part distal of constriction is strongly convex. Operculum reaching from beyond anterior margin of fifth to just beyond posterior margin of eight abdominal segment. Unicolorous or ochraceous to brownish with green, at most darkened at lateroproximal corner into lateral concavity and sometimes elsewhere along the margin.

Abdomen. - Ochraceous to castaneous, in males often with distinct lateral spots, but lateral spots usually less distinct or absent in females or in dark specimens. Abdomen in male just shorter than to 1.4 times as long as head and thorax together, in female about as long as head and thorax together; anteriorly about as wide as mesonotum, in male gradually tapering towards genitalia, in female more suddenly narrowed just anterior of pygofer. Timbal covering of male shorter than its basal width. Male sternite 8 tapering posteriorly and convex in longitudinal direction, surface with long pale or brownish hairs, often interspersed with shorter hairs.

Male genitalia. - Pygofer with lateral lobes rounded; basal lobes little to distinctly developed, sometimes pointed; anteroventral margin with long hairs, hairs in some species continuing anteriorly for some distance on outer surface of pygofer or on surface enclosed by anteroventral margin; basal lobes with hairs either shorter or as long as hairs on anteroventral margin. Outer surface with short hairs, especially on posteroventral and posterior margins, only few hairs on anterior part, where longer hairs are scattered between short ones. Basal part of uncus slightly globose and semicircular. Uncus lobes with medial margins curved inwards; mediodistal corners produced into medial projection in some species; distal margins convex to concave; lateral margins usually straight to slightly convex, more or less parallel to convergent distally, sometimes with emargination or indentation; only in $D$. nigripes uncus lobes long and strongly narrowed at base. Uncus with scattered short hairs on outer surface set more densely along margins of lobes, some strong erect hairs present laterally where uncus lobes and basal part of uncus are joined. Anal valve with triangular lamellae; lamellae dorsally and ventrally set with short hairs and with some long hairs laterally between them.

\section{Key to the males}

Using the key it should be kept in mind that collection specimens now ochraceous to castaneous may have been wholly or partly green when alive. The light-dark pattern should remain largely unaffected by killing.

Most females cannot as yet be identified. with confidence. Possibly relevant characters are given and discussed in the descriptions of the species. 
1 a Uncus lobes long and narrow, almost straight and pointed and without incisions or projections (Figs. 45-46)

D. nigripes

b Uncus lobes not long and narrow; either short with medial projection on mediodistal corners, or broad and long with or without lateral incisions

2 a Uncus lobes with medial margins curved inwards along whole length and forming medial projections that may or may not be hidden under outer surface of uncus lobes (Figs. 6-7, 12-13, 19-27, 37-38)

b Uncus lobes with medial margins curved inwards at bases of lobes only and without projections ... 6

3 a Medial projections of uncus lobes short and hidden under outer surface of uncus lobes (Figs. 37-38)

D. myitkyinensis

b Medial projections of uncus lobes long, clearly projecting from under outer surface of uncus lobes (Figs. 6-7, 12-13, 19-27)

4 a Medial projections of uncus lobes neither two-tipped nor bifurcate (Figs. 6-7); basal lobes of pygofer angularly rounded (Fig. 6) D. feae

b Medial projections of uncus lobes either two-tipped or bifurcate (Figs. 12-13, 19-27); basal lobes of pygofer rounded (Figs. 12, 19) 5

5 a Medial projections of uncus lobes bifurcate with thornlike outgrowths at mediodistal corners of uncus lobes or along projections at small distance from laterodistal corners (Figs. 12-13) D. hainanensis

b Medial projections of uncus lobes either two-tipped or bifurcate with thorn-like outgrowths situated close to apex of projection, shape of apical part of medial projection rather variable (Figs. 19-27) D. nagarasingna

6 a Uncus lobes with lateral margin in ventral view incised, not smoothly emarginate (Figs. 51-52, 58-59, 65-66) ...7

b Uncus lobes with lateral margin in ventral view either emarginate or not, but never incised (Figs. 72-73, 79-80, 86-87)

7 a Body greenish to ochraceous with distinctive black markings on head and thorax (Fig. 61). Rostrum reaching beyond hind coxae. Opercula with rounded apex (Fig. 60). D. oopaga

b Body unicolorous ochraceous to olivaceous or castaneous brown with greenish to ochraceous brown marks on head and thorax, paramedian fasciae on mesonotum indistinct or absent. Rostrum reaching no further than bases of hind coxae. Opercula either slightly angular or rounded at apex (Figs. 53, 67)

8 a Body castaneous brown with greenish to ochraceous brown marks on head and thorax. Opercula with slightly angular apex (Fig. 53). Katepimeral lobe broad and rounded (Fig. 57), sometimes almost angular at apex.
Larger species, length $33 \mathrm{~mm}$ or more ........... D. jacoona

b Body unicolorous ochraceous to olivaceous. Opercula with rounded apex (Fig. 67). Katepimeral lobe narrow (Fig. 71). Smaller species, length $32 \mathrm{~mm}$ or less

D. ayutthaya

9 a Opercula with smoothly rounded apex, tip virtually on longitudinal midline of operculum (Fig. 88). Uncus lobes narrowed towards anterior margin, uncus thus much narrower at distal margins of uncus lobes than at bases of uncus lobes (Fig. 86) D. sinbyudaw

b Opercula with apex either pointed or angular, tip lateral of longitudinal midline of operculum (Figs. 74, 81). Uncus lobes hardly narrowed towards anterior margin, uncus broader or not much narrower at distal margins of uncus lobes than at bases of uncus lobes (Figs. 72, 79) ......... 10

11 a Opercula narrow, distal of constriction almost twice as long as wide; apex acutely pointed or angular (Fig. 74). Uncus lobes not distinctly curved sideways, uncus at distal margins of uncus lobes narrower than at bases of uncus lobes (Fig. 72). D. spiculata

b Opercula broad, distal of constriction almost one and a half times as long as wide, apex angularly rounded (Fig. 81). Uncus lobes usually more or less curved sideways, uncus at distal margins of uncus lobes broader than at bases of uncus lobes or just as broad (Fig. 79)

D. laterocurvata

\section{Descriptions of the species}

Dundubia feae (Distant, 1892) n. comb. (Figs. 2, 6-11)

Cosmopsaltria feae Distant, 1892a: 101; 1892b: xii, 154, pl. XV figs. 20-20b; 1901: 247; 1906a: 98; 1906b: 56; 1912b: 45; Kato, 1932b: 165; Schmidt, 1932: 126; *Kato, 1934: 154; Wu, 1935: 12; Metcalf, 1963a: 548; Overmeer \& Duffels, 1967: 58. Orientopsaltria feae; Kato, 1956: 95, 108; Duffels, 1983: 4, 9; Duffels \& Van der Laan, 1985: 119.

Dundubia longina Distant, 1917b: 319, 320 (n. syn.); Metcalf, 1963a: 531; Overmeer \& Duffels, 1967: 32, 33, 58; Bloem \& Duffels, 1976: 143.

Lectotype designation and synonymy. - According to the description (Distant, 1892a), the type material of $D$. feae was deposited at MSNG but a male from the same series is now deposited at the BMNH. In the MSNG are three males and one female, all bearing the following locality label: 'Carin / Asciuii Ghecù / 1400-1500 m. / L. Fea. III-IV.88.' [printed]. One male bears a second label 'Cosmopsaltria / feæ Dist. / (type)' [Distant's handwriting]; the second male bears a second label 'Cosmopsaltria / Feæ Dist / sp. n.' [handwritten]; the third male bears a second label ' $\mathrm{i}$ Padaun le raccalgono / e mangiano abbrustolite' [handwritten; translated: the Padaung collect them and eat them roasted]. The female bears an additional ' $Q$ ' 


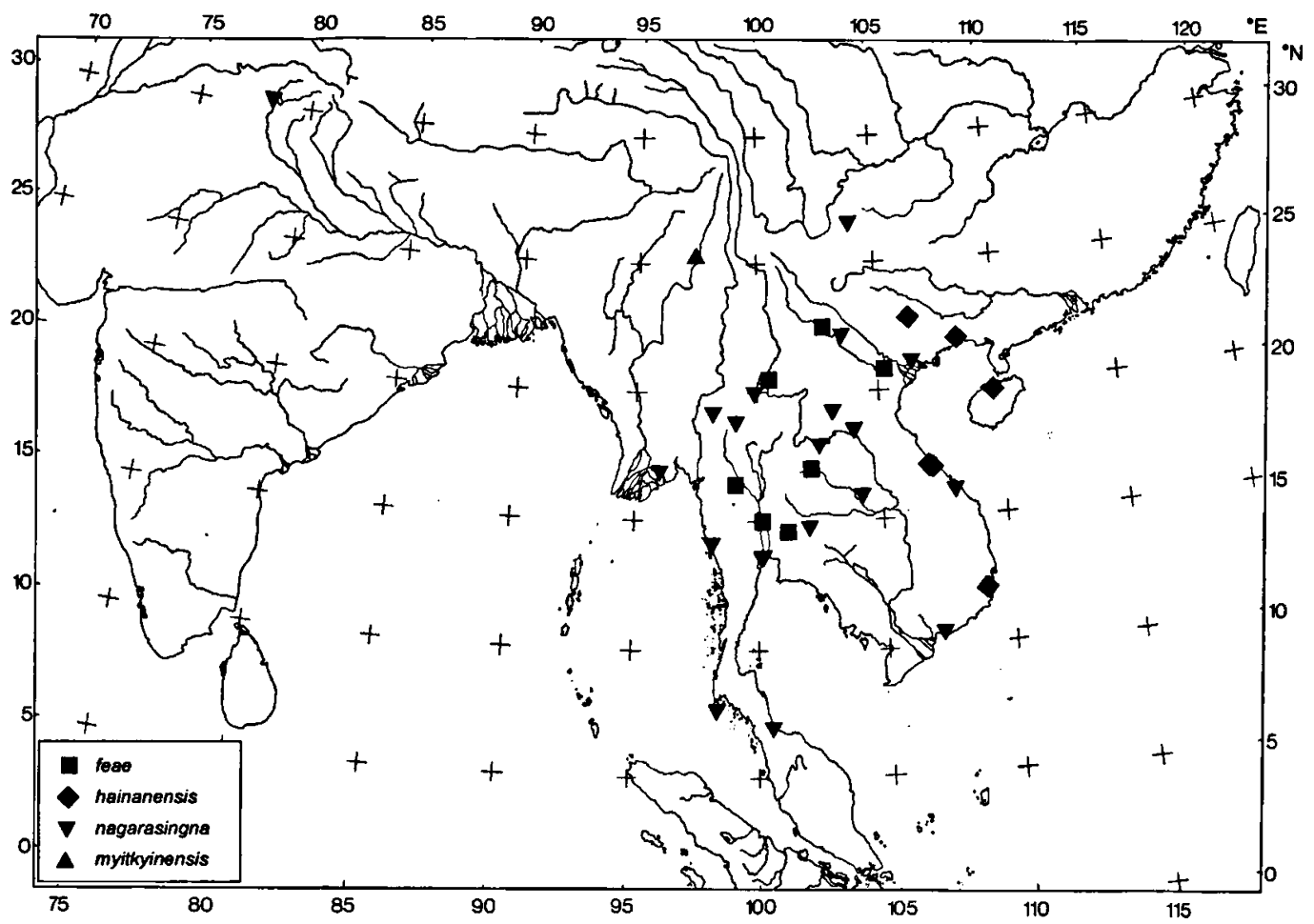

Fig. 2. Localities of Dundubia feae, D. hainanensis, D. nagarasingna, and D. myitkyinensis.

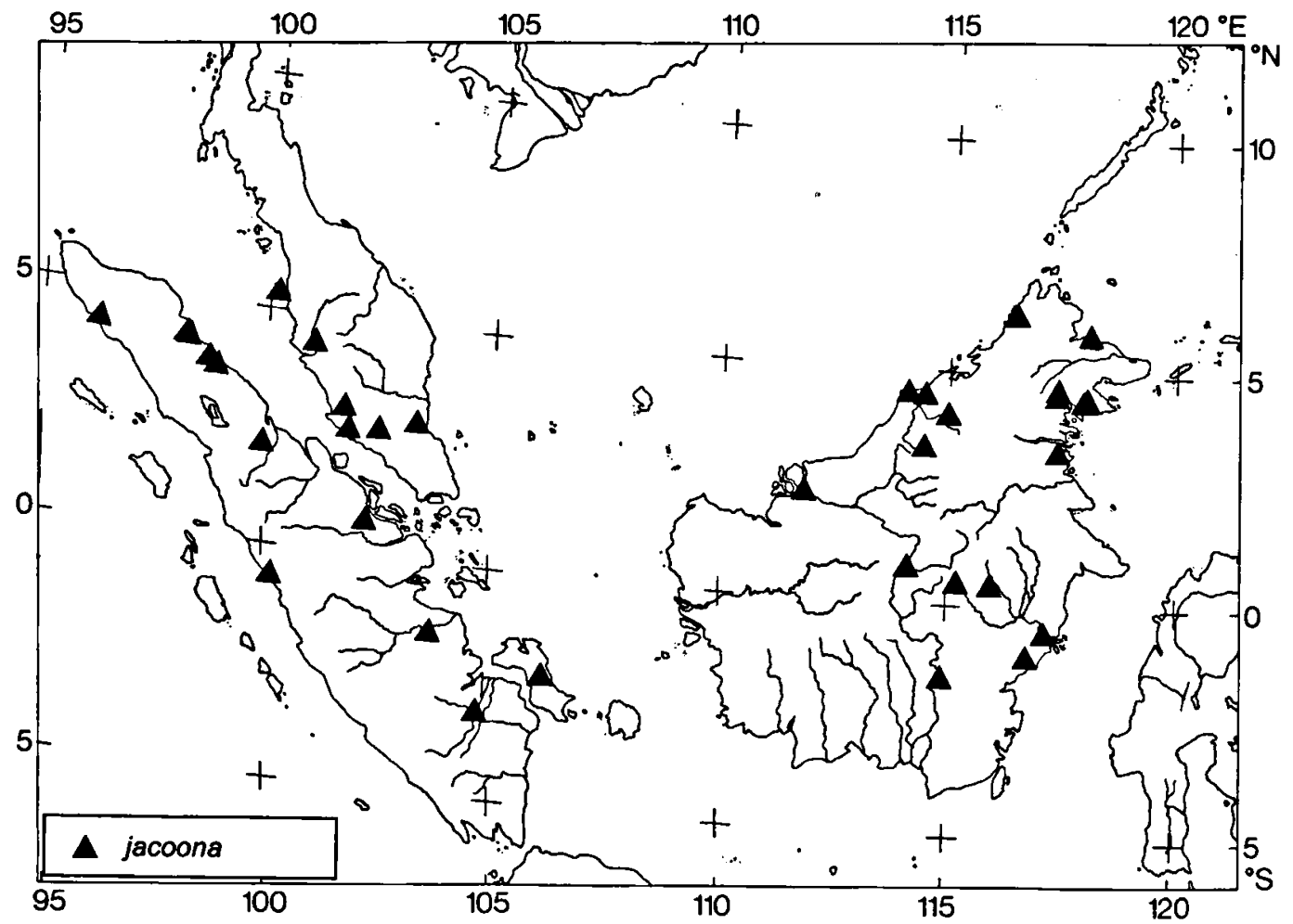

Fig. 3. Localities of Dundubia jacoona. 


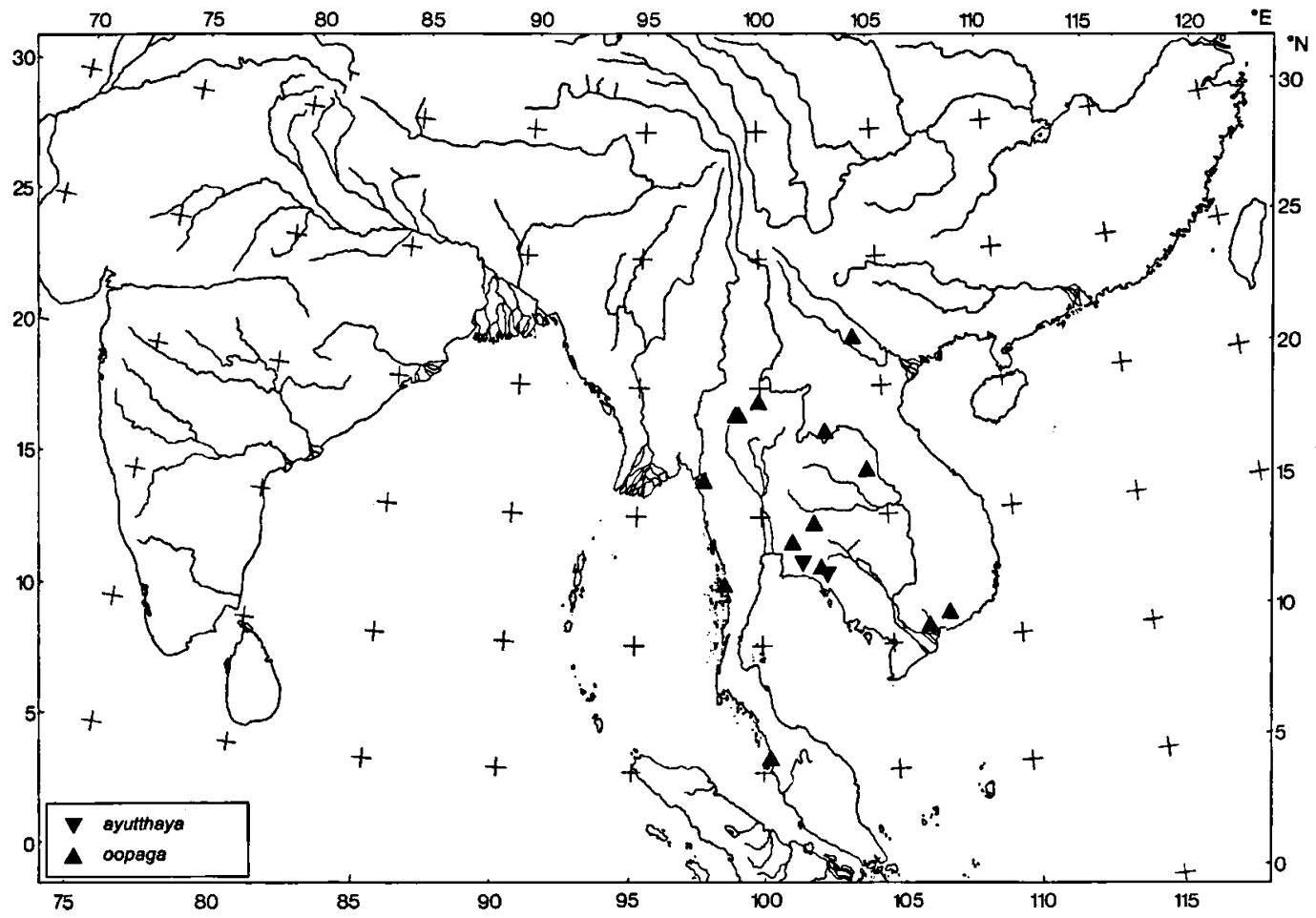

Fig. 4. Localities of Dundubia oopaga and D. ayutthaya.

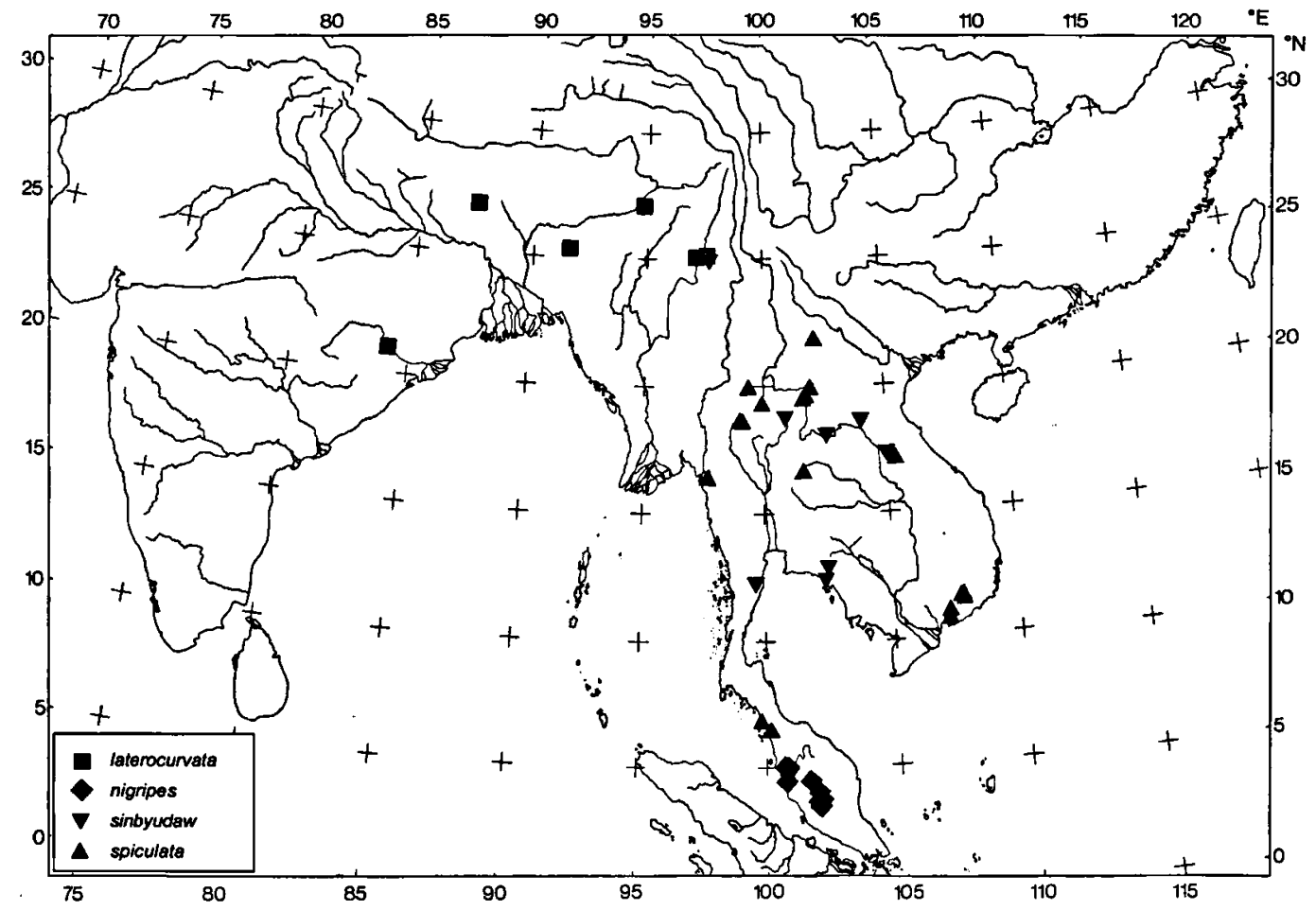

Fig. 5. Localities of Dundubia nigripes, $D$. spiculata, D. laterocurvata, and $D$. sinbyudaw. 

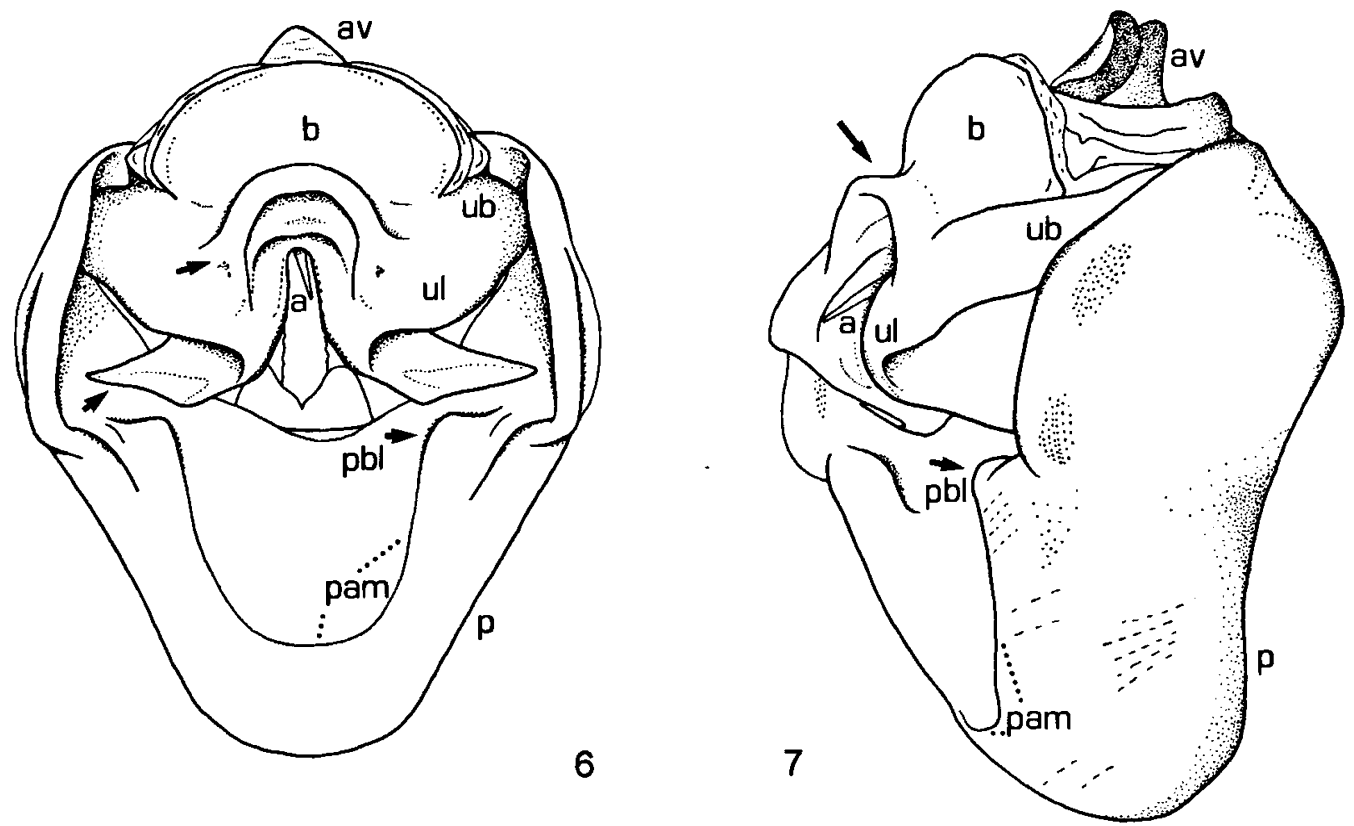

Figs. 6-7. Dundubia feae (Distant, 1892), male, Khao Nang Rum: 6, pygofer and uncus in ventral view; 7, pygofer and uncus in lateroventral view. Legend: $a=$ aedeagus; $a v=$ anal valve; $b=$ basal part uncus; $p=$ pygofer; pam = anteroventral margin pygofer; $p b l$ $=$ basal pygofer lobes; $u b=$ bases of uncus lobes; $u l=$ uncus lobes.

label. No type specimen was designated in the original description. The male labelled as type by Distant from MSNG is herewith designated as lectotype and labelled accordingly. The other two males and the female from MSNG and the male from $\mathrm{BMNH}$ are labelled as paralectotypes.

The description of Dundubia longina neither contained a type designation nor an indication of the number of specimens involved. No further notes about possible type material were consequently published. A single specimen from the type series is a male deposited at the BMNH bearing the following labels: 'Type' [printed on round label with red margin], 'Indo-China. / Tonkin. / R.V. de Salvaza. / 1917-98.' [printed], 'Phong tho / Tonkin / 10 avril 17' [handwritten in pencil on folded label], 'Dundubia / longina / type Dist.' [Distant's handwriting], 'Distant Coll. / 1911-383.' [printed]. This specimen is herewith designated as lectotype (ICZN Recommendation 73F) and is labelled accordingly. A new handwritten label containing the fading data written in pencil on the folded label has been added.

The close resemblance between $D$. feae and $D$. longina was already mentioned by Overmeer \& Duffels (1967) and they indicated that examination of the genitalia would be necessary. Examination of the lectotypes of $D$. feae and $D$. longina showed that the genitalia are identical and that the specimens differ in minor details only. D. feae and D. longina are thus considered to be synonymous.

Material examined. - Vietnam: Hoa Binh, Tonkin, 1919, J. De Cooman \& R. Oberthur, 1 ơ, MNP; Phong Tho, Tonkin, 10.iv.1917, R.V. de Salvaza, o* lectotype Dundubia longina, BMNH.

Laos: Pang Bo, Luang Prabang, 29.iii.1920, R.V. de Salvaza, $1 \sigma^{\circ}, \mathrm{BMNH}$.

Thailand: Hinlap, i, H. Fruhstorfer, $1 \sigma^{\circ, 2}$ \% \&, NHMW; Huaikha Khaeng Wildlife Sanctuary, $16^{\circ} \mathrm{N} 99^{\circ} \mathrm{E}, 27$. ii.1986, 1 ơ, 1 \& , R. Guinnel, ZMA; Khao Nang Rum, Uthai Thani, 400 m, 1.iii.1986, M.G. Allen, 2 ơ $\sigma^{\circ} 1$ ९, BMNH; Muok-Lek [Muaklek], $1000 \mathrm{ft}, \mathrm{i}, \mathrm{H}$. Fruhstorfer, $1 \sigma^{\circ}, 1 \%$, NHMW.

Burma: Asciuii Ghecù, Carin, 1400-1500 m, iii-iv.1888, L. Fea, o* lectotype Cosmopsaltria feae, MSNG; same data, 2 $\sigma^{\circ} \sigma^{\circ}$ and $1 \%$ paralectotypes Cosmopsaltria feae, MSNG; same data, 1 o paralectotype Cosmopsaltria feae, $\mathrm{BMNH}$.

Females probably belonging to this species. - Vietnam: Phong Tho, Tonkin, vi.1917, R.V. de Salvaza, 3 ९ \&, BMNH; rég. de Hoa Binh, Tonkin, 1926, A. de Cooman, 1 \&, MNP.

Thailand: Fang, Chiengmai [Chiang Mai], $500 \mathrm{~m}$, 19.iv.1958, T.C. Maa, 1 \% , BPBM; Huai Kha Khaeng, 400 m, iii.1986, M.G. Allen, 1 \&, BMNH.

Location unknown: Ostindien, 1895, Lebzelter, 1 \&, NHMW.

Remarks. - D. feae is a rather large-sized species with ochraceous brown to dark brown colour. This species can be separated from related species by the shape of the opercula that are very broad on the distal half (Fig. 8) and by the shape of the medial projection of the uncus lobes (Fig. 6). 
Description. - Body brownish to castaneous, posterior parts paler; ventral parts of body paler than dorsal parts; head and thorax with a lighter pattern, paramedian fasciae on mesonotum often present. Usually no pair of brown spots at posterior margin of lateral lobes of pronotal disc.

Head: Postclypeus castaneous brown but lighter lateroventral of anteromedial spot; anteromedial spot ochraceous and area anterior of frontoclypeal suture brownish. Anteclypeus castaneous, lighter on median line and sometimes along lateral margin. Vertex brown but darker on vertex lobes except along eye margin; area of ocelli castaneous, sometimes connected with darker part on vertex lobes or extending posteriorly and enclosing paler medial spot on posterior margin of vertex. Suture between vertex lobe and supra-antennal plate distinct, merging with longitudinal groove running along lateral part of frontoclypeal suture and between eye and lateral ocellus. Frontoclypeal suture trapezoid, medial part wider than distance between lateral margins of lateral ocelli. Rostrum ochraceous, blackened at apex, reaching middle of hind coxae.

Thorax: Pronotum slightly to distinctly broader than head. Pronotal disc castaneous brown with faint indication of darker central fasciae, anterior margin and median area ochraceous brown or sometimes more olivaceous; medial spot in front of pronotal collar distinct. Pronotal collar ochraceous brown to olivaceous with black posterior margin; anterolateral parts with large brown spots that can be divided into two smaller spots; usually no pair of brown spots at posterior margin of lateral lobes of disc but when present indistinct; anterior corner with short pointed lateral tooth, posterior corner smoothly rounded. Mesonotum and cruciform elevation castaneous brown, median area on posterior half and lateral areas of mesonotal disc and apical half of anterior arms of cruciform elevation often somewhat darker. Katepimeral lobe (Fig. 11) shorter than or about as long as basal width; dorsal margin convex especially towards apex; apex angular to narrowly rounded; ventral margin concave to almost straight. Surface of katepimeral lobe flat to slightly concave on dorsal half, covered with short hairs and waxy coating and with some scattered long hairs; hairs on mar- gins somewhat longer, especially on ventral margin. Apex of katepimeral lobe just reaching base of operculum or shorter.

Tegmina and wings: Tegmina hyaline; basal cell with pale infuscation. Veins of tegmen dark brown but subcosta + radial vein, base of medial vein, contact zone between radial and medial veins, second cubital vein, and anal veins paler. Wings hyaline; veins ochraceous to brownish, first cubital vein and veins in distal part of wing darker.

Legs: Fore femora with dorsal surface brown to dark brown, distally with dark band just before apex, posteroventral stripe dark; fore tibiae dark brown with ochraceous dorsal stripe on proximal half, when extensively darkened then extending to dorsal part near apex; fore tarsi brownish. Mid femora ochraceous, anterior surface with indistinct brown longitudinal stripe, anterodorsal and posterodorsal stripes either present or absent, all stripes sometimes connected by dorsal band just before apex; mid tibiae ochraceous, darkened dorsally and ventrally and when extensively darkened then stripes joining near apex, apex itself ochraceous; mid tarsi brown. Hind legs ochraceous, only hind tibiae darkened ventrally on distal half. Fore femur with middle spine shorter and more sharply pointed than proximal spine; distal spine small and blunt, indistinct; gap between middle and distal spines broad and very shallow. Hind tibia exceptionally with fourth anteroventral spine at about $40 \%$ from base.

Male. Operculum (Fig. 8): Very long, reaching from just beyond anterior margin of seventh abdominal segment to halfway eighth abdominal segment, 2.6-2.9 times as long as maximum width distal of constriction; ochraceous but sometimes with greenish tinge on distal part, lateroproximal corner darkened. Medial margin concave near base, distal of constriction first convex, but almost straight towards apex. Apex truncate to angularly rounded, when truncate distal margin straight to weakly convex and mediodistal and laterodistal corners rounded (Fig. 8); tip when distinct medial of longitudinal midline of operculum. Lateral margin concave at level of timbal covering and somewhat beyond, distal of constriction first convex, weakly convex to almost straight towards apex, 


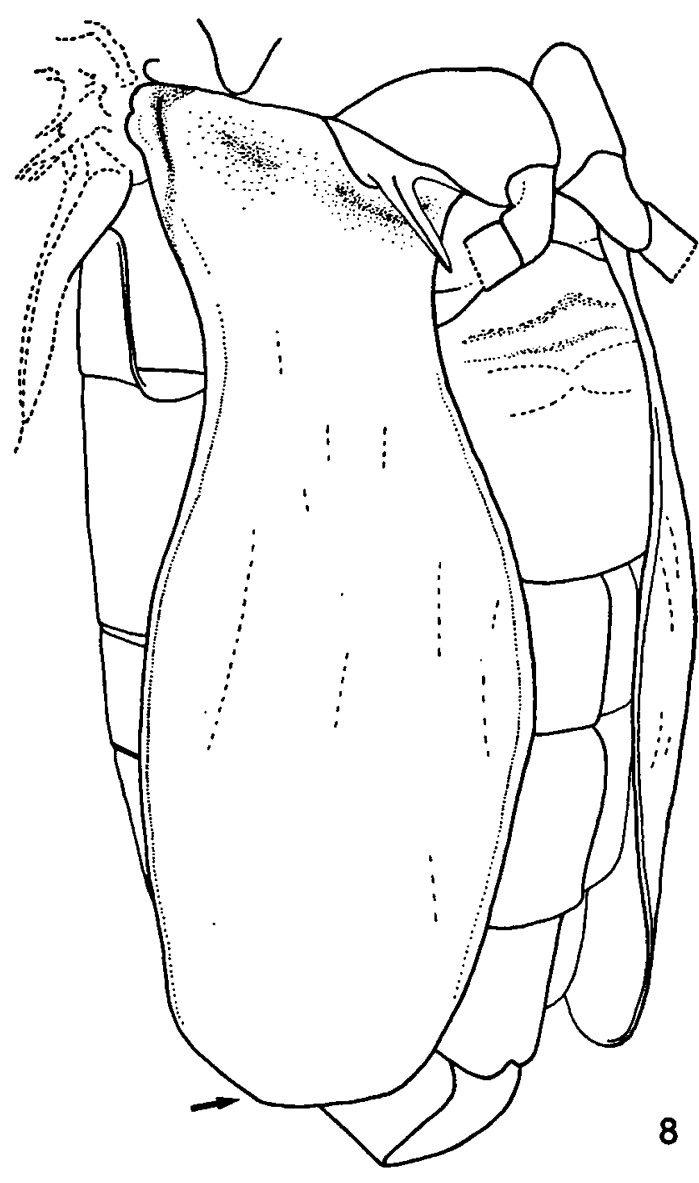

from base onwards almost parallel to slightly convergent with medial margin. Constriction at $0.2-$ 0.3 of length of operculum, medial concavity less deep than lateral concavity, broadest part of operculum distal of constriction 1.5-1.7 times as wide as minimum width in constriction. Distance between opercula at constrictions 1.2-1.4 (1.6) times as wide as minimum width in constriction. Opercula at point of closest approximation separated for a distance of 0.5-0.6 times maximum width between opercula at constrictions. Surface of operculum convex distal of constriction, flattening distally when apex is truncated, especially at mediodistal corner, often with transverse undulations in area of flattening; mediodistal corner sometimes slightly upturned; less convex when apex is more angular or gouge-shaped at apex when apex is produced; operculum curved around abdomen at lateral margin.
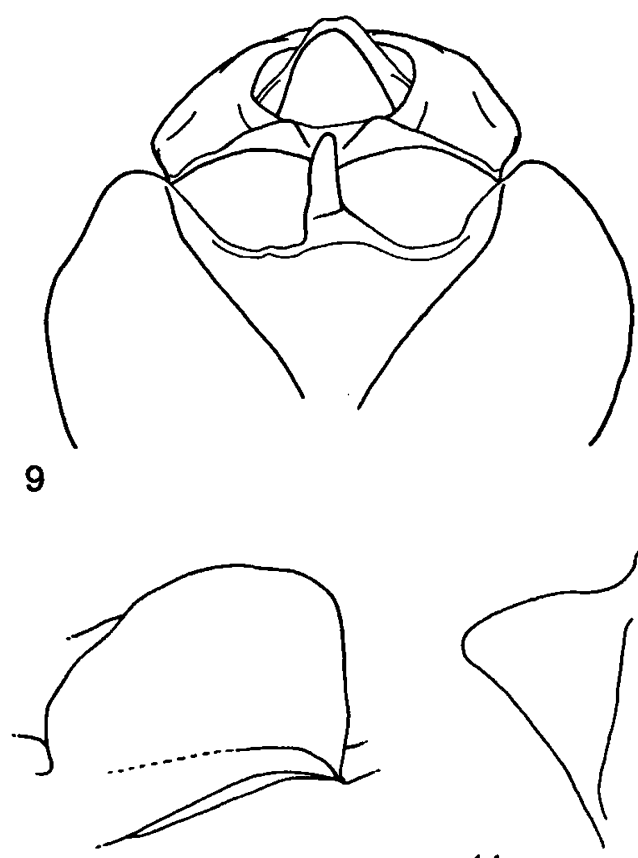

10

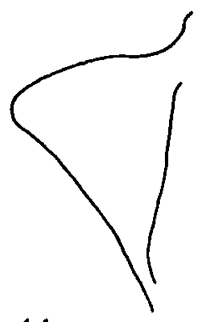

11

Figs. 8-11. Dundubia feae (Distant, 1892), male: 8, right operculum in lateroventral view, Khao Nang Rum; 9, pygofer in dorsal view, Pang Bo; 10, right timbal covering, Khao Nang Rum; 11, right katepimeral lobe, Hoa Binh.

Abdomen: Length 1.0-1.2 times that of head and thorax together. Dorsal part of tergites brown, posterior tergites somewhat darker; sternites and ventral parts of tergites ochraceous brown. Tergites 35 with darker brown lateral spots. Posterior margins of tergites 4-7 with short dark spinules, those on tergite 4 fewer and shorter than on other tergites. Timbal covering (Fig. 10) brownish but slightly darker laterally, about 1.3 times as wide as long; medial margin immediately curved laterad; mediodistal corner and distal margin broadly rounded; laterodistal corner rounded, lateral margin slightly convex to almost straight. Sternite 7 with shallow, rounded posteromedial emargination.

Genitalia (Figs. 6-7, 9): Ochraceous brown but dorsal part of pygofer and posterior margin of basal part of uncus more brownish to castaneous. Basal pygofer lobes angular, well separated from 
lateral margin of pygofer (Fig. 6); hairs on anteroventral margin and basal lobes long, those on basal lobes shorter than those on margin, hairs continuing on surface enclosed by anteroventral margin and for short distance on pygofer surface anterior of medial part of anteroventral margin. Basal part of uncus globose, broad and almost semicircular (Figs. 6-7), near bases of uncus lobes with occasional short erect hairs. Uncus lobes very short and raised compared to basal part of uncus (Fig. 7), connected by semicircular rim around aedeagal opening, rim ending well before distal margin (Figs. 6-7); medial margin and mediodistal corner strongly curved inwards and produced into long tapering, sideways directed, thick lobe (Fig. 6); distance between apices of lobes on medial margins much more than to about equal to distance between anterolateral corners; distal margin concave or almost straight; laterodistal corner broadly rounded; lateral margins weakly convex and convergent from base; uncus lobes with few long erect hairs lateral of rim, otherwise on flat surfaces with shorter erect hairs; hairs on inner (dorsal) surface and on lobe on medial margin somewhat longer.

Female. Operculum brownish, darker basally and along medial margin, just reaching beyond base of sternite 3 , only little curved around abdomen laterally. Lateral margin distal of lateroproximal lobe weakly convex; laterodistal corner angularly rounded; distal margin weakly convex; mediodistal corner broadly rounded; medial margin short and convex; lateral and medial margin of each operculum convergent from base.

Abdomen: Length 0.8-0.9 times that of head and thorax together. Dorsal part of tergites castaneous brown; sternites and ventral parts of tergites lighter. Tergites 3-6 near lateral margin with darker spots. Posterior margin of tergite 4 with some short and slender dark spines medially; posterior margin of tergites 5-7 with more numerous and longer spines; posterior margin of tergite 8 with scattered spines medially. Sternite 7 with a rounded posteromedial emargination.

Genitalia: Dorsal part of pygofer and distal part of ovipositor sheath almost castaneous, remainder brownish. Dorsal margin of pygofer in lateral view slightly concave, ventral margin slightly convex. Ovipositor sheath reaching just beyond apex of caudodorsal beak; anal valve not reaching as far as caudodorsal beak.

Measurements in mm $\left(\sigma^{\circ}: \mathrm{n}=5 ; \%: \mathrm{n}=3\right)$. - Body length: $\sigma^{\circ}$ : 37.5-44.5 (41.2 \pm 2.8$)$, $Q$ : $35.5-40.0(38.3 \pm 1.9)$; head width: or: $12.2-13.9(13.0 \pm 0.6)$, ᄋ : 13.0-14.8 (13.9 \pm 0.6$)$; maximum pronotum width: $\sigma^{\prime \prime}: 12.3-14.4(13.4 \pm 0.7), \%$ : 13.4-15.1 (14.4 $\pm 0.7)$; tegmen length: $\sigma^{\prime:}: 45.0-51.5(48.3 \pm 2.0)$, $९: 47.5-51.5$ $(50.0 \pm 1.7)$.

Distribution (Fig. 2). - D. feae is recorded from Burma, Laos, Thailand, and Vietnam. Records from Jiangsu in China (Schmidt, 1932; Wu, 1935) could not be confirmed.

Dundubia hainanensis (Distant, 1901) n. comb. (Figs. 2, 12-18)

Cosmopsaltria hainanensis Distant, 1901: 247; Kirkaldy, 1909 181.

Platylomia hainanensis; Distant, 1906b: 61; 1912b: 49; Kato, 1932a: 1; 1932b: 166; Schmidt, 1932: 126; *Chen, 1933: 18; *Kato, 1934: 155, pl. 62 fig. 20; Wu, 1935: 13; *Kato, 1938: 10; Kato, 1940a: 18; Liu, 1940: 90; Kato, 1956: 47, 96, 121; Metcalf, 1963b: 619; Duffels \& Van der Laan, 1985: 120.

Dundubia bifasciata Liu, 1940: 88, pl. 5 fig. 24 (n. syn.); Kato, 1956: 95, 118; Metcalf, 1963a: 528; Overmeer \& Duffels, 1967: 32, 33, 55; Liu, 1978: 110, 111, 112, pl. 5 fig. 24.

Not: Dundubia bifasciata; Ishihara, 1961: 225, pl. 1 fig. 1 (see D. nagarasingna and below under Distribution).

Synonymy. - From Distant's wording (Distant, 1901: 'Since this description was written my own collection contains a second example, ... [p. 247]) it can be deduced that the original description was based on a single specimen which must thus be treated as the holotype. The specimen at the BMNH labelled as type has the following labels: 'Type' [printed on round label with red margin], 'Hainam [sic!] / W.R.O. Grant / 99-283', 'hainanensis / Dist. [Distant's handwriting]. These labels do not correspond with the information given in the description. However, the accession number on the locality label refers to an accession book at the BMNH (Zoological Accession Insecta Volume VI 1894-1900) which states that the material in question was collected at Five Finger Mountains, Hainan by Whitehead and presented to the BMNH by Grant. There is no doubt that this specimen is the holotype.

Examination of the holotype of $D$. hainanensis and the paratype of Dundubia bifasciata has shown that the genitalia are identical in structure and that they otherwise differ in minor details only. $D$. hainanensis and $D$. bifasciata are thus considered to be synonymous. Z. Lei (in lit., 1.vii.1995) also considered them to be synonymous but he did not state whether he had examined any type material. 

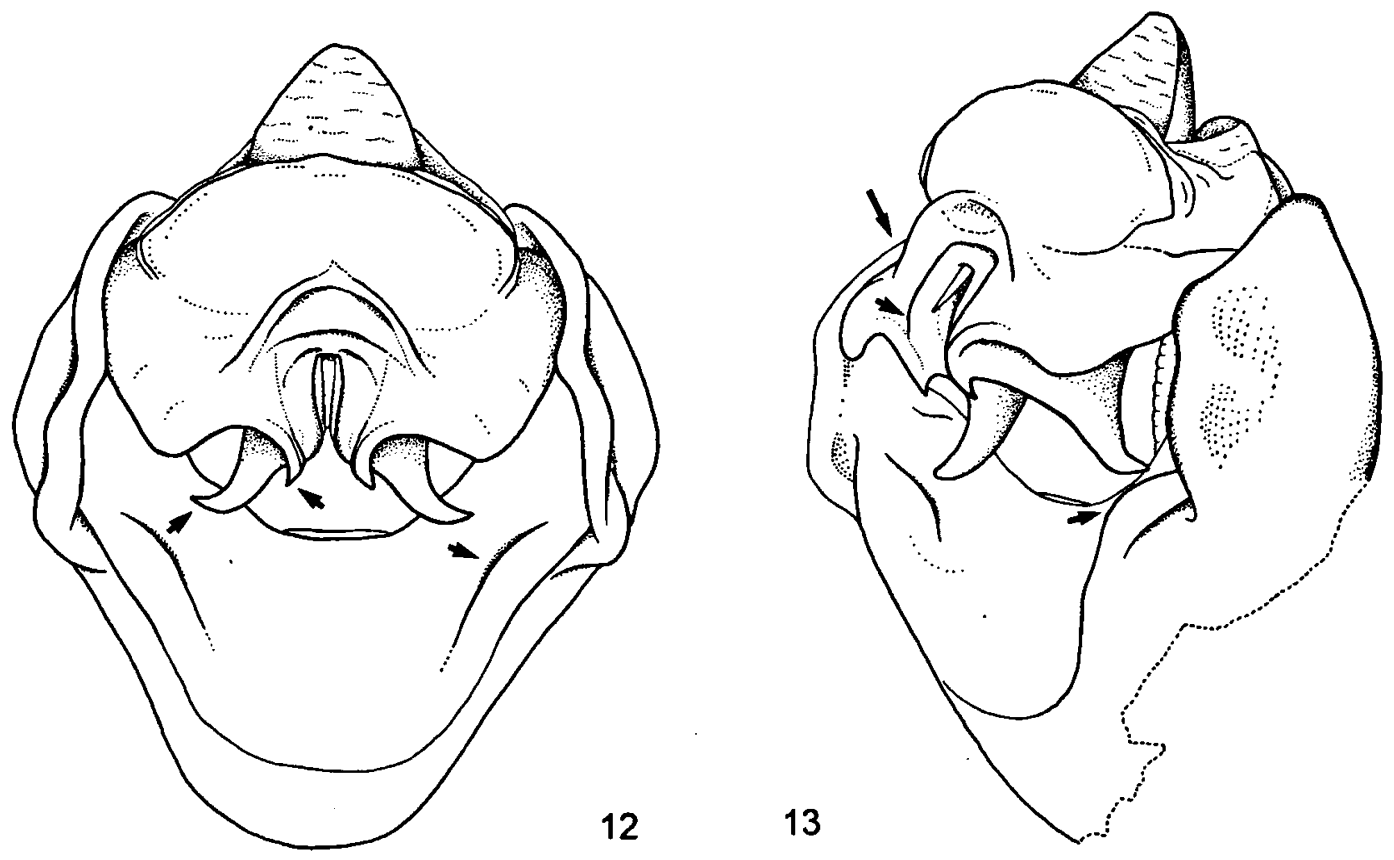

Figs. 12-13. Dundubia hainanensis (Distant, 1901), male: 12, pygofer and uncus in ventral view, Fanyang; 13, pygofer and uncus in lateroventral view, Fanyang.

Material examined. - China: Fanyang, Hainan, 5.iv.1936, G.

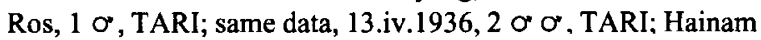
[typographical error for Hainan], holotype ơ Cosmopsaltria hainanensis, BMNH; Hainan Island, 2 o $\sigma, 1$ \%, BMNH; Hainan, 26.viii.1934, Hainan Exp., 1 o, CUIC; Yellow Sea, Hainan, $1 \sigma^{*}, 1$ \& , CUIC; Yua... [remainder illegible], Hainan, 4.iv.1936, G. Ros, $1 \sigma^{\prime}$, TARI; Yungshien, Kwangsi [Guangxi], v.1933, G. Liu, paratype ơ Dundubia bifasciata, MCZ.

Vietnam: An-Ninh, près Quang-Tri, M. Maunier, 1921, 1 \%, MNP; Ba Be National Park, Cao Bang, 14-23.v.1995, D. Currie, B. Hubley \& J. Swann, 1 \&, ROME; Eua Tung, Aman [typographical error for Annam], iii.iv.1928, 1 O", SEM; Monkay [Mong Cai], 1894, Brocars, 1 \%, BMNH; Env. de Quang-Tri, Prov. de Quang-Tri, Annam, Jabouille, 1923, 2 $\sigma^{\circ} \sigma^{\circ}, 1$ \%, MNP; Haut Tonkin, Reinhart, $2 \sigma^{\circ} \sigma^{\circ}, \mathrm{MNP}$; Quantri [Quang Tri], Annam, $1 \sigma^{*}, 1$ \%, BMNH; Region de Bai Troi, Prov. de Quang-Tri, Annam, Jabouille, 1923, 1 \%, MNP.

Remarks. - D. hainanensis is a rather large-sized species with ochraceous brown to brown colour. This species has long opercula that are narrowed near the apex (Figs. 14-15). The medial projection of the uncus lobes is bi-apical but the two spines are well separated from each other (Figs. 12-13).

Description. - Body brownish above, abdomen more castaneous on posterior segments, ventral parts often lighter.
Head: Postclypeus ochraceous brown with medial part ventral of anteromedial spot and parts between ridges darker, anteromedial spot more yellowish. Anteclypeus brown with lighter median fascia and margins. Vertex brownish with area around ocelli and anterior margins of vertex lobes slightly darker. Head otherwise brownish. Suture between vertex lobes and supra-antennal plates shallow to distinct and merged with longitudinal groove running along lateral part of frontoclypeal suture and between eye and lateral ocellus. Frontoclypeal suture with medial part wider than distance between lateral margins of lateral ocelli and almost straight, medial parts with slight to distinct bends. Rostrum brownish, almost black at apex, just reaching between bases of hind coxae.

Thorax: Pronotum broader than head, usually also at level of lateral teeth of pronotal collar. Pronotal disc brown, paramedian and lateral lobes sometimes darker; anterior margin and median part more ochraceous brown, sometimes with greenish tinge. Medial spot immediately in front of pronotal collar small and distinct to almost imperceptible. Pronotal collar somewhat lighter than pronotal disc and sometimes with greenish tinge; 
three pairs of brownish spots, one near anterior margins of collar, one in middle of lateral part, and one on posterior margin of lateral lobes of disc; these spots sometimes almost imperceptible. Anterolateral part of pronotal collar rather narrow, lateral margin almost straight and lateral tooth absent or lateral margin somewhat concave and lateral tooth blunt but distinct; posterior corner broad and smoothly rounded. Mesonotum brownish but slightly more castaneous on posterior parts, paramedian fasciae narrow and dark. Katepimeral lobe (Fig. 18) triangular; dorsal margin slightly concave to almost straight; apex narrowly rounded; ventral margin slightly concave to almost straight. Surface of katepimeral lobe curved towards mesonotum, sometimes apex slightly curved outwards again. Apex of katepimeral lobe just reaching base of operculum.

Tegmina and wings: Hyaline, sometimes with indistinct brownish reticulation visible between veins in distal part; basal cell hyaline or with slight pale infuscation; exceptionally basal veins of second and third apical cells almost imperceptibly infuscate. Veins of tegmen brownish with costa and second anal vein blackish to dark brown with subcosta + radial vein, base of medial vein, contact zone between radial and medial veins, second cubital vein and first anal vein paler. Wings hyaline; veins brownish to dark brownish; medial vein, cubital veins, and first anal vein paler.

Legs: Fore femora brownish with darker brownish ring just before apex and with darker spot at base of proximal spine; fore tibiae very dark brown with a light brown anterodorsal stripe from base onwards for two thirds of their length; fore tarsi dark brown. Mid femora ochraceous to light brownish; mid tibiae darker on dorsal surface and at apex; mid tarsi dark brown. Hind femora ochraceous to brownish; hind tibiae darkened at apex except on dorsal surface; hind tarsi ochraceous. Fore femur with proximal spine slightly longer than middle spine and somewhat pointed; middle spine narrowly triangular and pointed; distal spine very short but distinct; gap between middle and distal spines shallow and broad.

Male. Operculum (Figs. 14-15): Long and distal part rather variable in shape, reaching from just beyond posterior margin of seventh abdominal segment to just beyond posterior margin of eighth abdominal segment, 2.8-3.7 times as long as maximum width distal of constriction; brownish. Medial margin concave near base, concave area long and reaching almost halfway sternite 3 , then first convex but towards apex either almost straight (Fig. 14), weakly convex or slightly concave (Fig. 15) for some distance; apex narrowed towards tip and rounded to angularly rounded, or apex broad and distal margin almost straight with mediodistal and laterodistal corners rounded; lateral margin concave at level of timbal covering, concave area reaching almost halfway tergite 3 , margin just distal of constriction convex and towards apex either straight, convex or weakly convex and slightly concave for some distance. Constriction at 0.2-0.3 of length of operculum, medial concavity very shallow and lateral concavity about twice as deep, broadest point of operculum distal of constriction 1.4-1.8 times as wide as narrowest part in constriction. Distance between opercula at constrictions 1.2-1.7 times as wide as minimum width in constriction. Opercula at point of closest approximation separated for a distance of 0.4-0.7 times maximum width between opercula at constrictions. Opercula curved towards abdomen, surface of operculum distal of constriction convex but almost flat near apex.

Abdomen: Length 1.1-1.3 times that of head and thorax together. Dorsal part of tergites brownish but posterior margins of tergites 3-7 and whole of tergite 8 castaneous, sternites and ventral parts of tergites lighter. Tergites 3-7 with lateral spots though spots not very pronounced. Tergites 5-7 with short dark spines on posterior margin, more numerous and somewhat longer posteriorly. Timbal covering (Fig. 17) brownish, large and sometimes very broad, 1.1-1.4 times as wide as long, not always broadest at base; medial margin rather short, either almost straight or convex; mediodistal corner rounded; distal margin convex, laterodistal corner rounded but not as broadly as mediodistal corner; lateral margin straight, sometimes concave for short distance. Sternite 7 with shallow, angular posteromedial emargination.

Genitalia (Figs. 12-13, 16): Brownish, only pygofer slightly darker dorsally. Basal pygofer 


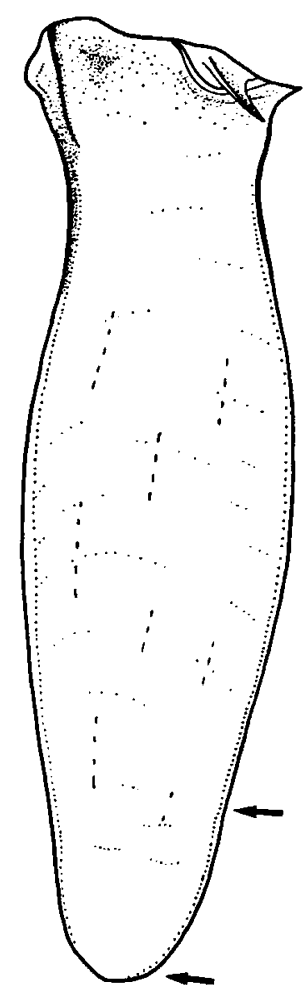

14

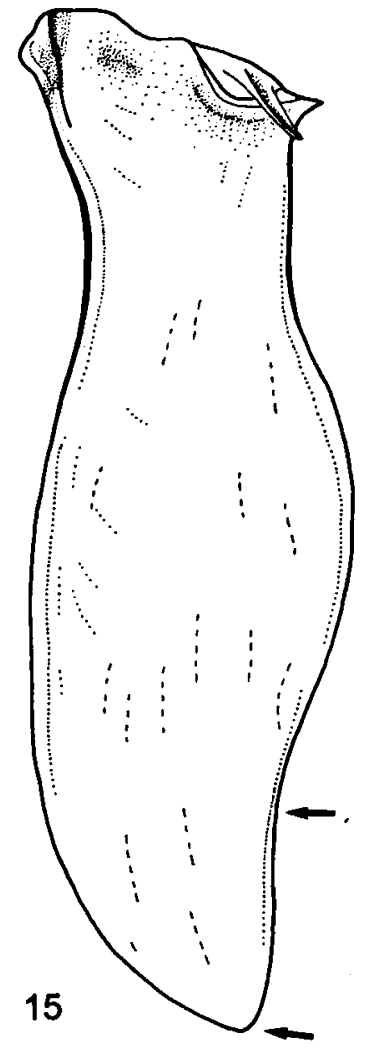

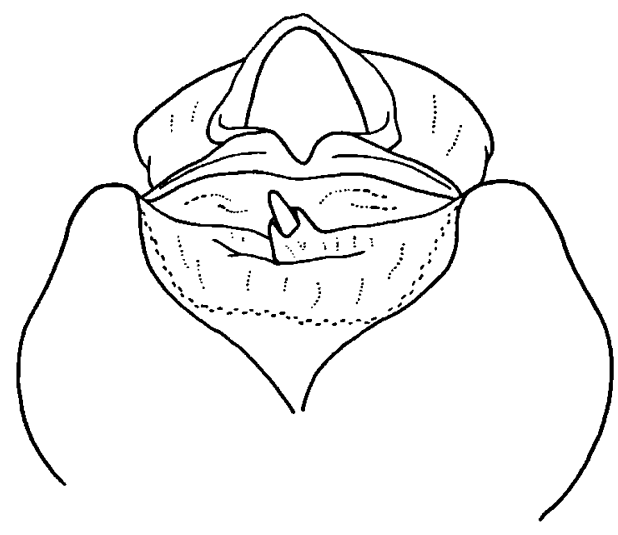

16
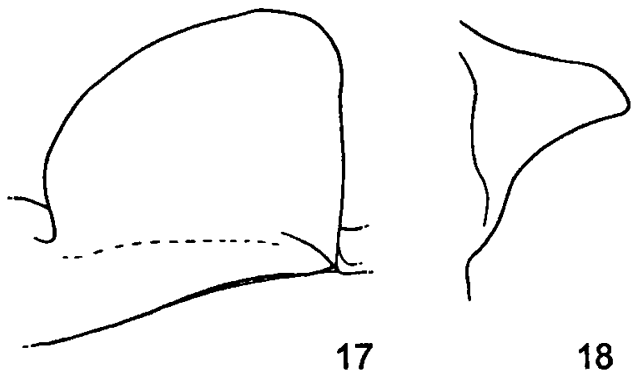

18

Figs. 14-18. Dundubia hainanensis (Distant, 1901), male: 14, right operculum in lateroventral view, Fanyang; 15, id., Quang Tri; 16, pygofer in dorsal view, Fanyang; 17, right timbal covering, Eua Tung; 18, right katepimeral lobe, Fanyang.

lobes formed by swollen continuation of anteroventral margin, smoothly rounded (Fig. 12); hairs on anteroventral margin and basal lobes long, those on basal lobes even slightly longer than those on margin but virtually no hairs on pygofer surface anterior of anteroventral margin. Basal part of uncus globose, broad and almost semicircular, near bases of uncus lobes with occasional short erect hairs. Uncus lobes very short and raised compared to basal part of uncus (Fig. 13), connected by rim around aedeagal opening with medial part of rim extending onto basal part of uncus and almost continuing to distal margin (Figs. 12-13); medial margin strongly curved inwards and produced into long, tapering, sideways directed lobe (Figs. 1213); distance between apices of lobes on medial margins about equal to distance between anterolateral corners; mediodistal corner produced into short inwards (dorsally) directed, pointed projec- tion (Figs. 12-13); distal margin concave; laterodistal corner rounded; lateral margin smooth and weakly convex; lateral margins of uncus lobes sometimes with short thick erect hairs, surface otherwise covered with sparse, thin erect hairs which are shortest on outer (ventral) surface.

Female. Operculum ochraceous brown, darkened at lateroproximal corner, just reaching from just beyond anterior margin to halfway sternite 3 , only little curved around abdomen laterally. Lateral margin distal of lateroproximal lobe almost straight; laterodistal corner usually angular, sometimes angularly rounded; distal margin weakly convex and often straight near laterodistal corner; mediodistal corner broadly rounded; medial margin short and weakly convex; lateral and medial margins of operculum convergent from base.

Abdomen: About 0.9 times as long as head and 
thorax together. Dorsal part of tergites dark brownish, little paler on anterior segments; sternites and ventral parts of tergites ochraceous brown to brownish. Tergites 3-6 near lateral margin with darker spots that may be very indistinct or completely covered by dense cover of short silvery hairs. Posterior margin of tergites 4-7 with numerous slender dark spines, those on tergite 4 fewer in number than on tergites 5-7; posterior margin of tergite 8 with scattered spines medially. Tergite 8 heavily grey tomentose. Sternite 7 with a rounded posteromedial emargination.

Genitalia: Dorsal part of pygofer and distal part of ovipositor sheath brown to dark brown, especially around base of caudodorsal beak; remainder ochraceous brown. Dorsal margin of pygofer in lateral view slightly concave, ventral margin slightly convex. Ovipositor sheath reaching about as far as apex of caudodorsal beak; anal valve not reaching as far as caudodorsal beak.

Measurements in mm ( $\left.\sigma^{*}: \mathrm{n}=5\right)$. - Body length: $\sigma^{\prime \prime}: 40.0-45.0$ $(42.8 \pm 2.0)$, $\%: 34.0-39.0(37.5 \pm 1.8)(n=4)$; head width: $\sigma^{\circ}$ : 11.9-14.1 (13.1 \pm 0.8$)$, : $12.4-13.4(13.1 \pm 0.4)(n=3)$; maximum pronotum width: $\sigma^{\prime \prime}: 12.2-14.4(13.8 \pm 0.8)$, $Q: 10.7-11.8$ (11.4 \pm 0.4$)(n=4)$; tegmen length: $\sigma^{\prime}: 42.5-51.5(47.1 \pm 2.7)$, Q : 42.5-49.0 $(46.5 \pm 2.0)(n=4)$.

Distribution (Fig. 2). - D. hainanensis is only recorded from Vietnam and China (including Hainan). Records from Zhejiang in China (Chen, 1933*) and from Japan (Metcalf, 1963b) could not be confirmed. The record from Japan by Metcalf was ascribed to Kato (1934*) but this may be based on a misinterpretation or on a wrong translation of Kato's paper. The record by Ishihara (1961) could not be confirmed either. The illustration of the specimen (Ishihara, 1961: pl. 1 fig. 1) resembles $D$. nagarasingna rather than $D$. hainanensis.

\section{Dundubia nagarasingna Distant, 1881}

(Figs. 2, 19-36)

Dundubia nagarasingna Distant, 1881: 635; Atkinson, 1884: 225; 1886: 164.

Cosmopsaltria nagarasingna; Distant, 1889: 44, pl. IV figs. 1414b; 1892b: xii.
Platylomia nagarasingna; Distant, 1906a: 103; 1906b: 60; 1912b: 48; 1917a: 101; *Kato, 1940b: 3; 1941: 3; Kato, 1956: 121; Metcalf, 1963b: 622; Gogala, 1995: 104, 111, figs. 3a-b. Platylomia nagalasingna [sic!]: Kato, 1932b: 166, pl. XXI fig. 8. Dundubia helena Distant, 1912a: 641 (n. syn.); 1912b: 43; 1916: 4; Metcalf, 1963a: 529; Overmeer \& Duffels, 1967: 31, 33, 57, fig. 25; Duffels \& Van der Laan, 1985: 116.

Cosmopsaltria fratercula Distant, 1912b: 44 (n. syn.); 1917a: 101; Moulton, 1923: 89; Schmidt, 1932: 126; *Kato, 1934: 154; Metcalf, 1963a: 548.

Orientopsaltria fratercula; Kato, 1956: 121; Duffels, 1983: 9.

Platylomia sp.; Gogala, 1995: 104, 111, figs. 4a-b.

?Dundubia bifasciata; Ishihara, 1961: 225, pl. 1 fig. 1 .

Lectotype designations and synonymy. - In the descriptions of Dundubia nagarasingna, D. helena, and Cosmopsaltria fratercula no holotypes were designated and no numbers of specimens upon which the descriptions were based were mentioned. Specimens belonging to the type series of each of the three species should thus be considered syntypes and lectotypes have to be designated (ICZN Recommendation 73F).

The type series of $D$. nagarasingna at the BMNH consists of two males with the following labels: 'N.W. Burmah' [handwritten], 'nagarasingna / Dist.' [Distant's handwriting], 'Distant Coll. / 1911-383.' [printed]. One male with dissected genitalia bears a label 'Type' [printed in round label with red margin] but this does not constitute a valid type (neither holotype nor lectotype) designation. The specimen already bearing the 'Type' label is herewith designated as the lectotype and labelled accordingly. The other male is labelled as paralectotype.

The type material of $D$. helena at the BMNH apparently consists of a single male with the following labels: 'Type' [printed in round label with red margin], 'Dehra Dun' [typewritten], '1414' [printed], 'Dundubia / helena / type Dist.' [Distant's handwriting], 'Distant Coll. / 1911-383.' [printed]. No type was designated in the original description so the labelling of the specimen as type does not constitute a valid type designation. Since no other material clearly belonging to the type series is available, this specimen is herewith designated as the lectotype and labelled accordingly.

As in the previous species, the type material of $C$. fratercula at the BMNH consists of a single male. This specimen is labelled as follows: two labels 'Type' [printed in round label with red margin], 'Tonquin' [handwritten], 'Cosmopsaltria / fratercula / type Dist.' [Distant's handwriting]. Again no type was designated in the original description, so the labelling of the specimen as type does not constitute a valid type designation. No other material clearly belonging to the type series is available, so this specimen is herewith designated as the lectotype and labelled accordingly.

Examination of the lectotypes of $D$. nagarasingna and $D$. helena has shown that they are almost identical, the only difference being that the latter specimen is less patterned on head and thorax. The structure of the genitalia is identical. $D$. nagarasingna and $D$. helena are thus considered to be synonymous. 
The resemblance between the lectotypes of $D$. nagarasingna and $D$. fratercula is much less straightforward. Both the shape of the apices of the uncus lobes and the shape of the opercula are different. After examining more material it became clear that the characters in each of the specimens represent extremes in a range of shapes. In neither case it is possible to distinguish discrete groups and the variation in both characters does not seem to be correlated, although there seems to be a geographical component. The variation is further described and discussed below. Since no other characters seem to justify a separation of $D$. fratercula from $D$. nagarasingna, $D$. fratercula is herewith synonymized with $D$. nagarasingna.

Material examined. - Vietnam: Bac Ninh, Tonkin, 1898, Noualhier, $1 \sigma^{\circ}$, MNP; Baria [Ba Ria], Cochin Chine, 1911, Vauthier, 2 o $\sigma^{\circ}$, MNP; Chapa [Cha Pai], Tonkin, v-vi.1916, R.V. de Salvaza, $1 \sigma^{\circ}$, BMNH; Cochin [Cochin Chine], $1 \sigma$, BMNH; Cochin Chine, 1878, Pierre, 1469 78, 4 o' $\sigma^{\circ}$, MNP; Région de Hoa Binh, Tonkin, 1936, A. de Cooman, $3 \sigma^{\circ} \sigma^{\circ}, 2$ ९, MNP; Tonquin [Tonkin], lectotype ơ Cosmopsaltria fratercula, BMNH; Tuông Döc [Thuong Duc] ... [bis?] Binh Dinh [An Nhon], Annam, 1900, T. Hamon, 1 ơ, BMNH.

Cambodia: Kiri Rom, 700 m, 31.iii-7.iv.1961, N.R. Spencer, $1 \circ$, BPBM.

Laos: Ban Nahan, J.F. Godfrey, 1 o, 1 \%, BMNH; Ban Saloueun, Luang Prabang, 9.iii.1920, R.V. de Salvaza, 1 ơ, BMNH; Laos inférieur, 1876, J. Harmand, 1093 76, 3 o $\sigma^{\prime}, 1$ , MNP; Mouc Dahan, J.F. Godfrey, $1 \sigma^{\circ}$, BMNH; Vientiane, Vientiane Prov., 22.iii.1966, J. \& J.H. Sedlacek, $1 \sigma^{\circ}$, BPBM.

Thailand: Bangkok, Bang Khen, 17.ii.1988, W.H., 1 ơ, BMNH; Chiengmai [Chiang Mai], 1100-1500 m, 1966, J. Sedlacek, 1 \% , BPBM; Chiangrai [Chiang Rai], iv.1951, D. \&

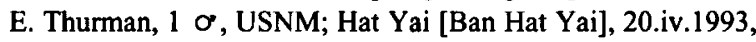
M. Gogola, 1 o , ZMA; Mae Hong Son, 31.iii.1993, M. Gogola, 1 ơ, ZMA; Nonthaburi, 16.ii.1988, W.H., 1 o , BMNH; same data, 1 ơ, ZMA; Patong Beach, Phuket, 5-9.iii.1986, T. \& M. Simon Thomas, 1 o , 1 \& , ZMA; Prov. Pachim [Prachin Buri], J.M. Bel, $1 \sigma^{\circ}$, BMNH; Sakaerat [Ban Huai Sakae Rat], Khorat Prov., 300-400 m, 1-2.iii.1968, D.E. Hardy, 1 o, 1 \&, BPBM; Siam, H.R.H. Prince of Chumpon, $1 \propto \circ, \mathrm{BMNH}$.

Burma: Burma, Bingham, 1 o, BMNH; Myitta, Tenass. Vall. [Tenasserim Valley], Doherty, 4 o $\sigma$, BMNH; N.W. Burmah [Burma], $\sigma^{*}$ lectotype and $1 \sigma^{*}$ paralectotype Dundubia nagarasingna, BMNH; Rangoon, Archbold, $40^{\circ} 0^{\circ}, 1$ ㅇ, BMNH.

India: Dehra Dun, o lectotype Dundubia helena, BMNH.

Locality unknown: label illegible, $1 \sigma^{\circ}, \mathrm{BMNH}$.

Females probably belonging to this species. - Vietnam: Hoa Binh, Tonkin, 1919, J. De Cooman \& R. Oberthur, 4 \& \&, MNP; Lao Kay [Lao Cai], Indo-China, R. Vitalis, 1 \&, BMNH; rég. de Hoa-Binh, Tonkin, A. De Cooman, 1926, 1 \&, MNP; rég. de Hoa-Binh, Annam, R.P.M. Maunier, 1903, 1 \&, MNP; Tonkin, vi.1917, V. de Salvaza, 1 \&, BMNH.

Laos: Ban Van Eue, 13-15.iv.1965, J.L. Gressitt, 1 \&, BPBM; Ban Van Eue, Vientiane Prov., 800 m, 11.iv.1965, J.L.
Gressitt, 1 \&, BPBM; Piahat, vi.1917, R.V. de Salvaza, 1 १, BMNH.

Thailand: Kanchanaburi Dist., 26.iii.1986, M.G. Allen, 1 우, BMNH; Naklud, prov. Chonburi, ca. $150 \mathrm{~km}$ Z.O. van [southeast of] Bangkok, A.C.J. Bongers, 1 \&, RMNH; Siam, Bocourt, 327 62, 1 \%, MNP; Siam, Prince of Chumpon, 1 \&, BMNH.

Burma: Burma, A.C. Mole, 1 \&, BMNH.

Locality unknown: ' 25 ', 1 \&, BMNH.

Remarks. $-D$. nagarasingna is a rather large-sized species but generally somewhat smaller than $D$. feae and D. hainanensis. The colour ranges from ochraceous brown to castaneous. This species is highly variable in the shape of the operculum (Figs. 28-32). The shape of the apices of the uncus lobes shows a geographical cline (Figs. 21-27) but is distinctly different from that of $D$. hainanensis.

The record by Ishihara (1961) is provisionally listed here. The specimen illustrated (Ishihara, 1961: pl. 1 fig. 1) could not be examined but resembles $D$. nagarasingna rather than $D$. hainanensis.

Variation. - This species is highly variable in a number of characters, each of them with the potential of creating confusion about identification. The shape of the medial projection of the uncus lobes (Figs. 21-27) shows a geographical cline. In specimens from the western part of the range the medial projection is narrower and two-tipped with two close-set, small apical spines (Figs. 21-23), whereas in the specimens from the eastern part the medial projection is broader and bifurcate, each of the tips sharply pointed and often curved (Figs. 2627). The broadening of the projection is accompanied with the shift of the position of the outer spine towards the ventral part of the uncus and with an increase in the size of the spines to create the bifurcate character of the projection. It should be noted, however, that specimens apparently from the same series do also display variation.

The shape of the male operculum shows considerable variation (Figs. 28-32) that is independent of the variation in the shape of the medial projection of the uncus lobes. The shape of the operculum ranges from rather short and smoothly rounded at the apex (Fig. 29) to rather long and apex attenuated or sometimes gully-shaped at the tip (Figs. 31-32). 

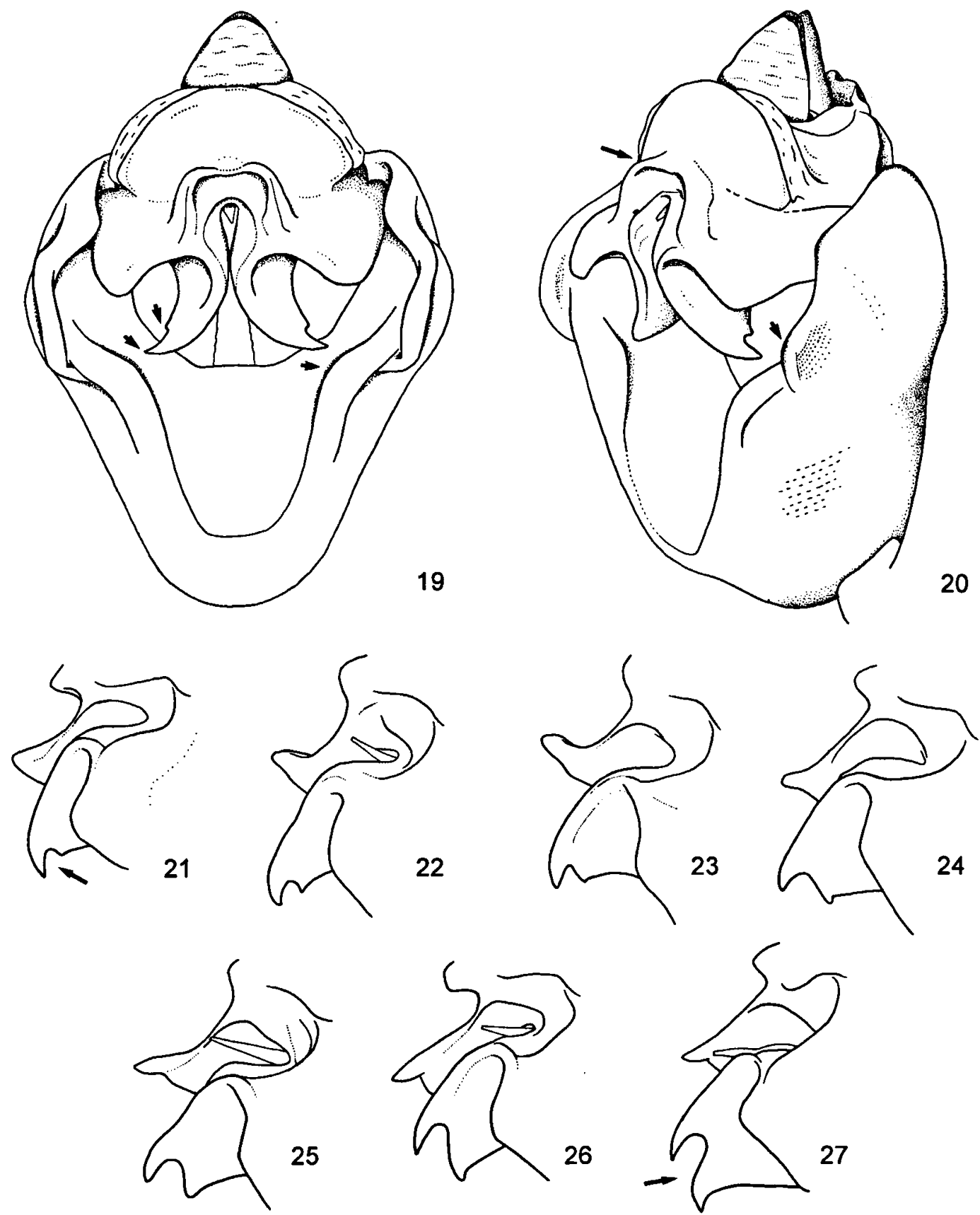

Figs. 19-27. Dundubia nagarasingna Distant, 1881, male: 19, pygofer and uncus in ventral view, lectotype $D$. nagarasingna; 20, pygofer and uncus in lateroventral view, lectotype $D$. nagarasingna; 21 , distal part of uncus in lateroventral view, lectotype $D$. nagarasingna; 22, id., Ta Mode; 23, id., Vientiane; 24, id., Chiang Mai; 25, id., Laos inférieur; 26, id., Kiri Rom; 27, id., Tonkin, lectotype $D$. fratercula.

Description. - Body light to dark castaneous brown with a lighter pattern on head and pronotum, darkest parts usually on head and pronotum, ventral parts paler than dorsal parts.
-Head: Postclypeus castaneous but ventrally lighter, anteromedial spot ochraceous brown and area anterior of frontoclypeal suture often lighter castaneous or ochraceous brown. Anteclypeus 


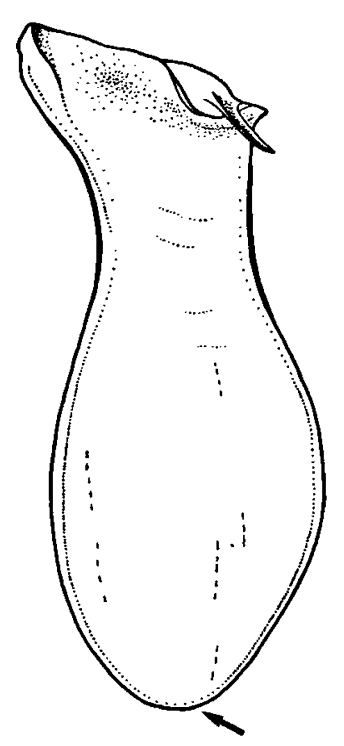

28
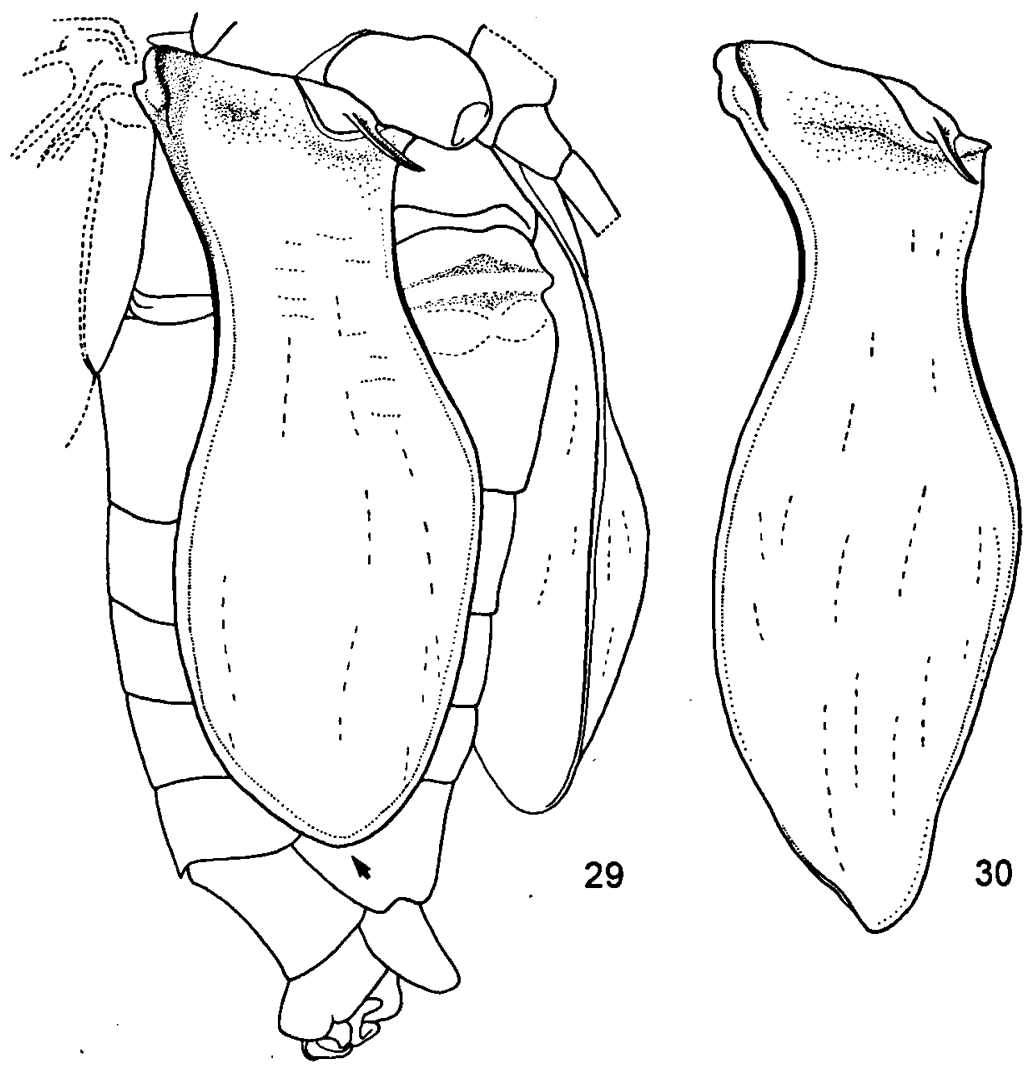

Figs. 28-30. Dundubia nagarasingna Distant, 1881, male: 28, right operculum in lateroventral view, Mae Hong Son; 29, id., lectotype D. nagarasingna; 30, id., Laos inférieur.

concolorous with ventral part of postclypeus. Vertex castaneous with supra-antennal plates and narrow stripes running from these lobes to posterior margin of vertex brownish to ochraceous brown. Suture between vertex lobes and supra-antennal plates distinct and merged with a longitudinal groove running along lateral part of frontoclypeal suture and between eye and lateral ocellus. Frontoclypeal suture trapezoid, medial part wider than distance between lateral margins of lateral ocelli, sometimes suture almost semicircular. Rostrum brownish, blackened at apex, usually reaching at least middle of hind coxae, only rarely beyond.

Thorax: Pronotum slightly broader than head, although in males occasionally just narrower than head. Pronotal disc castaneous, anterior margin and median fascia ochraceous brown or sometimes more olivaceous; medial spot in front of pronotal collar either present or absent. Pronotal collar ochraceous brown to olivaceous with black posterior margin and often with brown spots anteriorly and medially on lateral part and spots posterior of lateral lobe of pronotal disc, latter spots sometimes extending medially and in rare cases forming a transverse band; anterior corner with short blunt to pointed lateral tooth, posterior corner smoothly rounded. Mesonotum ochraceous brown to castaneous with paler fasciae lateral of mesonotal fissures, sometimes with paler obconical spots between mesonotal fissures or with medial area paler; cruciform elevation often paler than disc except for medial area. Katepimeral lobe (Fig. 36) narrowing towards apex and longer than basal width; dorsal margin almost straight or somewhat concave on basal half, then convex to apex; apex narrowly rounded but sometimes slightly angular; ventral margin concave, lobe narrowing close to base. Surface of katepimeral lobe slightly concave 


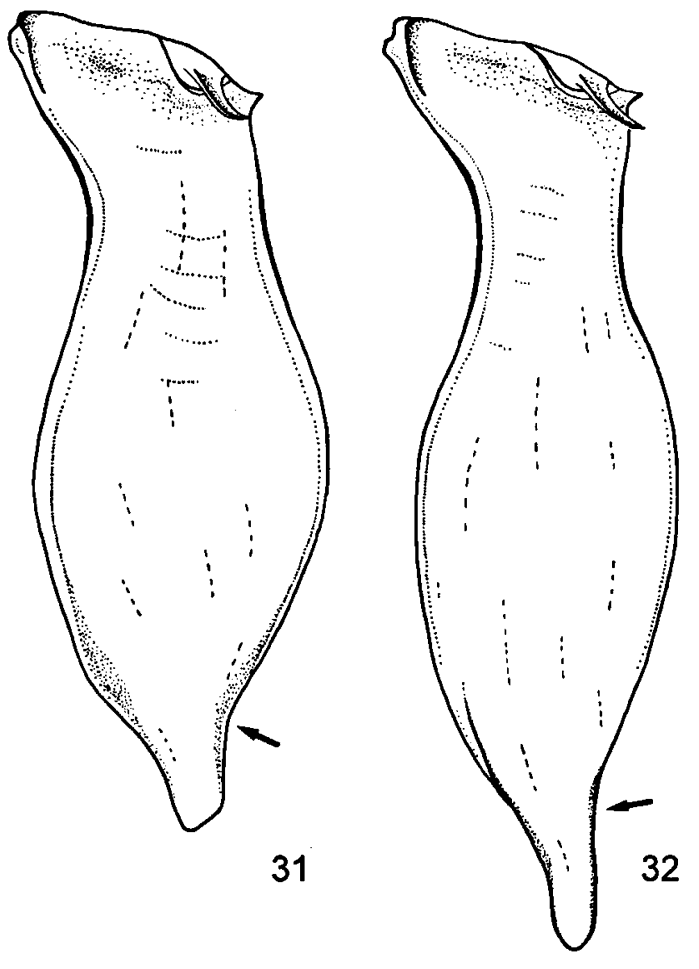

Figs. 31-32. Dundubia nagarasingna Distant, 1881, male: 31, right operculum in lateroventral view, Vientiane; 32, id., Mouc Dahan.

on dorsal half, densely covered with short hairs and waxy coating and with some scattered long hairs; hairs on margins somewhat longer, especially on ventral margin. Apex of katepimeral lobe just reaching base of operculum or shorter.

Tegmina and wings: Tegmina hyaline; basal cell hyaline or with pale infuscation. Veins of tegmen ochraceous to brownish but costa, cubital vein and first anal vein darker, basal part of medial vein also darker except at extreme base. Wings hyaline; veins ochraceous to brownish.

Legs: Ochraceous to brownish and often partially darkened but most of darkening without distinct pattern. Fore femora always with dark posteroventral stripe, posterodorsal stripe and anterior spot near apex either present or absent; fore tibiae darkened ventrally, when extensively darkened then darkening extending to dorsal part near apex; fore tarsi brownish. Mid femora either with or without anterodorsal stripe, sometimes only brown spot near apex; mid tibiae darkened dorsally and ventrally, when extensively darkened then stripes joining near apex; mid tarsi dark brown. Hind femora either with narrow anterodorsal and posterodorsal stripes that are joined in darker specimens or without stripes; hind tibiae darkened ventrally on distal half; hind tarsi darkened apically. Fore femur with proximal spine long and rather blunt, middle spine shorter and pointed, distal spine small and blunt, gap between middle and distal spines broad and not very deep. In rare cases hind tibia lacking proximal dorsal spine or with fourth anteroventral spine at about $40 \%$ from base.

Male. Operculum (Figs. 28-32): Very variable in length and shape. Long, reaching from just beyond anterior margin of fifth abdominal segment to posterior margin of eighth abdominal segment, 2.53.5 times as long as maximum width distal of constriction; ochraceous but sometimes with greenish tinge, lateroproximal corner and lateral margin halfway into concavity dark brown. Medial margin concave near base, distal of constriction first convex, variable near apex. Apex variable in shape; apex rounded when both medial and lateral margins are convex near apex (Figs. 28-29); apex angular when either margin or both margins are almost straight or either of them is slightly convex near apex (Fig. 30); apex produced when either margin more strongly concave or both slightly concave near apex (Figs. 31-32); tip can be on either side of longitudinal midline of operculum. Lateral margin concave at level of timbal covering and somewhat beyond, distal of constriction first convex, variable near apex. Constriction at 0.2-0.4 of length of operculum, medial concavity less deep than lateral concavity, broadest part of operculum distal of constriction 1.4-1.8 times as wide as minimum width in constriction. Distance between opercula at constrictions 1.5-1.9 times as wide as minimum width in constriction. Opercula at point of closest approximation separated for a distance of 0.6-0.9 times maximum width between opercula constrictions. Surface of operculum distal of constriction strongly convex, curved around abdomen at lateral margin, surface less convex when apex is more angular, or surface gouge-shaped at apex when apex is produced. 


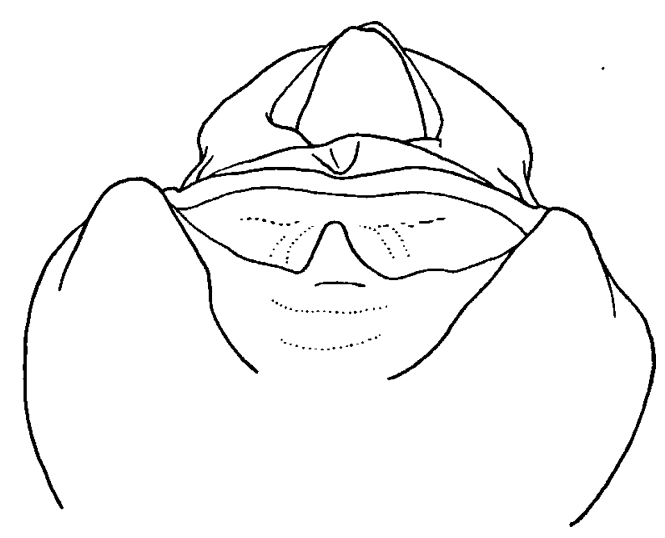

33

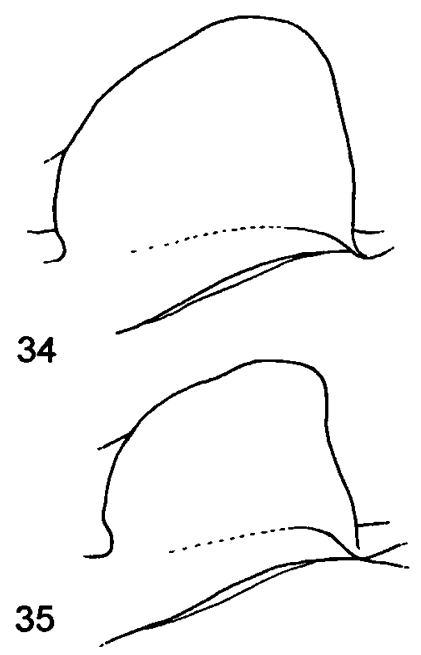

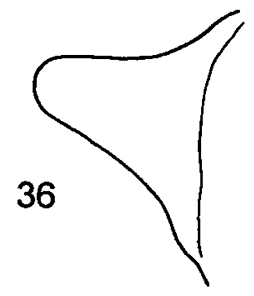

Figs. 33-36. Dundubia nagarasingna Distant, 1881, male: 33, pygofer in dorsal view, Mae Hong Son; 34, right timbal covering, lectotype $D$. nagarasingna; 35 , id., Mae Hong Son; 36, right katepimeral lobe, lectotype $D$. nagarasingna.

Abdomen: Length 1.1-1.3 times that of head and thorax together. Ochraceous brown to castaneous but posterior tergites somewhat darker, lateral parts often somewhat paler than medial part, sternites and ventral parts of tergites ochraceous to ochraceous brown. Tergites 3-6 usually with indistinct brown lateral spots. Dorsal part of abdomen with pattern consisting of three longitudinal bands of greyish pilosity, one broad band medially and two narrow bands posterior of timbal coverings; pilosity often partially or completely rubbed off. Posterior margins of tergites 6 and 7 with short dark spinules. Timbal covering (Figs. 34-35) brownish but often darker on medial, lateral, and distal margins, about 1.1-1.2 times as wide as long; medial margin very short; mediodistal corner broadly rounded; distal margin oblique and convex; laterodistal corner rounded, lateral margin almost straight. Sternite 7 with shallow, rounded posteromedial emargination.

Genitalia (Figs. 19-27, 33): Ochraceous brown, dorsal part of pygofer and apices of uncus lobes often more brownish or castaneous. Basal pygofer lobes formed by swollen continuation of anteroventral margin, smoothly rounded (Fig. 19); hairs on anteroventral margin and basal lobes long, those on basal lobes even slightly longer than those on margin, a few scattered hairs on pygofer surface anterior of anteroventral margin. Basal part of uncus little globose, broad and rather triangular, angles rounded (Fig. 19), near bases of uncus lobes with some short, pale, thick hairs. Uncus lobes very short and raised compared to basal part of uncus (Fig. 20), connected by semicircular rim around aedeagal opening, rim continuing to distal margin (Figs. 19-20); medial margin and mediodistal corner strongly curved inwards and produced into medial two-tipped to bifurcate projection, ranging in shape from two close-set small spines (Figs. 21-23) to two more widely separated, sharply pointed and curved thorn-like spines (Figs. 26-27); distal margin concave or almost straight; laterodistal corner broadly rounded; lateral margin weakly convex; uncus lobes with many erect hairs, those on flat surfaces long, those near margins shorter.

Female. Operculum brownish, darkened in lateroproximal corner but occasionally along whole proximal margin just reaching beyond base of sternite 3 , only little curved around abdomen laterally. Lateral margin distal of lateroproximal lobe weakly convex to weakly concave; laterodistal corner angularly rounded or sometimes even angular; distal margin weakly convex to almost straight; mediodistal corner broadly rounded; medial margin short and convex; lateral and medial margin of each operculum convergent from base. 
Abdomen: Length 0.9-1.0 times that of head and thorax together or little longer. Dorsal part of tergites dark brown to castaneous, sometimes little paler on anterior segments; sternites and ventral parts of tergites ochraceous to ochraceous brown. Tergites 3-5 near lateral margin with darker spots that may be very indistinct or completely covered by dense cover of short silvery hairs. Posterior margin of tergite 3 rarely with a few short dark spines laterally, posterior margin of tergites 4-7 with more numerous and longer spines but spines fewer in number and shorter on tergite 4; posterior margin of tergite 8 with scattered longer spines medially. Tergite 8 usually heavily grey tomentose. Sternite 7 with a rounded to angular posteromedial emargination.

Genitalia: Dorsal part of pygofer brownish, especially darker on caudodorsal beak, lateroventrally often with narrow longitudinal brown stripes, remainder ochraceous to ochraceous brown; distal part of ovipositor sheath almost castaneous. Dorsal margin of pygofer in lateral view slightly concave, ventral margin slightly convex. Ovipositor sheath reaching as far as or beyond apex of caudodorsal beak; anal valve not reaching as far as caudodorsal beak.

Measurements in $\mathrm{mm}\left(\sigma^{*}: \mathrm{n}=9\right)$. - Body length: $\sigma^{\prime}: 33.5-39.0$ $(36.3 \pm 1.1), \wp: 34.5-37.0(35.4 \pm 0.9)(n=4)$; head width: $\sigma:$ 10.7-12.0 (11.4 \pm 0.3$)$, $: 12.1-12.8(12.4 \pm 0.3)(n=4)$; maximum pronotum width: $\sigma^{\prime \prime}: 10.9-13.1(11.5 \pm 0.3)$, $९: 12.4-12.9$ $(12.7 \pm 0.2)(n=3)$; tegmen length: $\sigma^{\prime}: 39.0-43.0(40.9 \pm 1.3)$, ९: 43.5-46.5 $(44.7 \pm 1.2)(n=3)$.

Distribution (Fig. 2). - D. nagarasingna is the most widely distributed species of the $D$. jacoona assemblage and found throughout most of IndoChina (excluding the most northern parts) and on the Malay Peninsula (but not in Peninsular Malaysia). Records from China (Kato, 1934*) and from Japan (Metcalf, 1963b) could not be confirmed. The record from Japan by Metcalf was ascribed to Kato $\left(1941^{*}\right)$ but this may be based on a misinterpretation or on a wrong translation of Kato's paper.

It should be noted that the type locality of $D$. helena (Dehra Dun, India) is well outside the main range of $D$. nagarasingna. The localities closest to this locality lie in Burma, more than $2,000 \mathrm{~km}$ to the east. This casts doubt on the correctness of the data on the label.

Biological notes. - The specimens from Ban Huai Sakae Rat, Thailand were collected in a dry diplocot forest. Gogala (1995) reported that $P$. nagarasingna was found gregarious in Hat Yai, Thailand.

Song. - Gogala (1995) discussed the songs of cicadas recorded in Thailand. The recorded species included $D$. nagarasingna in Hat Yai (as $P$. nagarasingna), and a species named Platylomia sp. from the Mae Hong Son region. The species were similar in morphology and chorusing behaviour. The song patterns of these species were similar though not identical in pattern and the latter species often sang in the middle of the day in contrast to the former. Voucher specimens for both species were examined and Platylomia sp. proved to belong to D. nagarasingna.

Variations in morphology, song pattern, and timing of singing is not often recorded because hardly any extensive research has been done. Hayashi (1975) gives an account of variation in all three features in some species of Meimuna occurring in the Ryukyu Archipelago.

\section{Dundubia myitkyinensis $\mathrm{n}$. $\mathrm{sp}$.}

(Figs. 2, 37-44)

Material examined. - Holotype o": 'Myitkyina Burma / v.20. 1945 / Grant W. Miller (SEM). Paratype: Burma: Myitkyina 12.v.1945, L. C. Kuitert, 1 \% (SEM).

Remarks. - D. myitkyinensis is castaneous brown and compared to $D$. nagarasingna this species is somewhat larger. The opercula are long and gradually narrowed towards the apex (Fig. 41), and the medial projections of the uncus lobes are covered by the ventral (outer) surface of the uncus lobes (Fig. 37).

Description. - Body castaneous brown with a lighter pattern on head and pronotum, darkest parts on head and pronotum, ventral parts paler than dorsal parts. 


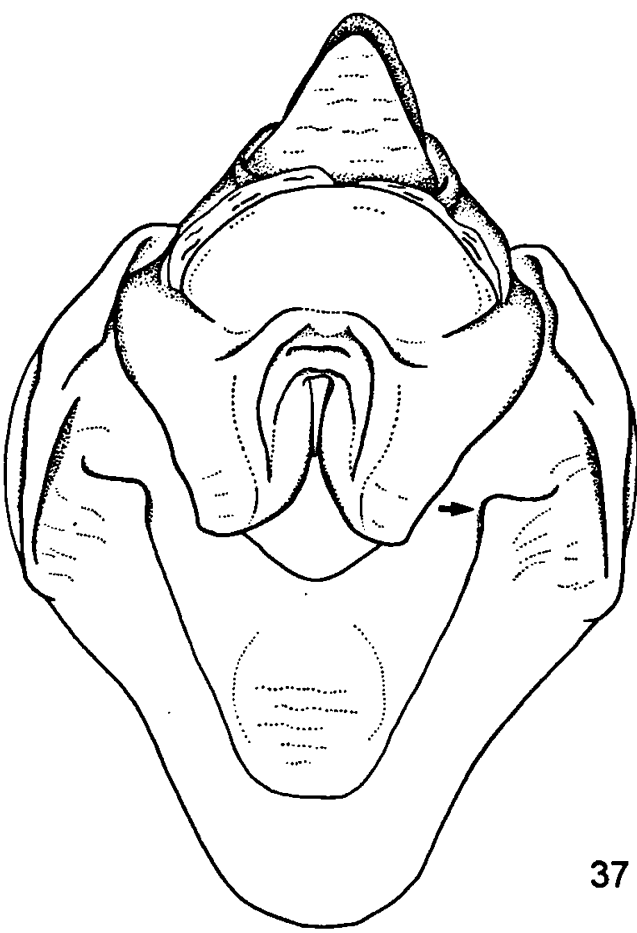

37

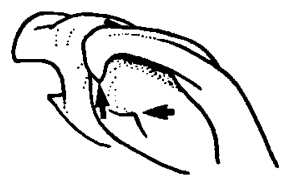

39

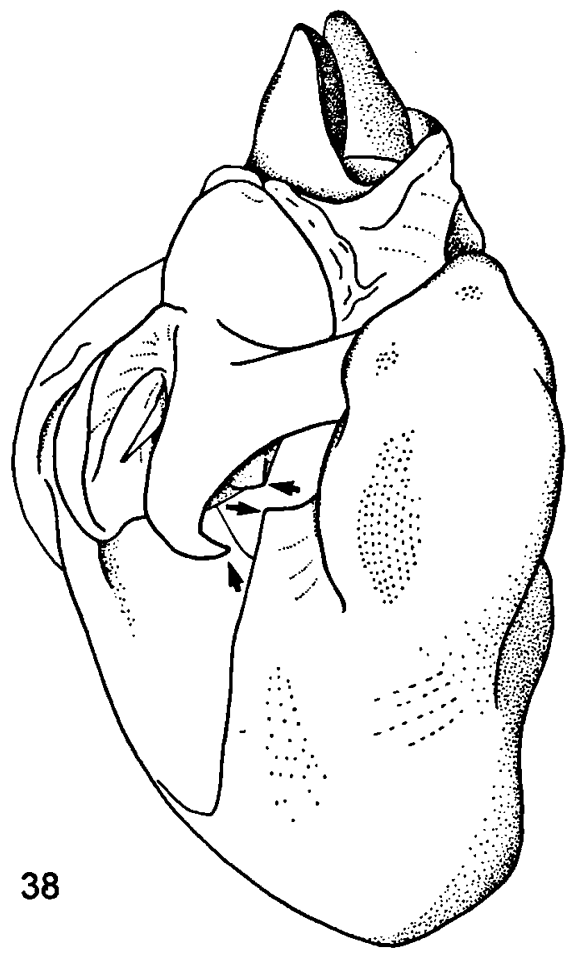

40

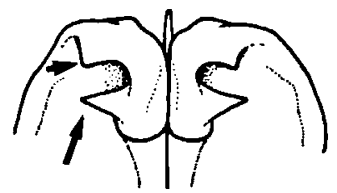

Figs. 37-40. Dundubia myitkyinensis n. sp., male, holotype: 37 , pygofer and uncus in ventral view; 38, pygofer and uncus in lateroventral view; 39, distal part of uncus in anterolateral view; 40. id., in dorsal view (inner part).

Head: Postclypeus castaneous but dorsal part slightly lighter, anteromedial spot and small areas lateral of medial line on ventral part ochraceous brown. Anteclypeus castaneous, part along clypeal suture and median line pale brownish. Vertex castaneous. Suture between vertex lobe and supraantennal plate as in $D$. feae. Frontoclypeal suture trapezoid, medial part wider than distance between lateral margins of lateral ocelli. Rostrum brownish, blackened at apex, almost reaching as far as posterior margin of hind coxae.

Thorax: Pronotum narrower than head. Pronotal disc castaneous, surface of paramedian and lateral lobes as well as narrow band just posterior of anterior margin darkest, anterior margin ochraceous brown but medially darker, median fascia ochraceous brown. Pronotal collar ochraceous brown with black posterior margin, anterolateral part brownish with indistinct darker brown spot, lateral part medially with distinct brown spot and spots posterior of lateral lobe of pronotal disc extending medially and forming transverse band; anterior corner with short somewhat blunt lateral tooth, posterior corner smoothly rounded. Mesonotum castaneous with paler fasciae lateral of mesonotal fissures, these fasciae broadening towards anterior margin and enclosing small triangular castaneous spots at anterior margin of disc; cruciform elevation paler than disc except for medial area and apical half of anterior arms. Katepimeral lobe (Fig. 44) narrow- 
ing towards apex and just longer than basal width; dorsal margin concave on basal half, then convex to apex; apex rounded; ventral margin straight on basal half, then concave. Surface of katepimeral lobe slightly concave, densely covered with short hairs and some waxy coating, hairs on margins only little longer; few scattered long hairs on ventral margin. Apex of katepimeral lobe just reaching over base of operculum.

Tegmina and wings: Tegmina hyaline; basal cell with yellowish infuscation. Veins of tegmen brownish, medial vein more ochraceous, second anal vein blackish. Wings hyaline; veins brownish, medial vein, second cubital vein, and first anal vein more ochraceous.

Legs: Brownish with pattern of darkening and some paler patches. Fore femora brownish with dark posteroventral stripe, anterior and posterior surface and narrow apical band more ochraceous; fore tibiae dark brown but ochraceous dorsally on basal third; fore tarsi dark brownish. Mid femora brownish with darkened anterior and posterior stripes that are separated dorsally by narrow brownish stripe; mid tibiae brownish with dark brown basal band and with dark brown stripes along whole length dorsally and ventrally; mid tarsi dark brown with anterior surface somewhat paler. Hind femora with narrow anterodorsal and posterodorsal stripes; hind tibiae as mid tibiae but dorsal stripe narrowly interrupted just distal of basal band; tibiae broken off halfway so hind tarsi missing. Fore femur with proximal and middle spines equally long; proximal spine rather blunt; middle spine pointed; distal spine small but distinct, pointed; gap between middle and distal spines rather narrow and deep.

Male. Operculum (Fig. 41): Long, reaching from just beyond posterior margin of eighth abdominal segment, about 3.6 times as long as maximum width distal of constriction; brownish, lateroproximal corner and lateral margin to about halfway into concavity dark brown. Medial margin concave near base, distal of constriction only weakly convex, especially about halfway operculum. Apex angular, almost pointed; tip situated lateral of longitudinal midline of operculum. Lateral margin concave at level of timbal covering and well beyond, distal of constriction weakly convex. Constriction at $0.2-0.3$ of length of operculum, medial concavity shorter and deeper than lateral concavity, broadest part of operculum distal of constriction about 1.9 times as wide as minimum width in constriction. Distance between opercula at constrictions about 1.8 times as wide as minimum width in constriction. Opercula at point of closest approximation separated for a distance of about 0.5 times maximum width between opercula constrictions. Surface of operculum distal of constriction convex but almost flat at distal fifth, hardly curved around abdomen at lateral margin.

Abdomen: Almost 1.2 times as long as head and thorax together. Tergites castaneous medially, more brownish laterally; sternites and ventral parts of tergites brownish but posterior sternites somewhat darker. Tergites 3-7 with dark brown lateral spots, those on tergites 6 and 7 rather small. Tergite 4 with very few scattered spine-like setae near posterolateral corner. Posterior margins of tergite 5 laterally with short dark spines except medially, posterior margin of tergites 6 and 7 with spines along whole length. Timbal covering (Fig. 43) brownish and broad, about 1.3 times as wide as long; medial margin very short; mediodistal corner broadly rounded; distal margin oblique and convex; laterodistal corner rounded, lateral margin almost straight. Sternite 7 with deep and rounded posteromedial emargination.

Genitalia (Figs. 37-40, 42): Ochraceous brown to brown, ventral part of pygofer and apices of uncus lobes palest. Basal pygofer lobes as in $D$. feae but more distinctly separated from lateral margin of pygofer (Fig. 37); hairs on pygofer as in $D$. feae, but virtually whole surface enclosed by anteroventral margin with hairs and with several long hairs at posterolateral margin. Basal part of uncus globose, broad and almost semicircular (Fig. 37), near bases of uncus lobes with several thick erect hairs. Uncus lobes short and raised compared to basal part of uncus (Figs. 37-38), connected by rim around aedeagal opening, rim almost continuing to distal margin (Figs. 37-38); medial and distal margin strongly curved inwards; medial margin with a sideways directed, pointed projection (Figs. 39-40); laterodistal corner produced 


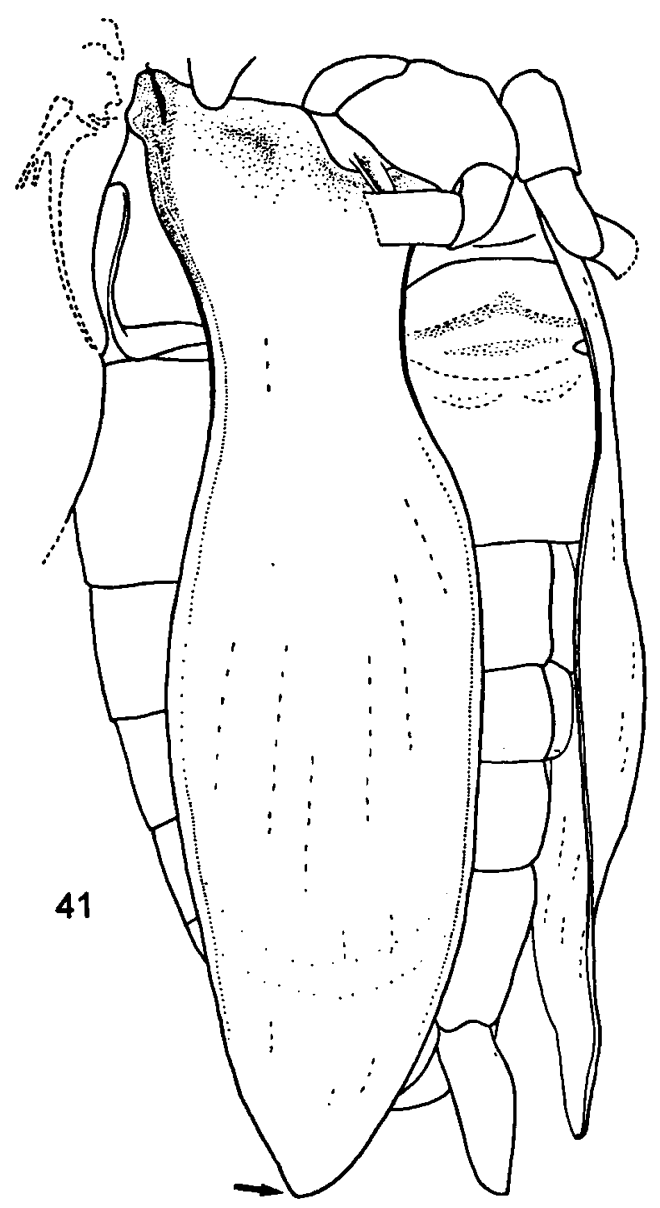

into backwards directed, pointed projection (Figs. 38-40); lateral margin weakly concave; uncus lobes with few erect hairs on outer (ventral) surface lateral of rim and with numerous setae on inner (dorsal) surface near bases of uncus lobes, hairs otherwise short.

Female. Operculum brownish, darker basally, just reaching beyond base of sternite 3 , only little curved around abdomen laterally. Lateral margin distal of lateroproximal lobe almost straight; laterodistal corner angularly rounded; distal margin weakly convex; mediodistal corner broadly rounded; medial margin short and convex; lateral and medial margins of each operculum convergent from base.

Abdomen: About as long as head and thorax together. Dorsal part of tergites castaneous, little paler on anterior segments; sternites and ventral parts of tergites brownish. Tergites 2-7 densely

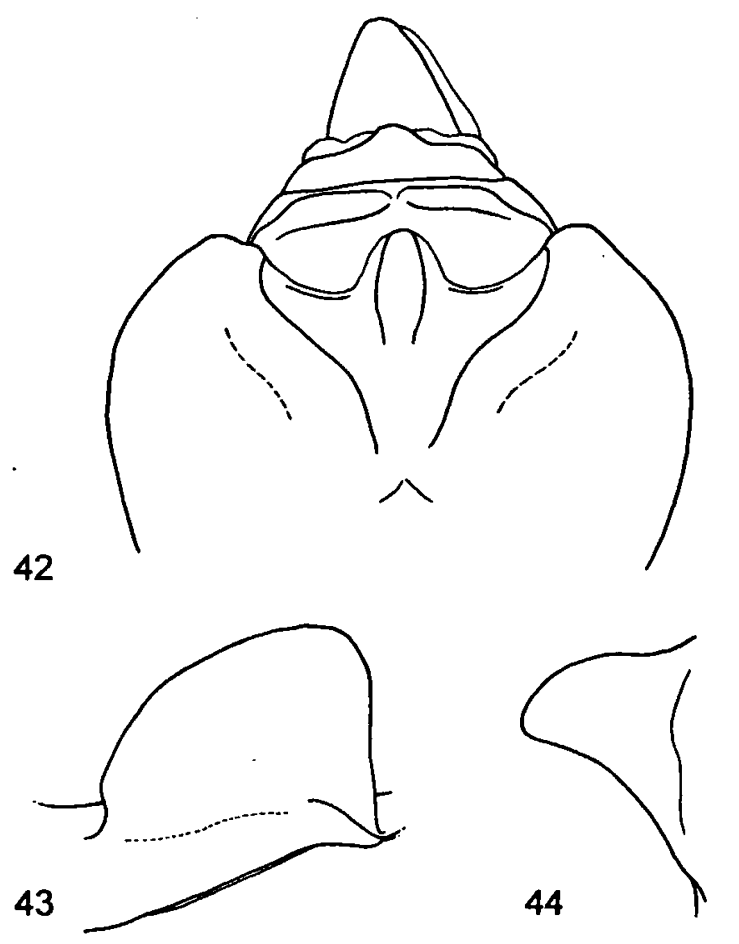

Figs. 41-44. Dundubia myitkyinensis n. sp., male, holotype: 41, right operculum in lateroventral view; 42, pygofer in dorsal view; 43, right timbal covering; 44 , right katepimeral lobe.

covered with short silvery hairs, hairs hiding darker spots near lateral margin whenever these spots are present. Posterior margin of tergites 4-7 with numerous and long spines, those on tergite 4 shorter, more slender and fewer in number; posterior margin of tergite 8 with scattered spines except laterally. Tergite 8 heavily grey tomentose. Sternite 7 with an almost indistinguishable posteromedial emárgination.

Genitalia: Dorsal part of pygofer and distal part of ovipositor sheath dark brown, remainder brownish. Dorsal margin of pygofer in lateral view slightly concave, ventral margin slightly convex. Ovipositor sheath hardly reaching beyond apex of caudodorsal beak; anal valve not reaching as far as caudodorsal beak.

Measurements in $\mathrm{mm}\left(\sigma^{\circ}: \mathrm{n}=1, Q: \mathrm{n}=1\right)$. - Body length: $\sigma^{*}$ : 41.5, $\odot: 38.0$; head width: $\sigma: 13.8$, $\odot: 13.3$; maximum pronotum width: $\sigma^{\prime}: 13.3$, $\odot: 13.9$; tegmen length: $\sigma^{\circ}: 46.5, \wp: 47.0$. 
Distribution (Fig. 2). - This species is only known from the type locality in northern Burma.

Etymology. - This species is named after the type locality.

Dundubia nigripes (Moulton, 1923) n. comb. (Figs. 5, 45-50)

Dundubia mannifera (nec Walker) var. a; Distant, 1889: 39 (partim: Perak); 1892a: pl. XII figs. 1-1b; 1892b: xi (partim: Malay Peninsula).

Dundubia mannifera; Distant, 1906a: 94 (partim: Malay Peninsula).

Cosmopsaltria nigripes Moulton, 1923: 89, figs. 6-6b.

Orientopsaltria nigripes; Duffels, 1983: 9.

Dundubia rafflesii; Overmeer \& Duffels, 1967: 51 (partim: Malaya).

Not: Dundubia mannifera (nec Walker) var. a; Distant, 1889: 39 (partim: North Khasi Hills); 1892b: xi (partim: India) (see $D$. laterocurvata).

Lectotype designation. - Moulton (1923) described this species from the Malaysian states Negeri Sembilan, Selangor, Perak, and Kedah, and stated that the type is at the BMNH but did not specify any further details concerning the (holo)type. So even though a specimen deposited at the BMNH does bear a label indicating that it is a type, this cannot be considered a valid type designation. This specimen bears the following labels: 'Type' [printed in red circle]; "TYPE $\sigma$ / Cosmopsaltria / nigripes Moulton / 13.vi.22' [Moulton's handwriting]; '24' and 'Selangor / F.M.S.' on the reverse side; 'Pres. Raffles Mus. / Singapore. / Brit. Mus. / 1922-302' [printed]. It is herewith designated as lectotype.

The material Distant (1889) recorded as Dundubia vaginata var. $a$ from Perak and North Khasi Hills is indeed different from other specimens of Dundubia vaginata. It seems unlikely, however, that specimens from these localities represent the same species. The material from the former locality represents $D$. nigripes (see Moulton, 1923: 90) and that from the latter most likely represents $D$. laterocurvata.

Material examined. - Peninsular Malaysia: Bukit Kutu, 15.xii.1915, 2 o* o*, BMNH; Bukit Kutu, 3300 ft, 1920-1925, A.R. Sanderson, $1 \sigma^{\circ}, \mathrm{BMNH}$; Bukit Kutu, Selangor, $3500 \mathrm{ft}$, 21.iii.1931, at light, H.M. Pendlebury, $1 \sigma^{\circ}$, BMNH; Cameron Highlands, light trap, 18-19.iii.1966, J. \& M. Sedlacek, 1 o", BPBM; Fraser's Hill, Pahang, $4000 \mathrm{ft}$, 26.ii.1929, H.M. Pendlebury, $10^{\circ}$, BMNH; Fraser's Hill, Kuala Lumpur, Pahang, $3000 \mathrm{ft}$, i-iii.1951, I. Clausen, 1 ơ, UZMK; Fraser's Hill, Pahang, 4000 ft, 29.i.1929, H.M. Pendlebury, 1 o*, BMNH; same data, 31.i.1929, $1 \sigma^{\circ}$, BMNH; same data, 1.ii.1929, $1 \sigma^{\circ}$, BMNH; same data, 4200 ft, 2.i.1930, 1 o', ZMA; Fraser's Hill, 30.iii.1930, A.S. Corbet, $1 \sigma^{\circ}$, ZMA; The Gap, iii.1921, 3 o o o',
BMNH; Genting Highlands, Pahang, 22.ii.1994, Zaidi, Ruslan, Saiful, 1 O’, UKMS; Kuala Lumpur, 25.i.1931, at light, H.M. Pendlebury, $10^{\circ}$, BMNH; Larut Hills, Perak, $3750 \mathrm{ft}$, at light, 6.ii.1932, H.M. Pendlebury, 1 Oे $^{\circ}$ BMNH; same data, $4500 \mathrm{ft}$, 23.x.1932, 1 ơ , BMNH; Maxwell Hill, 1350 m, 17-20.iii.1958, T.C. Maa, 1 o*, BPBM; Malacca, ii. 1908, 1 o*, BMNH; Perak, $20^{\circ} \mathrm{O}^{\circ}, \mathrm{BMNH}$; Selangor, lectotype Cosmopsaltria nigripes $0^{\circ}$, BMNH; Tanjong Hantu, light-house, 1924, 1 o', BMNH.

Remarks. $-D$. nigripes is a medium-sized species with a colour pattern on head and thorax that may be indistinct. It is further characterized by the elongated and strongly narrowed uncus lobes (Figs. 45-46).

Description. - Body ochraceous brown to castaneous, when darker often with a lighter pattern on head and thorax, ventral parts paler than dorsal parts, mesonotum with distinct dark paramedian fasciae and sometimes indication of lateral fasciae; opercula slightly darkened near apex; legs with darkened parts.

Head: Postclypeus ochraceous brown to brown, lateral and ventral of anteromedial spot darker; ochraceous brown to brown colour of anteromedial spot may extend all the way to frontoclypeal suture. Anteclypeus brown, lighter on median line and along margins. Vertex brownish, darker on area around ocelli, on vertex lobes and lateral part of vertex and on anterior margins of supra-antennal plates. Genae ochraceous brown to brown with darker transverse band just below antennae between eyes and postclypeus. Suture between vertex lobe and supra-antennal plate with distinct pits near anterior margin of vertex lobes and also where suture meets longitudinal groove running along lateral part of frontoclypeal suture and between eye and lateral ocellus. Frontoclypeal suture almost trapezoid but with tendency to be somewhat semicircular; width of medial part compared to distance between lateral margins of lateral ocelli variable. Rostrum ochraceous brown to brown, blackened at apex, just reaching between hind coxae.

Thorax: Pronotum about as broad as head. Pronotal disc ochraceous brown to brown, central fasciae and posteromedial part of paramedian lobes usually distinctly darker brown; medial spot in front of pronotal collar distinct, dark brown to blackish and sometimes split into two smaller 

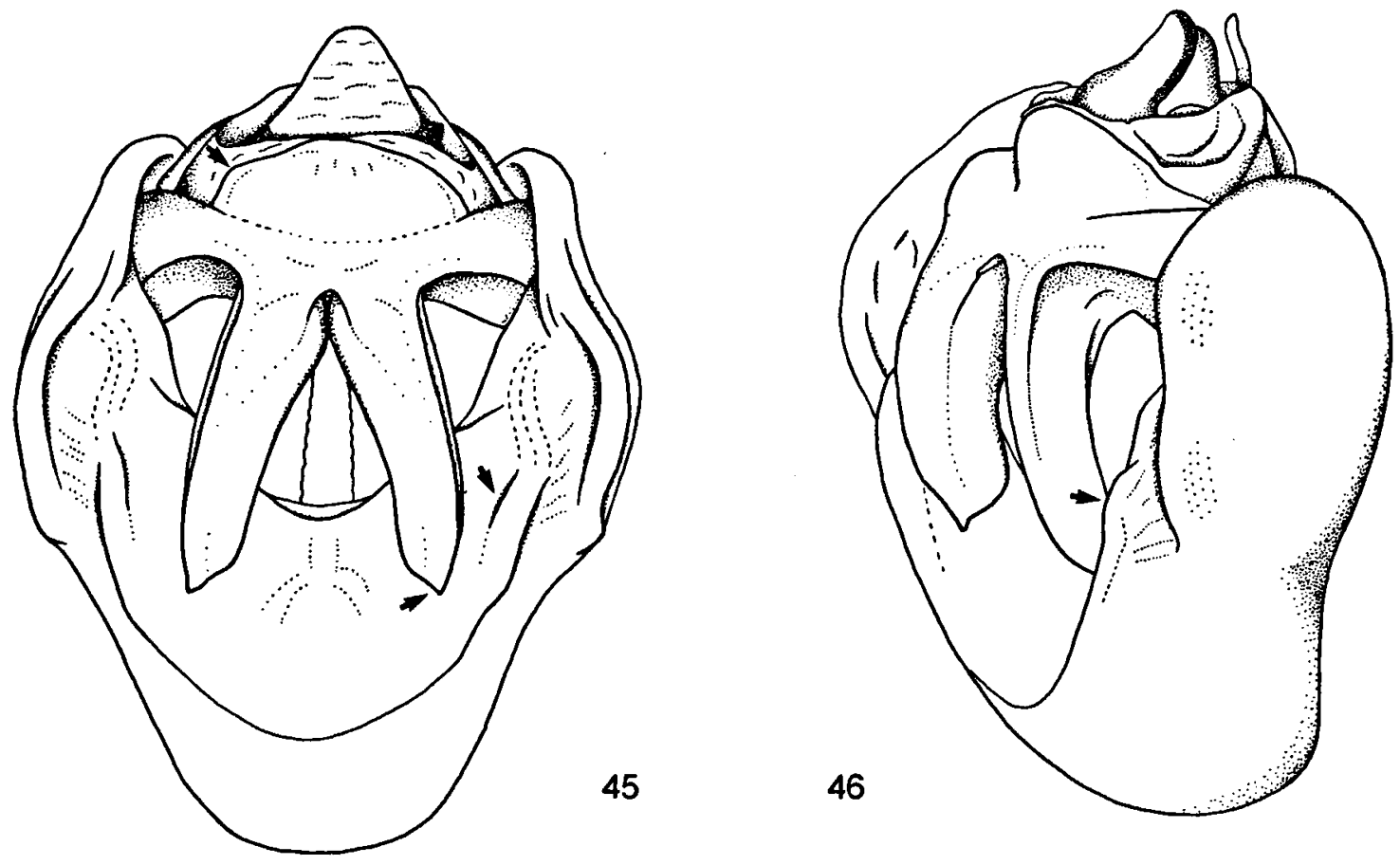

Figs. 45-46. Dundubia nigripes (Moulton, 1923), male, Genting Highlands: 45, pygofer and uncus in ventral view; 46, pygofer and uncus in lateroventral view.

spots and extending slightly on to pronotal collar. Pronotal collar ochraceous brown to olivaceous with black posterior margin; lateral part of collar with brown spot close to lateral margin and usually a second, smaller and less distinct spot medial of it; occasionally with brown spots at posterior margin of lateral lobes of disc; anterior corner with small pointed lateral tooth, posterior corner smoothly rounded. Mesonotum ochraceous brown to brown; median fascia absent or indistinct, if present then broadened towards and split anterior of cruciform elevation; paramedian fasciae narrow and dark brown to blackish, immediately medial of mesonotal fissures, posterior part of fasciae paler; fasciae curved towards each other or even towards anterior margin close to medial line, sometimes fused on medial line or joining median fascia; lateral fasciae sometimes present as elongated brown spots close to posterior margin of disc, rarely developed on anterior half of disc. Cruciform elevation somewhat paler than disc. Katepimeral lobe (Fig. 50) longer than basal width; dorsal margin almost straight, only weakly concave at base and weakly convex towards apex; apex rounded but almost angular; ventral margin concave close to base, straight or slightly convex towards apex. Surface of katepimeral lobe slightly concave, especially on dorsal half; covered with short hairs and sometimes with some waxy coating, hairs on ventral and apical margins somewhat longer. Apex of katepimeral lobe distinctly reaching over base of operculum but sometimes only little.

Tegmina and wings: Tegmina hyaline with indistinct brownish reticulation between veins in distal part; basal veins of second and third apical cells almost imperceptibly infuscate; basal cell with pale infuscation. Veins of tegmen brownish, costal vein and anal veins paler. Wings hyaline; veins brownish, paler in basal part of wing.

Legs: Fore legs ochraceous to brownish; trochanters often dark anteriorly at bases of femora; femora anteroventrally with darkened longitudinal stripe, apically with dark brown ring that may be interrupted dorsally; tibiae dark brown, dorsal surface with ochraceous stripe from base till three quarters of its length; tarsi dark brown. Mid legs 


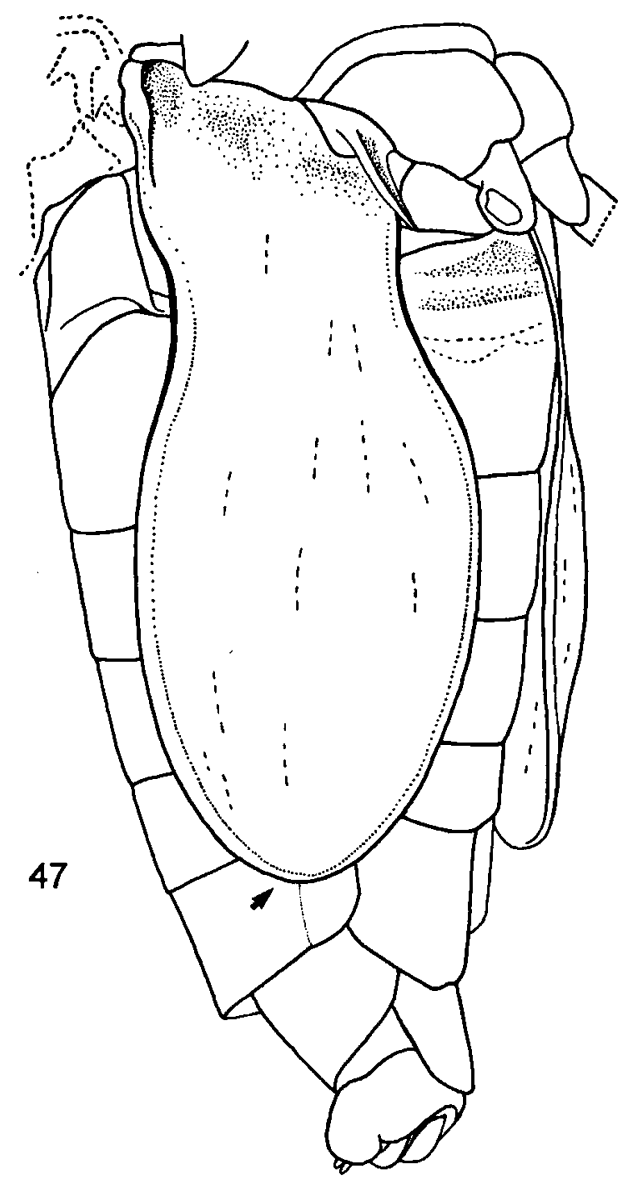

ochraceous; femora sometimes with very indistinct dorsal stripes; tibiae with apical quarter darkened; tarsi dark brown. Hind legs ochraceous; femora sometimes with very indistinct dorsal stripes; tibiae with slightly to distinctly darkened basal ring and with apical third darkened, tarsi ochraceous brown to dark brown. Fore femur with middle spine shorter and more sharply pointed than proximal spine; distal spine small and blunt, distinct; gap between middle and distal spines deep and very narrow. Hind tibia with anteroventral spines having tendency to be placed more distally than in other species of assemblage, causing most distal spine to be reduced in size or even absent.

Male. Operculum (Fig. 47): Long, reaching from just beyond anterior margin to posterior margin of sixth abdominal segment, 2.3-2.5 times as long as

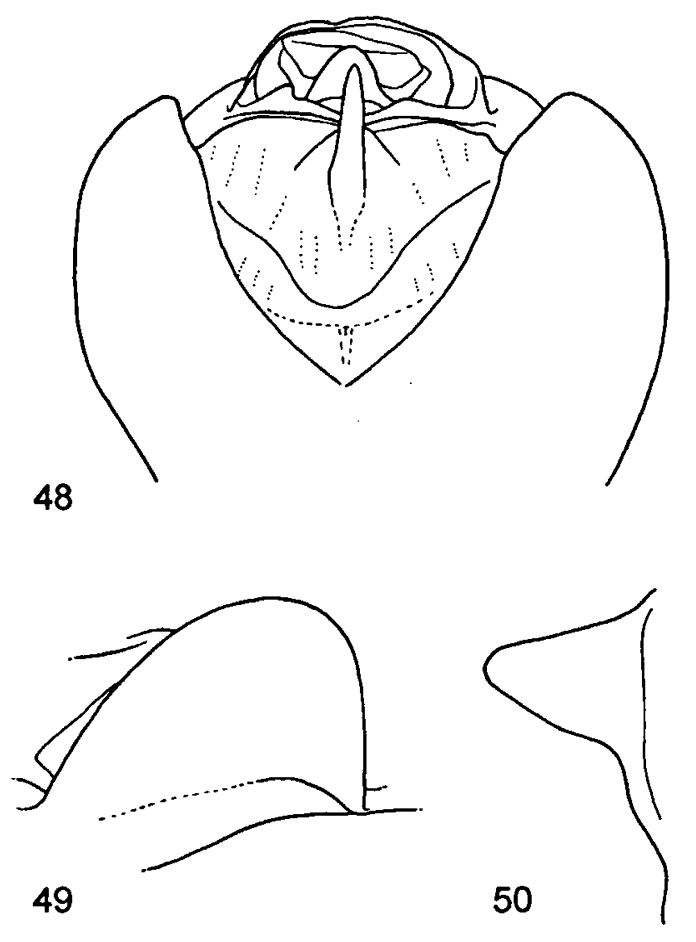

Figs. 47-50. Dundubia nigripes (Moulton, 1923), male: 47, right operculum in lateroventral view, Selangor; 48 , pygofer in dorsal view, Genting Highlands; 49, right timbal covering, Genting Highlands; 50, right katepimeral lobe, Genting Highlands.

maximum width distal of constriction; ochraceous to brownish but sometimes with greenish tinge and with small darker spot close to lateroproximal corner; distal half often somewhat darker than apical half, especially on margin. Medial margin concave near base, convex distal of constriction, sometimes less convex for short distances but never with slightly angular bends. Apex rounded, sometimes slightly angular, tip situated lateral of longitudinal midline of operculum. Lateral margin concave at level of timbal covering, distal of constriction evenly convex to apex. Constriction at $0.3-0.4$ of length of operculum, lateral concavity usually less deep than medial concavity, broadest part of operculum distal of constriction 1.5-1.6 times as wide as minimum width in constriction. Distance between opercula at constrictions 1.2-1.4 times as wide as minimum width in constriction. Opercula at point of closest approximation separated for a 
distance of 0.4-0.6 times maximum width between opercula at constrictions. Surface of operculum distal of constriction convex but only weakly so in longitudinal direction.

Abdomen: Length 1.1-1.2 times that of head and thorax together. Dorsal part of tergites ochraceous brown to almost castaneous; sternites and ventral parts of tergites somewhat lighter but less so on posterior segments. No distinct dark lateral spots on tergites. Posterior margins of tergites 5-7 with short dark spinules, tergite 4 sometimes with very few spinules on lateral part of posterior margin. Timbal covering (Fig. 49) brownish and usually concolorous with mesonotum, about 1.4-1.7 times as wide as long; medial margin immediately curved laterad; mediodistal corner and distal margin broadly rounded; laterodistal corner rounded, lateral margin slightly convex. Sternite 7 with shallow, rounded posteromedial emargination.

Genitalia (Figs. 45-46, 48): Ochraceous brown to brown; dorsal part of pygofer darker than ventral part; uncus lobes usually paler than remainder of uncus but sometimes uncus completely castaneous. Basal pygofer lobes narrow and rounded, well separated from lateral margin of pygofer (Fig. 45); hairs on anteroventral margin long and decreasing in length, both towards basal lobes and towards medial part of area enclosed by anteroventral margin; only very few hairs on pygofer surface anterior of medial part of anteroventral margin. Basal part of uncus rather small and little globose, near bases of uncus lobes with occasional short erect hairs. Uncus lobes narrow and long, divergent from base, no rim around aedeagal opening (Figs. 45-46); medial margin slightly convex to almost straight and curved inwards along whole length, apex tapering and somewhat pointed (Figs. 45-46), lateral margin curved medially at base of uncus lobes, with straight but smooth angle at about one third from medial margin and then running parallel to or slightly convergent with medial margin; distance between apices of uncus lobes greater than distance between lateral margins of basal part of uncus but smaller than width at bases of uncus lobes; uncus lobes with short erect hairs, those near and on bases little longer.

Female. No associated females were found among the material in collections.
Measurements in $\mathrm{mm}\left(\sigma^{\prime}: \mathrm{n}=5\right)$. - Body length: $\sigma^{\prime \prime}: 32.0-34.0$ (32.8 \pm 0.6$)$; head width: $\sigma$ : 11.0-12.1 (11.5 \pm 0.3$)$; maximum pronotum width: $\sigma^{\prime \prime}: 11.6-12.5$ (11.6 0.4$)$; tegmen length: $\sigma$ : $36.5-41.0(38.5 \pm 1.4)$.

Distribution (Fig. 5). - At present it appears that $D$. nigripes is confined to the Malay Peninsula.

Dundubia jacoona (Distant, 1888) n. comb. (Figs. 3, 51-57)

Cosmopsaltria jacoona Distant, 1888: 295; 1889: 47; 1890: pl. $\mathrm{V}$ figs. 3-3b; 1892a: 101; 1892b: xii; 1906b: 56; Moulton, 1911a: 141, 155; 1911b: 185, 189; Distant, 1912b: 44; Moulton, 1917: 2; 1919: 63; 1923: 90, 167; Kato, 1932b: 165. Orientopsaltria jacoona; Kato, 1944a: 7; 1944b: 9; Metcalf, 1963a: 558; Duffels, 1968: 79, 83; 1983: 4, 9; Duffels \& Van der Laan, 1985: 119.

Material examined. - Peninsular Malaysia: Batu Anam [Batu Enam], Johore, xi.1919, $1 \sigma^{\circ}, \mathrm{BMNH}$; Johore, $1 \sigma^{\circ}$ possible syntype Cosmopsaltria jacoona Distant, BMNH; Kuala Lumpur, 19.iv.1922, H.M. Pendlebury, at light, $1 \sigma^{\circ}, \mathrm{BMNH}$; same data, 28.x.1929, 1 ơ $^{\circ}$ BMNH; Malacca, 1890, Plason, 13 o $\sigma^{\circ}$, NHMW; Penang Is., 24.xi.1927, F.N. Chasen, 1 ९, BMNH; same data, 25.x.1927, 1 ơ, BMNH; Port Dickson, Negeri Sembilan, 26.xi.1932, H.M. Pendlebury, 1 \%, BMNH; same data, 4.i.1935, 2 ơ ơ, BMNH; Pressqu'ill de Malacca, 1899, Errington de la Croix \& P. Chapé, 2 o* $\sigma^{\circ}$, MNP; Si Kledang 2650', Perak, 20.xi.1927, E. Seimund, 1 ơ, BMNH; Rompin Mining Co. Railway Track, S.E. Pahang, Petoh swamp, 15.xii.1960, J. Hendrickson, 1 \% , BPBM; same data, 18.xii. 1960, T.C. Maa, 1 \&, BPBM; Rompin Mining Co. Railway Track, 31 km, S.E. Pahang, Petoh swamp, 19.xii.1960, T.C. Maa, 2 o $\sigma$, BPBM; Rompin Mining Co. Railway Track, 19.5 m, S.E. Pahang, Petoh swamp, 19.xii.1960, 1 o', BPBM; Rompin Mining Co. Railway Track, 62 km, S.E. Pahang, 3.iii.1961, T.C. Maa, 1 \&, BPBM; same data, 31 m, 4.iv.1961, K.J. Kuncheria, 1 \% , BPBM; same data, $31 \mathrm{ml}$, 6.iv.1961, 1 \%, ZMA; Tapah, Perak, 1900, G.B. Cerruti, 2 ơ o', MNP.

Borneo: Borneo, $1 \sigma^{\circ}$, BMNH; Borneo, $1 \sigma^{\circ}, \mathrm{MNP}$; Borneo, 1414 91, Chaper, $1 \%$, MNP; Borneo, Müller, 1 \%, RMNH.

East Malaysia: Borneo, Sabah: Forest Camp, $19 \mathrm{~km} \mathrm{~N}$. of Kalabakan, North Borneo (S.E.), 60 m, 19.ix.1962, Y. Hirashima, light trap, 1 \&, BPBM; Forest Camp $12 \mathrm{~m} \mathrm{~N}$. of Kalabakan, Tawau Residency, NB [North Borneo], 200', 19.x.1962, leg. K.J. Kucheria, light trap, $1 \sigma^{\circ}$, BPBM; same data, 1 o , ZMA; Kalabakan, Tawau Residency, N. Borneo, 1415.ix.1958, L.W. Quate \& T.C. Maa, 1 ơ, BPBM; same data, 1 O', ZMA; Kalabakan R., $30 \mathrm{mi}$. West Tawau, Tawau Residency, North Borneo, 9-18.xi.1958, T.C. Maa, 1 ơ, BPBM; [Mount] Kinabalu, N. Borneo, 1 \&, BMNH; Quoin Hill [Gunung Bedung], Cocoa Res. Station, Tawau, North Borneo (S.E.), 1.viii.1962, Y. Hirashima, light trap, 1 \% , BPBM; Quoin Hill [Gunung Bedung], Cocoa Res. Station, Tawau, North 

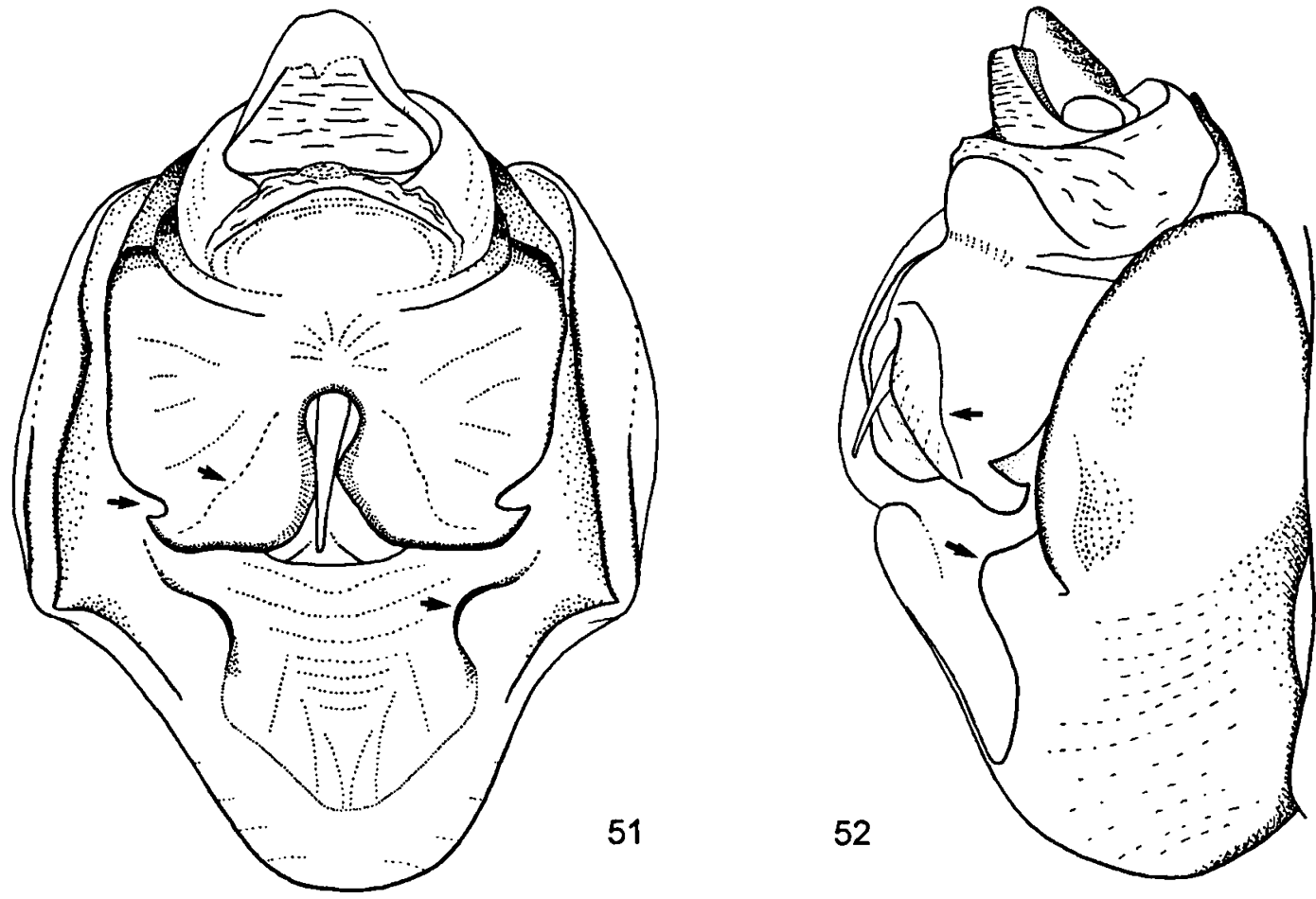

Figs. 51-52. Dundubia jacoona (Distant, 1888), male, Balik Papan: 51, pygofer and uncus in ventral view; 52, pygofer and uncus in lateroventral view.

Borneo (S.E.), 7-12.viii.1962, Y. Hirashima, light trap, 1 ơ, BPBM; Rimidi, R. Labuk, Sandakan Dist., 16-30.ix.1973, C. Pruett, 1 o , BMNH; Sandakan, Nord Borneo, Montano \& Rey, 1 ơ, MNP; Tawau, Cocoa Res. Station, N. Borneo, 28.viii. 1962, Y. Hirashima, light trap, $1 \sigma^{\circ}$, BPBM; Tawau, Brumas Camp, N. Borneo, xi.1974, C. Pruett, 5 o* $\sigma^{\circ}$, BMNH; East Malaysia: Borneo, Sarawak: Julau Lanjak Entimau, 2829.ii.1992, Zaidi, $1 \sigma^{\circ}$, UKMS; foot of Mt. Dulit, junction of rivers Tinjar \& Lejok, 30.ix.1932, B.M. Hobby \& A.W. Moore, $1 \sigma^{\circ}, \mathrm{BMNH}$; W. Melinau Gorge, Gunong Mulu National park, $150 \mathrm{~m}$, iii-iv.1978, J.D. Holloway, 3 \% \%, BMNH.

Brunei: Brunei?, Waterstracht, 2 \% , BMNH; (north) Rampayoh R., lowland forest, 1-3.iii.1982, G.S. Robinson, 2 ơ O’, BMNH.

Indonesia: Borneo, Kalimantan: Balik Papan [Balikpapan], O. K. [East coast] Borneo, 1913, v.d. Bergh, 1 ơ, ZMA; Boelongan [R. Kayan], $1 \circ^{\circ}$, ZMA; Boentok [Buntok], Barito R., Cent. Borneo, G.C. Shortridge, 2 o o', BMNH; Doesonlanden, Wahnes, 1 o, 1 \%, BMNH; Long Bagun [Longbangun], $25 \mathrm{~km}$ S.E. of Longboh, S. Mahakan, Kalimantan Timur, 21.xii.1995, R. Sözer, 1 ơ, ZMA; Samarinda, 24.v.1909, C.A. Lorentz, $1 \sigma^{\circ}$, ZMA; Tanjungisuy [Tanjungisui], Danau Jempang, Kalimantan Timur, 16.v.1996, R. Sözer, 1 o , ZMA; Tiong Buu (= Nahabuan), 18 km N.W. of Longkay [Long Kay], S. Mahakan, Kalimantan Timur, 15.iv.1996, R. Sözer, 1 O", ZMA; Indonesia: Sumatra: Banka vend. [Bangka], xi.1885,

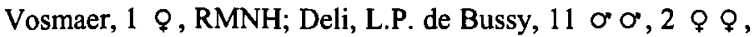

ZMA; same data, 1 O', SEM; Diambi [Jambi], 1909, P. Molenburgh, 3 ơ O०, ZMA; Dolokmerangir [Dolokmaranggir], O.K. [east coast] Sumatra, H.C. van Eldik, 1 o', RMNH; Indragiri, 1893-1894, [van] Hasselt, 4 or $\sigma^{\prime}, \mathrm{RMNH}$; Indragiri, A.L. v. Hasselt, 1895, 1 o", RMNH; Kuala Simpang, N.E. Sumatra, iii.1954, lowland cultivated area, at light, A. Sollaart, 4 o $\sigma^{\circ}, \mathrm{RMNH}$; Namoe Dengas Est., Langkat, E. coast Sumatra, Jourin, 1 \&, MCZ; Padang, Sumatra's Westkust [west coast], E. Jacobson, 1 o", ZMA; Palembang, v.1947, W.C. Verboom, $1 \sigma^{*}, \mathrm{RMNH}$; Sennah Estate, Negerilima [Negerilama], E. C. [east coast] Sumatra, vii.1954, A. Sollaart, lowland, cultivated area, on light, $1 \sigma^{\circ}$, RMNH; Siak, Bluntschli, 1 \%, BMNH; Soesoe [Soesoh], 29.iv.1911, O. Christiane, $1 \sigma^{\circ}$, UZMK; Tenajan, ulu, Sumatra Tengah, 1.x.1959, Ryberg, 1 \&, UZMK; same data, 5.x.1959, 1 o", UZMK.

Locality unknown or not located: Without locality, Swale, 1 o*, BMNH; without locality, 3 ơ o*, RMNH; without locality, v.d. Does de Bye, 1 \&, RMNH; 'Cochin Chine and Sumatra', 1902, Beauvais, 1 o , MNP; Oost Indië [East Indies], [illegible] 1910, Clei... [remainder illegible], $10^{\circ}$, ZMA.

Remarks. - In the original description it is stated that the material is deposited in the Calcutta $\mathrm{Mu}$ seum, but it is not indicated of how many specimens the type series consists. According to 


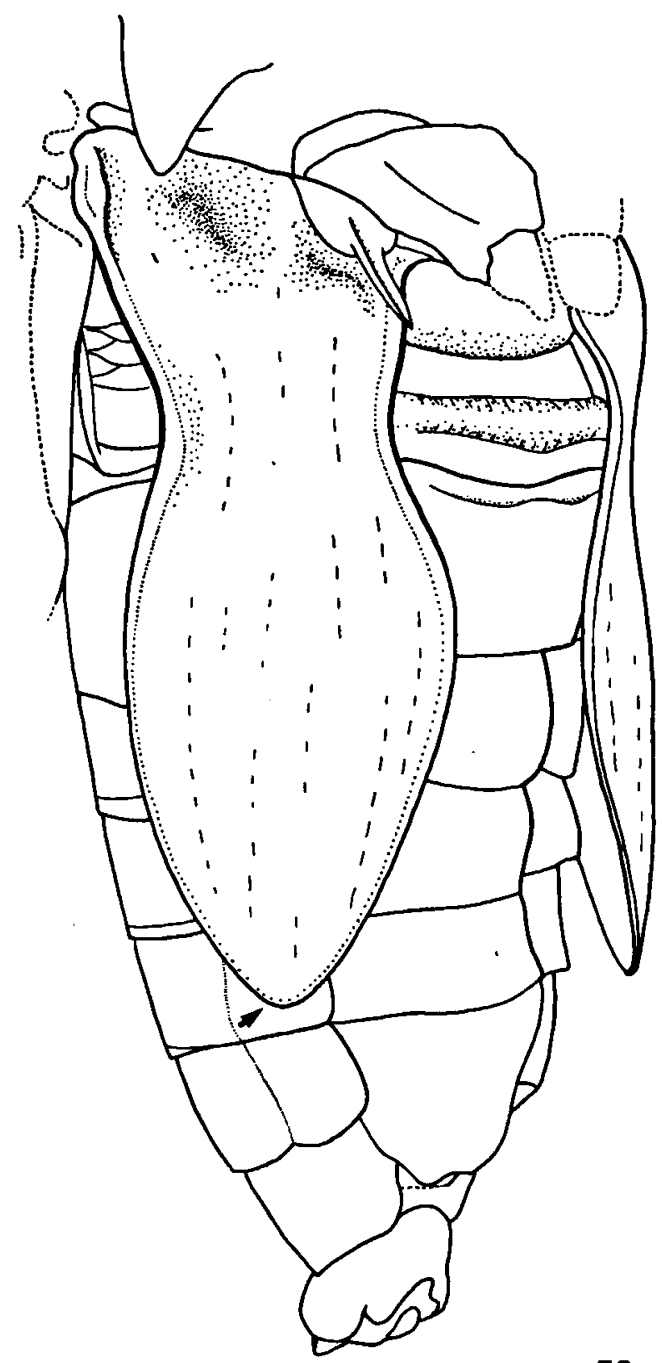

53
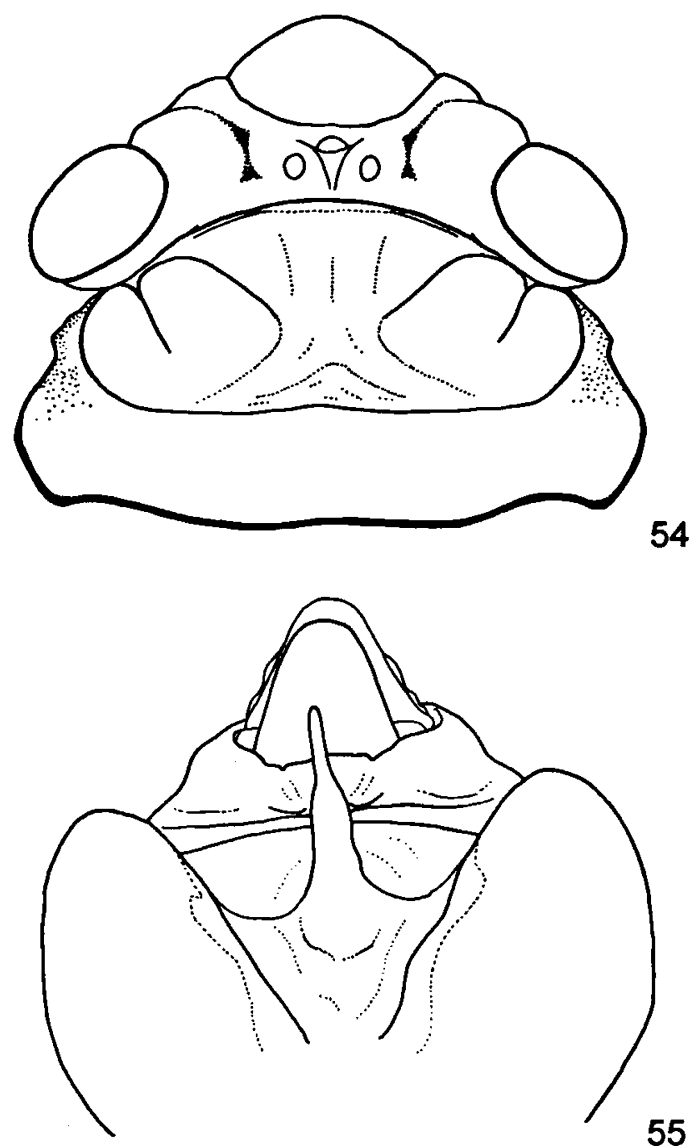

55

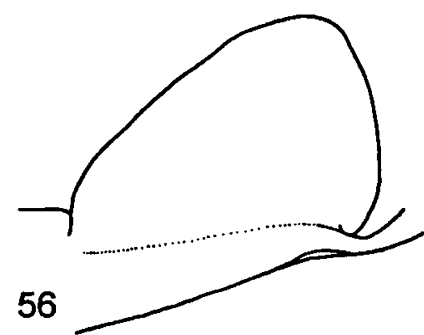

Figs. 53-57. Dundubia jacoona (Distant, 1888), male: 53, right operculum in lateroventral view, Balik Papan; 54, head and pronotum in dorsal view, Balik Papan; 55, pygofer in dorsal view, Indragiri; 56, right timbal covering, Balik Papan; 57, right katepimeral lobe, Balik Papan.

Moulton (1911a: 141) the type could not be found in the Calcutta Museum. Later Moulton (1923: 90) notes that two males from Johore and Borneo in the BMNH are labelled as types. Both specimens still remain there. There is no record or indication that the material was transferred from Calcutta to the $\mathrm{BMNH}$, so it is doubtful that this specimen from Johore represents a syntype. The specimen from Borneo mentioned cannot have belonged to the type series since $D$. jacoona was described from Johore only.

D. jacoona has a distinct pattern of darker and lighter parts on head and pronotum. In collection specimens the darker parts are brownish to castaneous, the lighter part greenish to dark ochraceous. In contrast to the other species of the $D$. jacoona 
assemblage the paramedian fasciae are never black but at most darker brown than the remainder of the mesonotum.

Description. - Body brownish with ochraceous or greenish markings on head and lighter brownish markings on pronotum; abdomen more castaneous; underside of body often lighter.

Head (Fig. 54): Postclypeus brownish with anteromedial spot and area anterior of frontoclypeal suture ochraceous or greenish, in frontal view with lighter brownish areas of variable size lateral of anteromedial spot. Anteclypeus brownish with a lighter median fascia. Vertex ochraceous or greenish but medially and on vertex lobes brownish. Head otherwise brownish. Suture between vertex lobe and supra-antennal plate consisting of small depression near anterior margins of plates, depression merging only seldom with longitudinal groove running along lateral part of frontoclypeal suture and between eye and lateral ocellus. Frontoclypeal suture trapezoid with medial part wider than distance between lateral margins of lateral ocelli, sometimes corners between lateral and medial parts rounded. Rostrum brownish but darker near apex, either just or just not reaching between hind coxae.

Thorax: Maximum width of pronotum just exceeding maximum width of head (Fig. 54). Pronotal disc brown but usually ochraceous or greenish on broad medial area, anterior margin and medial part of medial and lateral lobes; medial spot immediately in front of pronotal collar indistinct or absent. Pronotal collar (Fig. 54) either dark brown, often with almost imperceptible lateral spots, or more ochraceous brown, sometimes with greenish tinge and usually with darker lateral spots and occasionally also brown spots posterior of lateral lobe of pronotal disc. Anterior corner of pronotal collar rather broad and rounded, sometimes more angular; lateral tooth short and blunt; posterior corner broad, laterally smoothly rounded, posteriorly slightly angular. Mesonotum brownish to castaneous, either unicolorous or with indistinct paramedian fasciae medial of mesonotal fissures and with paler fasciae lateral of fissures; when disc between paramedian fasciae lighter than remainder of disc then often median fascia present, very narrow near anterior margin and widening posteriorly. Katepimeral lobe (Fig. 57) shorter than or as long as basal width; dorsal margin almost straight to somewhat convex; apex rounded but sometimes almost angular; ventral margin concave near base, then straight and weakly convex near apex. Surface of katepimeral lobe concave on dorsal half, flat to slightly convex on ventral half and densely covered with short hairs, hairs on ventral margin somewhat longer. Apex of katepimeral lobe extending over base of operculum.

Tegmina and wings: Tegmina hyaline but often somewhat brownish, especially distally, and with a more or less distinct brownish reticulation visible between veins in distal part; basal veins of second and third apical cells occasionally slightly infuscate; basal cell of tegmen partly or completely ochraceous. Veins of tegmen brownish, cubital veins and first anal vein paler. Wings hyaline; veins brownish, medial vein paler.

Legs: Coloration rather variable. Fore legs generally brownish; femora with lighter ill-defined markings basally and medially. Mid legs ochraceous to light brownish, somewhat darker dorsally; femora anteriorly with a preapical brown spot; tibiae darker at base and apex; tarsi brownish. Hind legs ochraceous to brownish; femora anteriorly and posteriorly with a preapical brown spot; tibiae narrowly darkened at base. Fore femur with proximal and middle spines, rather broad and pointed and of equal length; distal spine very small but distinct and somewhat pointed; gap between middle and distal spines deep.

Male. Operculum (Fig. 53): Long, reaching from halfway sixth to slightly beyond anterior margin of seventh abdominal segment, 2.4-2.7 times as long as maximum width distal of constriction; brownish. Medial margin concave near base, convex from about one third of its length, straight or only slightly convex close to apex. Apex rather angularly rounded, tip situated lateral of longitudinal midline of operculum. Lateral margin concave at level of timbal covering and somewhat beyond, distal of constriction convex to apex. Constriction at 0.3-0.4 of length of operculum, medial and lateral concavities about equally deep, broadest part of operculum distal of constriction 1.3-1.5 times as 
wide as minimum width in constriction. Distance between opercula at constrictions 1.2-1.4 times as wide as minimum width of opercula in constriction. Opercula at point of closest approximation separated for a distance of (0.4) 0.5-0.7 times maximum width between opercula at constrictions. Surface of operculum distal of constriction curved around abdomen at lateral margin, hardly convex in longitudinal direction.

Abdomen: About as long as head and thorax together. Dorsal part of tergites brownish to castaneous, sternites and ventral parts of tergites lighter. Posterior margins of tergites 5-7 with short dark spines, spines increasing in number and length from tergite 5 to 7 . Timbal covering (Fig. 56) almost triangular, at base about or slightly more than 1.25 times as wide as long; medioproximal corner with an acute angle; distal margin oblique and only weakly convex; laterodistal corner rounded; lateral margin almost straight to somewhat convex. Sternite 7 shallowly emarginate posteromedially.

Genitalia (Figs. 51-52, 55): Ochraceous brown to brown; dorsal part of pygofer darker than ventral part; uncus usually more castaneous along lateral margins of uncus lobes and on basal part. Basal pygofer lobes in ventral view angularly rounded (Fig. 51). Basal part of uncus semicircular and globose and with some erect hairs near bases of uncus lobes (Fig. 51). Uncus lobes rounded at medial and distal margins and somewhat curved inwards; lateral margins indented rather close to laterodistal corner, anterior corner of indentations with a blunt tooth, posterior corner of indentations rounded (Fig. 51); surface with a shallow, Ushaped groove around aedeagal opening from which shallow grooves are usually radiating (Fig. 51); bases of lobes with some erect hairs. Maximum width of uncus lobes at laterodistal corners less than width at bases.

Female. Operculum brownish and somewhat paler than anterior sternites, just reaching beyond anterior margin of third abdominal segment, curved around abdomen laterally. Rather variable in shape, lateral margin distal of lateroproximal lobe convex; laterodistal corner somewhat angular, produced further posteriorly than mediodistal corner; mediodistal corner rounded but somewhat an- gular when distal margin more straight and oblique.

Abdomen: Length 0.9-1.0 times that of head and thorax together. Dorsal part of tergites brownish to castaneous; sternites and ventral parts of tergites lighter. Posterior margins of tergites 3 and 4 with very short dark spines but spines medially more sparse, posterior margins of tergites 5-7 with spines along whole length, those on tergite 7 longer; posterior margin of tergite 8 with scattered spines medially. Tergites 4-6 with some scattered spine-like setae near lateral margin. Sternite 7 with rounded posteromedial emargination of variable width and depth.

Genitalia: Dorsal and ventral parts of pygofer concolorous with dorsal and ventral part of abdomen; ovipositor sheath dark castaneous brown. Dorsal margin of pygofer in lateral view slightly concave, ventral margin just the slightest bit convex. Ovipositor sheath shorter than or reaching just as far as caudodorsal beak; anal valve not reaching further than either ovipositor sheath or caudodorsal beak.

Measurements in $\mathrm{mm}\left(\sigma^{\prime \prime}: \mathrm{n}=7\right)$. - Body length: $\sigma^{\circ}: 33.0-37.5$ (35.7 \pm 1.8$)$, ᄋ : 35.0-39.5 (36.9 \pm 1.1$)(\mathrm{n}=7)$; head width: $\sigma^{\prime}$ : 12.1-13.8 (13.0 \pm 0.6$)$, ᄋ : 13.1-14.3 (13.6 \pm 0.4$)(n=7)$; $\operatorname{maxi}-$ mum pronotum width: $\sigma^{\circ}: 12.2-13.9(13.3 \pm 0.7)$, $९: 13.2-14.8$ $(14.1 \pm 0.6)(n=7)$; tegmen length: $o^{\prime}: 41.0-49.0(44.8 \pm 2.4)$, ᄋ : $43.5-49.0(47.2 \pm 1.5)(n=5)$.

Distribution (Fig. 3). - The distribution of $D$. jacoona covers Borneo, Sumatra, and the southern part of the Malay Peninsula. The record from New Guinea (Moulton, 1923) is doubtful and could not be confirmed.

Dundubia oopaga (Distant, 1881) n. comb. (Figs. 4, 58-64)

Cosmopsaltria oopaga Distant, 1881: 640; 1883: 171; Atkinson, 1884: 227; 1886: 169; Distant, 1888: 295; 1889: 46, 47; 1890: pl. V figs. 9-9b; 1892b: xii; Noualhier, 1896: 254; Noualhier \& Martin, 1904: 179; Distant, 1906a: 97, fig. 45; 1906b: 56; 1912b: 44; 1917a: 101; Kato, 1932b: 165; Metcalf, 1963a: 552; Duffels \& Van der Laan, 1985: 136.

Cosmopsaltria oopaqa [sic!]; Mitra \& Muraleedharan, 1976: 139.

Orientopsaltria oopaga; Duffels, 1983: 9.

Cosmopsaltria andersoni Distant, 1883: 170 (n. syn.); Atkinson, 1886: 171; Distant, 1889: 46; 1890: pl. V figs. 6-6b; 
1892b: xii; *Horváth, 1898: 554; Distant, 1906a: 99; 1906b: 56; Oshanin, 1906: 3; Kirkaldy, 1907: 306; Oshanin, 1908: 387; Distant, 1912b: 45; 1917a: 101; Moulton, 1923: 87, 90, 167; Kato, 1932b: 165, pl. XXV fig. 3; Metcalf, 1963a: 545.

Terpnosia andersoni; Wu, 1935: 17 (partim; erroneously considered $D$. andersoni and $T$. andersoni to be the same species).

Orientopsaltria andersoni; Duffels, 1983: 9.

Not: Cosmopsaltria oopaga: Ishihara, 1961: 225, pl. 2 fig. 9 (= Platylomia sp.).

Lectotype designation and synonymy. - $D$. oopaga was described from Burma without designation of a type specimen and without indication of the number of specimens involved. No further notes about possible type material were consequently published. The only specimen representing the type series is a male deposited at the BMNH bearing the following labels: 'Type' [printed on round label with red margin], 'Burmah' [handwritten], 'oopaga / Dist.' [Distant's handwriting], 'Distant Coll. / 1911-383.' [printed]. This specimen is herewith designated as lectotype (ICZN Recommendation 73F) and is labelled accordingly.

D. andersoni was likewise described without designation of a type specimen and without indication of the number of specimens involved. At the BMNH a male is deposited bearing the following labels: 'Type' [printed on round label with red margin], 'Mergui' [handwritten], 'andersoni / (type) Dist.' [Distant's handwriting], 'Distant Coll. / 1911-383.' [printed]. This specimen represents the only known specimen of the type series and is herewith designated as lectotype (ICZN Recommendation 73F) and labelled accordingly.

$D$. oopaga and $D$. andersoni have always been considered to be separate species differing in body size, length of opercula, and rostrum. In most earlier publications (e.g. Distant, 1883, 1889,1906 a) very little material was available for comparing these species and the possibility of a variable species could not be investigated. Examination of larger numbers of specimens from different localities has shown now that the characters given to separate $D$. oopaga and $D$. andersoni are variable. The relative length of the opercula appears to be more or less correlated with body length: larger specimens have opercula extending less far along the abdomen. Since no differences in the genitalia could be found, D. oopaga and $D$. andersoni are considered to be synonymous.

Material examined. - Vietnam: Chapa [Cha Pai], Tonkin, vvi.1916, R.V. de Salvaza, $1{ }^{\circ}$, BMNH; Cochin Chine, 1831, Delestre, 189 91, 1 o , BMNH; same data, 188 91, 1 \&, MNP; Saigon [Ho Chi Minh], Swale, 1 \&, BMNH; Sang-Bé [Song Be], 1878, Harmand, 1051 78, 1 ơ, 1 \%, MNP.

Cambodia: Cambodge, 1 O०, MNP; Cambodge, 1886, A. Pavie, 2871 86, $1 \sigma^{\circ}$, BMNH; Cambodge, 1886, A. Pavie, 2871 86, 2 ơ Ơ, MNP.

Laos: Vientiane, 22.ix.1919, R.V. de Salvaza, $1 \sigma^{\circ}, \mathrm{BMNH}$; same data, 23.x.191, $1 \sigma^{\circ}, \mathrm{BMNH}$.

Burma: Burmah, lectotype o Cosmopsaltria oopaga Distant, BMNH; Burmah, Hough, 1 ९, BMNH; Mergui, lectotype ơ Cosmopsaltria andersoni Distant, BMNH; Moulmein, Hood, $1 \sigma^{\circ}, \mathrm{BMNH}$.

Thailand: Chiangmai [Chiang Mai] X-51-136, D. \& E. Thurman, $1 \sigma^{\circ}$, USNM; Ban-tin-doi, Chiengmai [Chiang Mai], 310 m, 13.xi.1957, J.L. Gressitt, Malaise trap, $1 \sigma^{\circ}$, BPBM; Nakom Phenom [Nakhon Phanom], 28.x.1971, W.P. Morrison, black-light trap, 1 o*, MNP; North Thailand, Doi Suthep, ix.1958, B. Degerbøl, Pr. 1322 (1.7.59), 1 o*, UZMK; Payao [Phayao] 8-31-51-90, D. \& E. Thurman, 1 o", USNM; Siam, 1886, Pavie, 1792 86, 1 \%, BMNH; prov. Pachim [Prachin Buri], J.M. Bel, 195-95, 1 O', MNP; South-east Thailand, Chanthaburi, foot of Khao Soi Dao, $200 \mathrm{~m}, 12$ xi.1969, R.J. van Beusekom, 1 o*, RMNH; S. Siam, H. Wey, 1 o , BMNH; Sakarat [Ban Huai Sakae Rat], Plateau van Khorat [Khorat Plateau], $400 \mathrm{~m}, 30 . x .1969$, R.J. van Beusekom, 1 \%, 1 \%, RMNH.

Peninsular Malaysia: Kuala Lompat, Pahang, 30.i-1.ii.1993, Hanjani, $1 \sigma^{\circ}$, UKMS; Penang, $1 \sigma^{\circ, 1}$ \&, collected in cop., 17.xii.1948, H.T. Pagden \& K.C. Cheang, BMNH; same data, 5.ii.1966, H.T. Pagden, 1 \%, BMNH.

Indonesia, Sumatra: Sumatra, St. Pol-Lias 1082-80, 1 o , MNP.

Uncertain location: Indochina, R. Vitalis, $1 \sigma^{\circ}, \mathrm{BMNH}$.

Remarks. $-D$. oopaga is the only species of the $D$. jacoona assemblage with an extensive pattern of black markings on head and thorax (Fig. 61) and a rostrum that extends beyond the hind coxae. The male genitalia most resemble those of $D$. jacoona but differ in having a more posteriorly situated indentation in the lateral margin of the uncus lobe and less strongly developed basal pygofer lobes (Fig. 58).

Description. - Body ochraceous to brownish, mesonotum sometimes more olivaceous; head, pronotum and mesonotum with black markings.

Head (Fig. 61): Postclypeus ochraceous brown, anteromedial spot enclosed by U-shaped black band which extends laterally towards eyes immediately ventral of supra-antennal plates and vertex lobes, postclypeus in ventral view either with or without narrow dark median band from anteromedial spot to clypeal suture. Anteclypeus darkened laterally, shape of markings and degree of darkening variable. Vertex (Fig. 61) ochraceous with diffuse black spot enclosing ocelli, area between lateral ocelli and eyes either without further markings, with small isolated brown or black spots or with diffuse black spots extending onto vertex lobes. Head otherwise ochraceous to brownish. Suture between vertex lobe and supra-antennal 

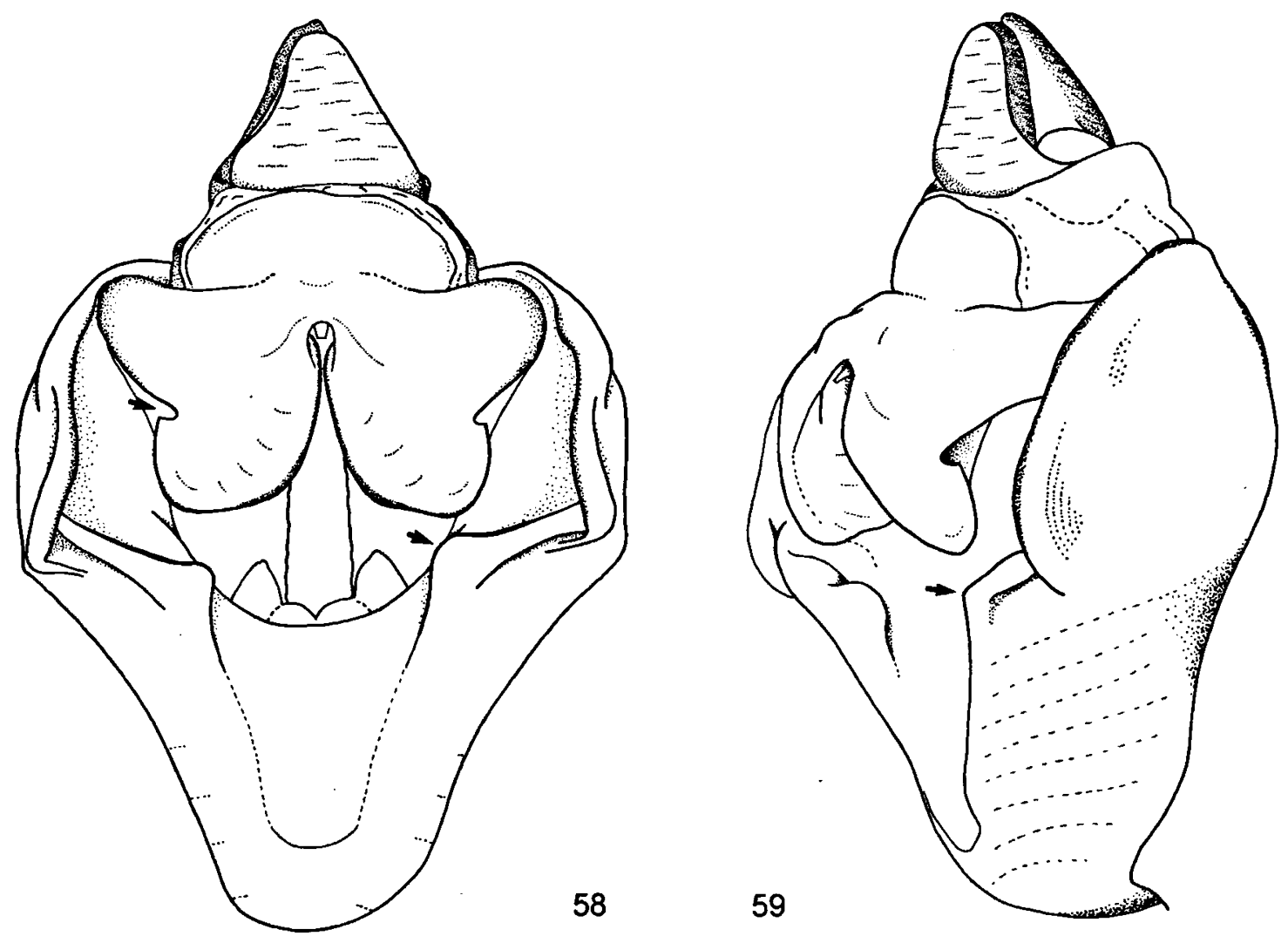

Figs. 58-59. Dundubia oopaga (Distant, 1881), male, Nakom Phenom: 58, pygofer and uncus in ventral view; 59, pygofer and uncus in lateroventral view.

plate distinct and merged with longitudinal groove running along lateral part of frontoclypeal suture and between eye and lateral ocellus. Frontoclypeal suture trapezoid, medial part wider than distance between lateral margins of lateral ocelli. Rostrum ochraceous but darkened from posterior coxae onwards, long, only just not reaching halfway sternite 2.

Thorax: Pronotum (Fig. 61) distinctly broader than head. Pronotal disc ochraceous, central fasciae black and widened anteriorly; anterior oblique fissures black near anterior margin and near central fasciae; posterior oblique fissures darkened, anterolateral corner of lateral lobe of pronotal disc black. Pronotal collar (Fig. 61) ochraceous with brown or black spots in middle of lateral part; anterior margin with some very short, thick, dark spiny bristles and anterior corner with short blunt lateral tooth, posterior corner smoothly rounded. Meso- notum ochraceous, brown or olivaceous brown, median fascia darkened on anterior half of disc; anterior half of disc with paramedian fasciae black, fasciae narrow near anterior margin of mesonotum, widening towards middle and then curved towards and usually fusing with median fascia, enclosing two light obconical spots; anterior margin laterally of paramedian fasciae often with small triangular black markings; paramedian fasciae on posterior half of disc represented by black spots immediately anterior of apices of anterior arms of cruciform elevation; lateral fasciae not reaching anterior margin of mesonotum and often interrupted about halfway. Katepimeral lobe (Fig. 64) generally narrow, longer than basal width; dorsal margin almost straight on basal half, then convex; apex narrowly rounded but sometimes slightly angular; ventral margin concave near base and almost straight on apical half; lobe narrowing 

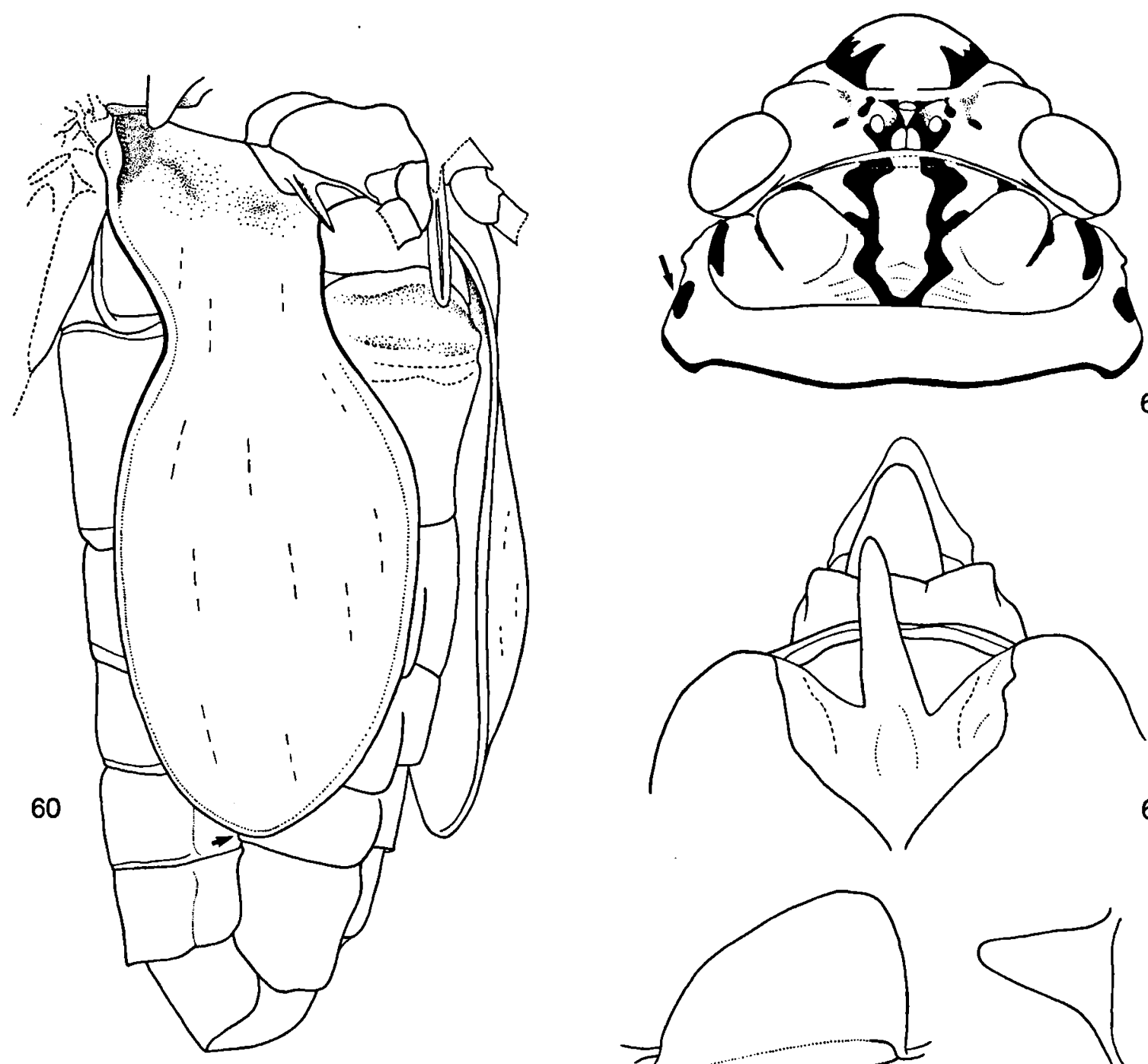

61
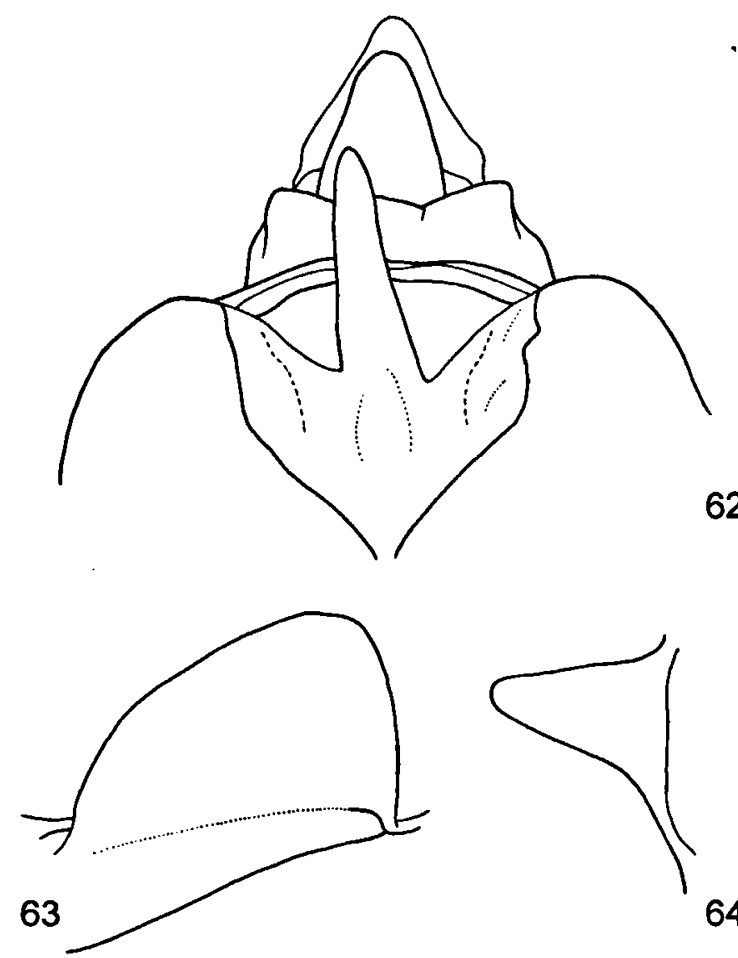

Figs. 60-64. Dundubia oopaga (Distant, 1881), male: 60, right operculum in lateroventral view, Nakom Phenom; 61, head and pronotum in dorsal view, Nakom Phenom; 62, pygofer in dorsal view, Cambodge; 63, right timbal covering, Nakom Phenom; 64, right katepimeral lobe, Nakom Phenom.

close to base. Surface of katepimeral lobe slightly concave on dorsal half and densely covered with short hairs and waxy coating, hairs on margins somewhat longer and interspersed with occasional long hairs. Apex of katepimeral lobe just extending over base of operculum.

Tegmina and wings: Tegmina hyaline, sometimes somewhat brownish distally and with indis- tinct brownish reticulation between veins in distal part; basal veins of second and third apical cells almost imperceptibly infuscate; basal cell infuscate. Veins of tegmen brownish, darker around corial fold and at bases and apices of apical cells. Wings hyaline; veins dark brownish but lighter on cubital veins and distal part of medial vein.

Legs: Fore legs ochraceous; trochanters bor- 
dered black anteriorly at bases of femora; femora anterodorsally with small black basal spot, anteriorly and posteriorly with preapical black spots that sometimes form a ring, anteroventrally with darkened longitudinal stripe; tibiae anteriorly with dark longitudinal stripe which is absent near base, posteriorly with dark longitudinal stripe that widens apically and merges dorsally with anterior stripe, ventrally darkened near apex; tarsi dark brownish. Mid legs ochraceous; femora anteriorly either with or without an elongated preapical black spot; tibiae with dark basal and apical rings, posteriorly with dark longitudinal stripe on apical half; tarsi dark brownish. Hind legs ochraceous; tibiae with black basal ring. Fore femur with proximal and middle spines of about equal length, slender and sharply pointed; distal spine very small but distinct and blunt; gap between middle and distal spines deep.

Male. Operculum (Fig. 60): Long, reaching from just beyond middle of sixth to almost posterior margin of seventh tergite, 2.2-2.6 times as long as maximum width distal of constriction; ochraceous with dark lateroproximal spot, sometimes darker apically. Medial margin concave near base, convex from about one third of its length, sometimes less convex for short distances and then with slightly angular bends. Apex rounded to somewhat angularly rounded, tip lateral of longitudinal midline of operculum. Lateral margin concave at level of timbal covering and somewhat beyond, distal of constriction evenly convex to apex. Constriction at $0.2-0.3$ of length of operculum, medial concavity less deep than lateral concavity, broadest part of operculum distal of constriction 1.6-1.9 times as wide as minimum width in constriction. Distance between opercula at constrictions 1.4-1.7 times as wide as minimum width in constriction. Opercula at point of closest approximation separated for a distance of 0.3-0.5 times maximum width between opercula at constrictions. Surface of operculum distal of constriction evenly convex.

Abdomen: Length 1.1-1.3 times that of head and thorax together. Tergites and sternites ochraceous to brownish, anterior segments lighter ventrally.
Tergites 3-6 with brown spots along dorsolateral margin. Posterior margins of tergites 5-7 with short dark spines, spines increasing in number and somewhat in length from tergite 5 to 7 . Timbal covering (Fig. 63) ochraceous, at base 1.5 times as wide as long; medial margin curved sideways; distal margin oblique, almost straight and laterodistal corner smoothly rounded, lateral margin straight or slightly convex. Sternite 7 shallowly emarginate posteromedially.

Genitalia (Figs. 58-59, 62): Pygofer and uncus ochraceous, dorsal part of pygofer and uncus often somewhat darker. Basal pygofer lobes distinct and rather angular, widely separated from lateral margins of pygofer (Fig. 58); hairs on basal lobes shorter than those on inner ventral margin. Basal part of uncus semicircular and globose (Fig. 58) and with some erect hairs near bases of uncus lobes. Uncus lobes at medial and distal margins rounded and curved inwards; lateral margins indented, anterior corner of indentations rather acutely angular, posterior corner of indentations rounded (Fig. 58); bases of uncus lobes with some erect hairs, lateral hairs longer than those more medially. Width at laterodistal corners of uncus lobes less than width at bases.

Female. Operculum greenish or ochraceous to brownish and darker medially, just reaching beyond base to almost halfway sternite 3 , curved around abdomen laterally. Lateral margin distal of lateroproximal lobe straight but somewhat convex near laterodistal corner; laterodistal corner rounded; distal margin convex but almost straight for a short distance medially; mediodistal corner broadly rounded; medial margin very short.

Abdomen: About 0.9 times as long as head and thorax together. Dorsal part of tergites brownish, posterior segments somewhat darker; sternites and ventral parts of tergites lighter. Tergites 3-6(7) near lateral margin with darker spots, tergites 3-6 with pairs of darker paramedian spots which are situated progressively more laterally on posterior tergites, meeting lateral spots on tergite 6. Posterior margins of tergites 3 and 4 with some short and slender dark spines except medially; posterior 
margins of tergites 5-7 with more numerous and longer spines, especially on tergite 7 ; posterior margin of tergite 8 with scattered spines medially. Sternite 7 with an almost triangular posteromedial emargination which is rather variable in width, posterior margin at site of emargination darkened.

Genitalia: Dorsal part of tergite 9 almost castaneous, ventral part brownish; distal part of ovipositor sheath brown to dark brown. Dorsal margin of pygofer in lateral view slightly concave, ventral margin somewhat convex. Ovipositor sheath about reaching as far as apex of caudodorsal beak, anal valve slightly shorter.

Measurements in $\mathrm{mm}(\varphi: \mathrm{n}=3)$. - Body length: $\sigma^{\circ}: 31.5-38.5$ $(34.6 \pm 1.8)(n=12), \%: 33.0-34.5(34.0 \pm 0.6)$; head width: $\sigma^{\prime}:$ 10.6-12.1 (11.4 \pm 0.4$)(\mathrm{n}=12)$, $:$ : 11.8-12.4 (12 \pm 0.2$)$; maximum pronotum width: $\sigma:$ : 11.2-13.3 $(12.3 \pm 0.6)(\mathrm{n}=12)$, ᄋ : 12.2-13.9 (12.8 \pm 0.7); tegmen length: $\sigma$ : $36.5-42.5$ (40.5 \pm 1.3) $(\mathrm{n}=11)$, $९: 41.5-43.0(42.5 \pm 0.7)$.

Distribution (Fig. 4). - Widespread in Indo-China (Burma, Cambodia, Laos, Thailand, Vietnam), and also found on the Malay Peninsula and Sumatra. This species was also recorded from the Andaman and Nicobar Islands (Mitra \& Muraleedharan, 1976), and Jiangsu and Anhui in China (Oshanin, 1906; Horváth, 1898*) but these records could not be confirmed. The specimen from Sumatra represents the first record from this island.

Metcalf (1963a) also lists India and the Malay Archipelago. He erred in citing India instead of Mergui as locality given by Atkinson (1886). The record from the Malay Archipelago ascribed to Moulton (1923) is the result of a misinterpretation.

Biological notes. - A label on a specimen collected in Penang, Peninsular Malaysia (BMNH) describes the song as 'the most ear-piercing song, a cross between an electric bell and a steam whistle'. This specimen bears the note that specimens of this species were observed on Lagerstroemia, Andira, Adinathera and Pterocarpus, and specimens copulating on Lagerstroemia floribunda were collected (see Material examined above). The specimens sit high upon the trunks and branches and are difficult to spot. The male from Ban Huai Sakae Rat was collected in mixed dipterocarp forest.
Dundubia ayutthaya n. sp.

(Figs. 4, 65-71)

Material examined. - Holotype: 'Hoopbon / nr Sriracha / S.E. Siam', 'Hugh Smith / coll 11-3-31', O', USNM. Paratypes: Thailand: Hoopbon nr. Sriracha [Hubbon nr. Siracha], S.E. Siam, 11-3-31 [probably 3.xi.1931], H. Smith, 10 ơ o*, USNM; same data, $5 \sigma^{\circ} \sigma^{\circ}$, ZMA; foot of Khao Soi Dao, Chanthaburi, Southeast Thailand, $200 \mathrm{~m}, 12 . x i .1969$, R.J. van Beusekom, 1 o , RMNH.

Other material examined. - Thailand: Khao Soi Dao, 22.xi.1987, M.G. Allen, 3 ㅇ \& , BMNH; same data, 1 \% , ZMA.

Remarks. - D. ayutthaya is closely related to $D$. jacoona and D. oopaga. This is most clear from the structure of the uncus lobes (compare Figs. 58 and $65)$. On first glance the more fully coloured specimens of $D$. ayutthaya look like not fully coloured specimens of $D$. oopaga but they are smaller and can be most readily separated from the other two species by the narrow katepimeral lobe (Fig. 71).

Description. - Small species with narrow head; body olivaceous to ochraceous or ochraceous brown; pronotum and mesonotum virtually without markings or mesonotum with indistinct paramedian fasciae and/or brown markings near posterior margin.

Head (Fig. 68): All parts ochraceous to ochraceous brown, only frontoclypeal suture with pair of narrow dark transverse stripes. Vertex lobes and supra-antennal plates narrow, less than half width of postclypeus. Suture between vertex lobe and supra-antennal plate distinct, almost reaching anterior margin of vertex, continuing posteriorly between eye and lateral ocellus and with short branch towards frontoclypeal suture. Frontoclypeal suture trapezoid, medial part wider than distance between lateral margins of lateral ocelli. Rostrum ochraceous, narrowly darkened from posterior coxae onwards, just reaching base of hind coxae.

Thorax: Pronotum wider than head, also at level of lateral teeth of pronotal collar (Fig. 68). Pronotal disc ochraceous, just narrower than head; medial spot immediately in front of pronotal collar distinct (Fig. 68). Pronotal collar ochraceous to partly olivaceous, slightly darkened near anterolateral corner; black posterior margin sometimes less distinct between posterior corners and medial 

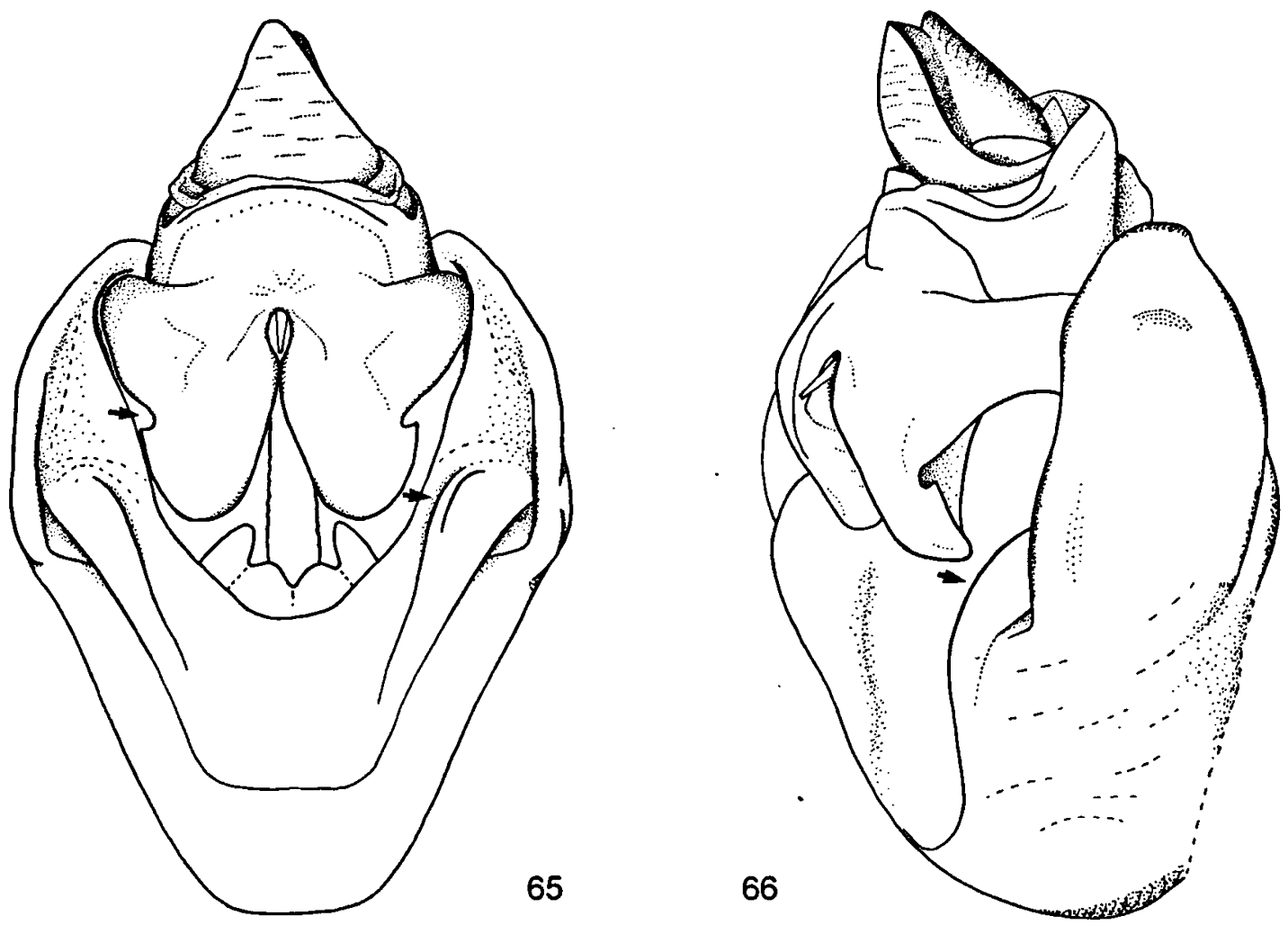

Figs. 65-66. Dundubia ayutthaya n. sp., male, holotype: 65, pygofer and uncus in ventral view; 66, pygofer and uncus in lateroventral view.

part (as in Fig. 68); anterior margin broadly rounded; lateral teeth broad and blunt. Mesonotum ochraceous to ochraceous brown, sometimes somewhat olivaceous; paramedian fasciae sometimes brownish and indistinct but usually absent; sometimes indistinct brownish spots in posterolateral corners of disc and in front of anterior arms of cruciform elevation. Katepimeral lobe (Fig. 71) very narrow, more than twice as long as basal width; dorsal margin concave at extreme base, then straight to convex; apex rounded and curved ventrad; ventral margin concave from base to apex. Surface of katepimeral lobe concave on dorsal half, flat on ventral half and covered with short hairs and waxy coating, hairs along ventral margin long but shortening towards apex. Apex of katepimeral lobe just extending over base of operculum.

Tegmina and wings: Tegmina hyaline and with indistinct brownish reticulation between veins in distal part; basal cell slightly yellowish infuscate. Veins of tegmen ochraceous, darker around corial fold. Wings hyaline; veins ochraceous.

Legs: Ochraceous, tarsi slightly darker. Fore femur with middle spines triangular and pointed, just over half as long as proximal spine; distal spine very small and blunt; gap between middle and distal spines shallow and broad.

Male. Operculum (Fig. 67): Long, reaching from just not to middle of sixth to just beyond middle of seventh tergite, 2.4-2.8 times as long as maximum width distal of constriction, ochraceous. Medial margin concave near base, convex from about one third of its length to apex. Apex rounded, tip situated lateral of longitudinal midline of operculum. Lateral margin concave at level of timbal covering and somewhat beyond; distal of constriction convex to apex although sometimes almost straight at about middle. Constriction at 0.3-0.4 of length of 


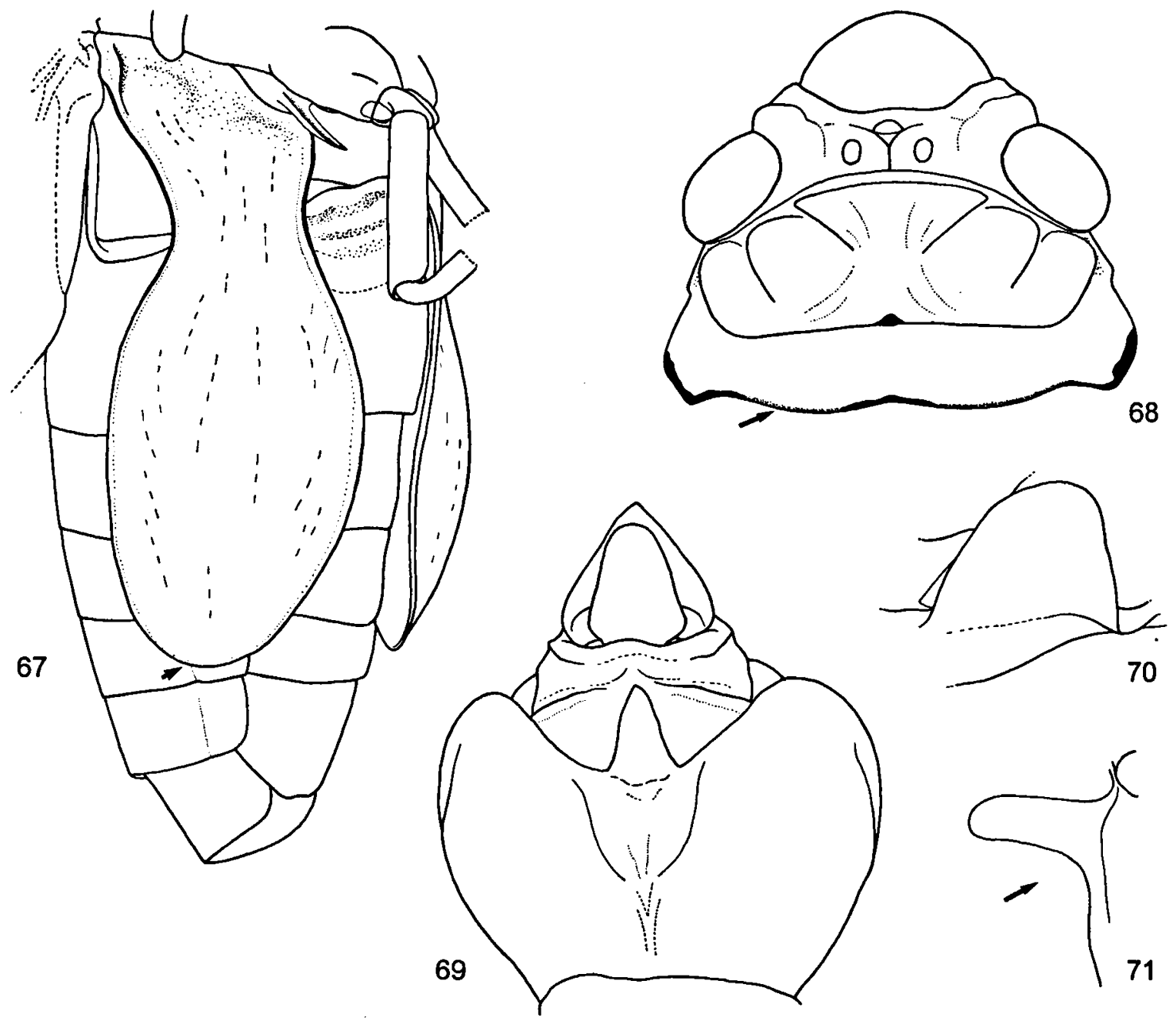

Figs. 67-71. Dundubia ayutthaya n. sp., male, holotype: 67, right operculum in lateroventral view; 68 , head and pronotum in dorsal view; 69, pygofer in dorsal view; 70, right timbal covering; 71, right katepimeral lobe.

operculum, lateral concavity much deeper than medial concavity, broadest part of operculum distal of constriction 1.6-1.9 times as wide as minimum width in constriction. Distance between opercula at constrictions 1.4-1.7 times as wide as minimum width in constriction. Opercula at point of closest approximation separated for a distance of 0.4-0.5 times maximum width between opercula at constrictions. Surface of operculum distal of constriction evenly convex, curved towards abdomen at level of constriction.

Abdomen: Length 1.1-1.2 times as long as head and thorax together. Tergites and sternites ochraceous to ochraceous brown. Tergites 3-7 with brown spots along dorsolateral margin, those on tergites 3-5 almost forming a longitudinal band. Posterior margin of tergite 5 with short spines on medial part; posterior margins of tergites 6 and 7 with longer spines along posterior margin, spines on tergite 7 longer than those on tergite 6 . Timbal covering (Fig. 70) ochraceous, more or less triangular, at base 1.2-1.5 times as wide as long; medioproximal corner sharp; medial margin oblique and slightly convex; mediodistal corner broadly rounded; distal margin slightly convex; laterodistal corner narrowly rounded, lateral margin almost straight. Sternite 7 almost imperceptibly emarginate posteromedially. 
Genitalia (Figs. 65-66, 69): Pygofer and uncus ochraceous to brownish. Basal pygofer lobes well developed, broad and rounded (Fig. 65); hairs on lobes shorter than those on inner ventral margin. Basal part of uncus semicircular, only little globose (Fig. 65) and with numerous erect hairs except on the medial third, laterally placed hairs shorter than medially placed ones. Uncus lobes (Figs. 65-66) at medial and distal margins rounded, medial margins divergent towards mediodistal corners and curved inwards; mediodistal corners rounded; lateral margins as in D. oopaga; bases of uncus lobes with a few erect hairs near lateral margin. Width at laterodistal corners of uncus lobes much less than width at bases.

Female. Operculum ochraceous, reaching from one third to about halfway sternite 3 , curved around abdomen laterally. Lateral margin distal of lateroproximal lobe first convex but more or less straight on distal half; laterodistal corner angular; margin from laterodistal corner to mediodistal corner rounded.

Abdomen: Slightly shorter than head and thorax together. Dorsal part of tergites from ochraceous on tergite 2 to brownish on tergite 7, sternites and ventral parts of tergites ochraceous. Tergites 3-7 with brownish lateral spots, increasing a little in size and intensity from tergite 3 to 7 . Posterior margins of tergites 4-7 with short spines along posterior margins, those on tergite 4 only on lateral part and more slender than on other tergites. Sternite 7 with a rounded posteromedial emargination of variable width.

Genitalia: Pygofer brownish, slightly paler ventrally; distal part of ovipositor sheath brownish. Dorsal margin of pygofer in lateral view concave near base of caudodorsal beak and ventral margin somewhat convex. Ovipositor sheath and anal valve reaching as far as half way to two thirds of apex of caudodorsal beak.

Measurements in $\mathrm{mm}\left(\sigma^{\circ}: \mathrm{n}=7 ; \%: \mathrm{n}=4\right)$. - Body length: $\sigma^{*}$ : 27.5-30.5 (29.2 \pm 0.8$)$, ९: $26.0-28.5(27.3 \pm 1.0)$; head width: o : 8.5-9.0 $(8.8 \pm 0.1)$, \&: $8.7-9.4(9.1 \pm 0.3)$; maximum pronotum width: $\sigma^{\circ}: 9.2-9.8(9.6 \pm 0.1)$, ९ : 9.6-10.5 (10.1 \pm 0.4); tegmen length: $\sigma^{\circ}: 29.5-32.5(31.6 . \pm 0.8)$, $:$ : $31.5-35.0$ $(33.0 \pm 1.5)$.
Etymology. - Ayutthaya is the name of an ancient kingdom that also covered the area in which $D$. ayutthaya now occurs.

Distribution (Fig. 4). - D. ayutthaya has been found at two localities only, both in south-eastern Thailand.

Dundubia spiculata Noualhier, 1896

(Figs. 5, 72-78)

Dundubia spiculata Noualhier, 1896: 254; Noualhier \& Martin, 1904: 178, pl. XI figs. 3-4.

Platylomia spiculata; Distant, 1906b: 61; 1912b: 49; Moulton, 1923: 89; Metcalf, 1963b: 625 .

Dundubia siamensis Haupt, 1918: 82, fig. 1 (n. syn.); Metcalf, 1963a: 534; Overmeer \& Duffels, 1967: 32, 33, 56; Duffels \& Van der Laan, 1985: 118.

Cosmopsaltria hastata Moulton, 1923: 69, 87, 88, 167, figs. 5-5b (partim: Indo-China and Malay Peninsula) (n. syn.); Metcalf, 1963a: 549 (partim: Indo-China and Malay Peninsula).

Orientopsaltria hastata; Duffels, 1983: 9.

Not: Cosmopsaltria hastata; Moulton, 1923: 89 (partim: North Khasi Hills and Assam); Metcalf, 1963a: 549 (partim: Assam) (see D. laterocurvata).

Lectotype designations and synonymy. - $D$. spiculata was described on the basis of four males from Cambodia but no holotype was designated. All four specimens were deposited in the MNP, are in good condition and bear the following two labels: 'Museum Paris / Cambodge / Pavie 1886' [printed] and ' $2872 / 86^{\prime}$ ' handwritten on the reverse side of a round yellow label]. Two specimens bear an additional handwritten label 'Dundubia / spiculata Nlh. / Type B.M.N.H.P. 1896'. The third specimen bears two additional labels 'Dundubia / spiculata / Type Nlh' with 'Bull. Mus. Hist. Nat. / Par. 1896' on the reverse [handwritten] and 'Type répertorié' [printed]. The fourth specimen bears three more labels: 'Cosmopsaltria / spiculata / Nlh.' [handwritten], 'holotype' [printed on red paper], and 'Type répertorié' [printed]. The holotype label and printed labels 'Type répertorié' are apparently of later date than the other labels and are not considered to be a valid lectotype designation. The fourth specimen is here designated as the lectotype and the other three specimens are accordingly labelled as paralectotypes.

D. hastata was described on the basis of material from Thailand and Peninsular Malaysia and the types (one male and one female) were deposited in the BMNH. The male bears the labels 'Type' [printed in red circle], 'Terutau I. / W. Coast Siam' [handwritten], 'Pres. Raffles Mus. / Singapore / Brit. Mus. 1922-302' [printed], 'Cosmopsaltria hastata Moulton / Type o' /m.s. description 19.10.21 J.C.M.' [handwritten]. The female is labelled in the same way except for the fact that it is marked as 
'Type $Q$ ' on the last label and that it bears two handwritten labels ' 15 '. The male is herewith designated as the lectotype and the female as paralectotype. The other material mentioned in the description from the type locality and Tanjong Hantu in Peninsular Malaysia and supposedly deposited in the Federal Malay States Museum (FMS; Kuala Lumpur) and Raffles Museum (Singapore) could not be examined. It should be noted, however, that in 1955 the whole entomological collection of the FMS was transferred to the BMNH. Nevertheless, the other specimens supposedly in the FMS collection were not found in the BMNH. According to Moulton (1923: 89) D. hastata 'is perhaps most similar to Platylomia spiculata Noualhier which has similarly "spear-head" but narrower opercula.' Since this character of the opercula shows a considerable amount of variation and no differences could be found in the genitalia of $D$. spiculata and D. hastata these species are considered to be synonymous.

D. siamensis was described on the basis of one male from northern Thailand. According to the description it was deposited in the NLHD. However, it could not be located in that collection and is presumed to be lost (see Overmeer \& Duffels, 1967). The description and illustration given by Haupt (1918) are clear enough to place $D$. siamensis close to $D$. spiculata. Since no other related species with acutely pointed opercula is known besides $D$. spiculata, it is assumed that $D$. spiculata and D. siamensis are synonymous.

Material examined. - Vietnam: Baria [Ba Ria], Cochin Chine, 1910, Vauthier, 1 o*, MNP; Blao [Balao or Bao Loc], $500 \mathrm{~m}$, 14-21.x.1960, C.M. Yashimoto, 3 o o , BPBM; same data, 2 o* ơ, ZMA; Di Linh, 27.ix-14.x.1960, C.M. Yashimoto, 4 ○ $\sigma^{\circ}, \mathrm{BPBM}$; same data, 2 o $\sigma^{\circ}, \mathrm{ZMA}$; same data, 27.ix14.x.1960, light trap, 3 o $\sigma^{\circ}$, BPBM; $17 \mathrm{~km} \mathrm{S.} \mathrm{of} \mathrm{Di} \mathrm{Linh,} 1300$ m, 6-13.x.1960, C.M. Yashimoto, 1 o, 1 \&, BPBM; Sang-Bé [Song Be], 1878, Harmand, 1051 78, 1 \%, 1 \%, MNP.

Cambodia: Cambodge, 1885, A. Pavie, $1 \sigma^{\circ}$, BMNH; Cambodge, 1886, Pavie, 2872 86, $\sigma^{\circ}$ lectotype and 3 o $\sigma^{\circ}$ paralectotypes Dundubia spiculata, MNP.

Laos: Ban Van Eue, Vientiane Province, 1965, native collector, 1 o*, BPBM; same data, 30.ii.1965, 1 \% , BPBM; same data, 30.xi.1965, J.L. Gressitt, Malaise trap, 1 ơ, BPBM; same data, 15.iii.1966, native collector, 1 \&, BPBM; same data, 16.iii.1966, J. Rondon, 1 \&, BPBM; same data, 15.viii.1966, native collector, 19 ơ $\sigma$, BPBM; same data, 15.viii.1966, native collector, $2 \sigma^{\circ} \sigma^{*}, \mathrm{ZMA}$; Laos, 1884, Neis, $1 \sigma^{\circ}, \mathrm{BMNH}$; Luang Prabang, ix.1917, R.V. de Salvaza, $1 \sigma^{\circ}$, BMNH; Muong Va [Muang Va], 4.xi.1918, R.V. de Salvaza, $1 \sigma^{\circ}$, BMNH; Pak Hang [Pakhang], Khane R. [river Khan], 28.ix.1918, R.V. de Salvaza, $1 \sigma^{\circ}$, BMNH; Pak Neun [Ban Pakneun], Luang Prabang, 28.ix.1918, R.V. de Salvaza, 1 o , BMNH; same data, 1.x.1918, 4 ơ O', BMNH; Sayaboury, Sayaboury Province, 6.xii.1965, native collector, $1 \sigma^{\circ}$, BPBM; same data, 15.ix. 1966, 5 ơ ơ, BPBM; same data, 15.ix.1966, 2 ơ ơ, ZMA; same data, xi.1966, 1 \% , BPBM; same data, 12.xi.1966, 2 o $\sigma^{\circ}$, BPBM; same data, 13.xii.1966, 6 ơ ơ, BPBM; Thadeua [Muang Thadua], 2.x.1918, R.V. de Salvaza, $3 \sigma^{\circ} \sigma^{\circ}, \mathrm{BMNH}$.

Burma: Moulmein, Lr [Lower] Burma, Hood, $1 \sigma^{\circ}, \mathrm{BMNH}$. Thailand: Ban-tin-doi, Chiengmai [Chiang Mai], $310 \mathrm{~m}$, 13.xi.1957, J.L. Gressitt, Malaise trap, $1 \sigma^{\circ}$, BPBM; same data, 1000 ft, H.G. Deignan, $1 \sigma^{\circ}$, USNM; Doi Musae, $1 \propto \sigma, 1$, RMNH; Doi Suthep, North Thailand, ix.1958, B. Degerbøl, Pr. 1314 (1.7.59), $1 \sigma^{\circ}$, UZMK; Doi Suthep, Chiang Mai, Northern Thailand, $1100 \mathrm{~m}, 11 . i x .1988$, M.G. Allen, 1 \% , SEM; same data, 2 ơ $\sigma^{\circ}$ : ZMA; Horticultural Experimental Station, 7 km north-west of Fang, 30.x-2.xi.1979, Expedition Zoological Museum Copenhagen, 1 \%, UZMK; Phu Luang Wildlife Sanctuary, Loei Province, 1400-1500 m, 10-12.x.1984, Karsholt, Lomholdt \& Nielsen, 1 o, UZMK; Payao [Phayao] 8-31-5190, D. \& E. Thurman, $1 \sigma^{*}$, USNM; Siam, W.R.S. Ladell, 2 O॰ ơ, BMNH; Terutau I. [Ko Tarutao], W. coast of Siam, ơ lectotype and $1 \%$ paralectotype Cosmopsaltria hastata Moulton, BMNH; Thale Ban National Park, Satun province, $6^{\circ} 42^{\prime} \mathrm{N}$ $100^{\circ} 10^{\prime}$ E, 22-24.x.1991, O. Martin, 1 \&, UZMK.

Peninsular Malaysia: Hutan Wong Kelian, Perlis, 1520.x.1990, Zaidi \& Ruslan, 1 \% , UKMS.

Exact location unknown: $1 \sigma^{\circ}, \mathrm{BMNH}$; Indes Orientales, Mniszech, 110 59, 1 \% , MNP; Indochina, R. Vitalis, $1 \sigma^{\circ}$, BMNH.

Remarks. - D. spiculata is an ochraceous to greenish species of which only the posterior margin of the pronotal collar is black and the paramedian fasciae on the mesonotum are dark brown or black. The most striking character is the shape of the male operculum which is pointed at the apex (Fig. 74). In the male genitalia the uncus lobes are rounded distally and shallowly emarginate laterally, the basal pygofer lobes are little swollen and hardly developed (Fig. 72).

Description. - Body greenish to ochraceous, paramedian fasciae on mesonotum dark. Fresh and well-prepared specimens are probably green rather than ochraceous.

Head (Fig. 75): Postclypeus unicolorous ochraceous. Anteclypeus brownish laterally, shape of markings variable. Vertex ochraceous or slightly greenish, anterior ocellus sometimes with narrow dark border and frontoclypeal suture darkened. Head otherwise ochraceous to ochraceous brown. Suture between vertex lobe and supra-antennal plate consisting of a small rounded depression near anterior margins of plates, depression only seldom merging with the longitudinal groove running along lateral part of frontoclypeal suture and between eye and lateral ocellus. Frontoclypeal suture semicircular but almost straight medially. Rostrum ochraceous but darkened at apex, just reaching between bases of posterior coxae. 

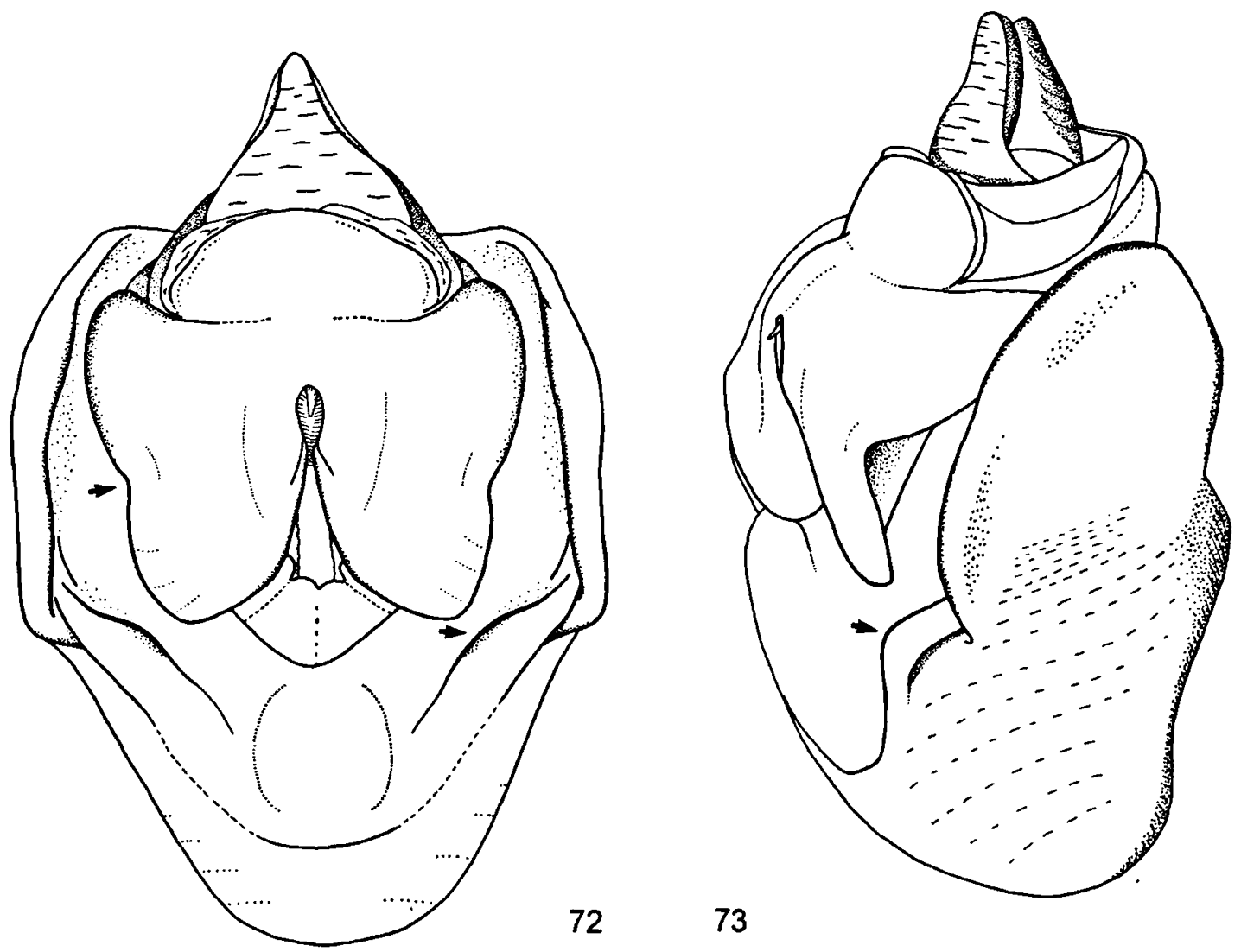

Figs. 72-73. Dundubia spiculata Noualhier, 1896, male, Doi Suthep: 72, pygofer and uncus in ventral view; 73, pygofer and uncus in lateroventral view.

Thorax: Pronotum distinctly broader than head (Fig. 75). Pronotal disc ochraceous, often narrowly to broadly greenish medially; medial spot immediately in front of pronotal collar distinct (Fig. 75). Pronotal collar ochraceous or extensively greenish, especially on posterior part, no lateral spots present (Fig. 75); anterior margin with some very short, thick, dark spiny bristles, tooth on lateral margin sometimes reduced and margin there almost rounded (Fig. 75), posterior corner smoothly rounded. Mesonotum ochraceous or light brown, paramedian fasciae narrow, blackish or dark brown, pairs of brown spots may be present in front of lateral arms of cruciform elevation and on posterolateral corners of mesonotal disc. Katepimeral lobe (Fig. 78) about as long as basal width, little narrowed on basal half and more or less triangular; dorsal margin weakly convex; apex almost angularly rounded; ventral margin concave on basal half and somewhat convex on apical half. Surface of katepimeral lobe rather strongly concave on dorsal half and densely covered with short hairs and waxy coating, hairs on margins about twice as long and interspersed with many even longer hairs. Apex of katepimeral lobe just not reaching base of operculum or extending just over base.

Tegmina and wings: Tegmina hyaline but sometimes somewhat brownish distally and with indistinct brownish reticulation between veins in distal part; basal cell infuscate. Veins of tegmen ochraceous brown, darker posteriorly. Wings hyaline; veins ochraceous brown to brown.

Legs: Fore legs largely ochraceous; femora with darkened posteroventral stripe just dorsal of femoral spines; tibiae somewhat darkened apically and 

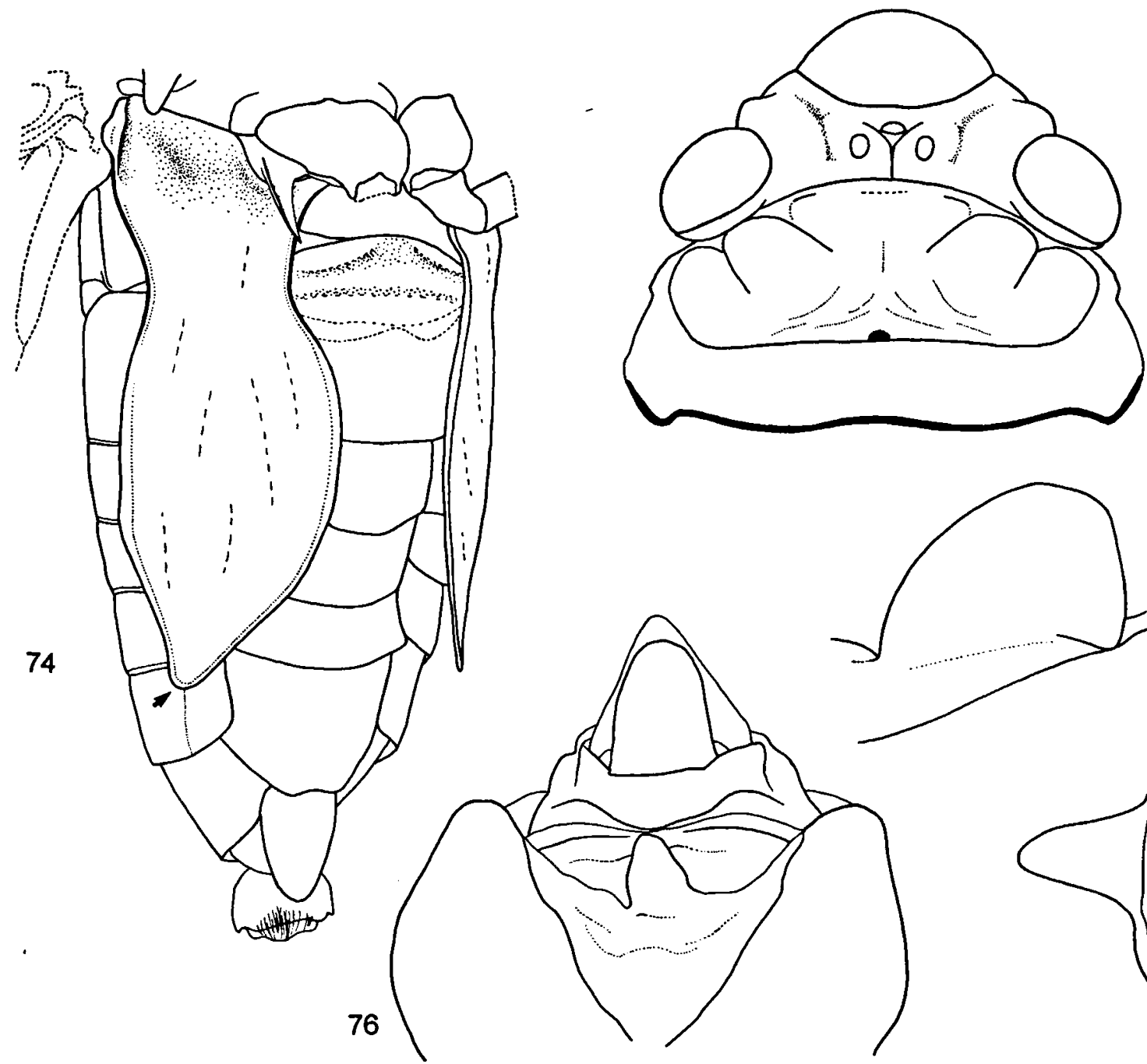

Figs. 74-78. Dundubia spiculata Noualhier, 1896, male: 74, right operculum in lateroventral view, Doi Suthep; 75 , head and pronotum in dorsal view, Doi Suthep; 76, pygofer in dorsal view, Indes Orientales; 77, right timbal covering, Doi Suthep; 78, right katepimeral lobe, Doi Suthep.

often also ventrally; tarsi brownish. Mid legs ochraceous; tibiae darker apically and sometimes also ventrally; tarsi brownish. Hind legs ochraceous to greenish; tibiae little darkened near apex and tibial spines brownish with dark apex; tarsi little darkened. Fore femur with middle spine shorter than proximal spine and pointed; distal spine very small and somewhat pointed; gap between middle and distal spines rather deep.

Male. Operculum (Fig. 74): Long, reaching from just beyond anterior margin of sixth abdominal segment to just beyond anterior margin of seventh abdominal segment, 2.4-2.8 times as long as maximum width distal of constriction; largely ochraceous but greenish to varying extent. Medial margin concave near base, smoothly convex distal of constriction but slightly straightening close to apex. Apex bluntly pointed, almost in line with lateral margin. Lateral margin concave at level of timbal covering and a short distance beyond, distal of constriction only weakly convex and near apex 
often even somewhat concave, thus often increasing impression of apex being pointed. Constriction at 0.3-0.4 of length of operculum, medial concavity slightly less deep than lateral concavity, broadest part of operculum distal of constriction 1.5-1.6 times as wide as minimum width in constriction. Distance between opercula at constrictions 1.4-1.6 times as wide as minimum width in constriction. Opercula at point of closest approximation separated for a distance of (0.3) 0.5-0.6 times maximum width between opercula constrictions. Surface of operculum distal of constriction almost entirely flat, curved around abdomen at lateral margin, hardly convex in longitudinal direction.

Abdomen: Length 1.1-1.2 times that of head and thorax together. Tergites and sternites ochraceous to ochraceous brown, anterior segments lighter ventrally, posterior segments sometimes darker. Tergites 3-7 with dark spots along lateral margin. Posterior margin of tergite 6 with short dark spines laterally, posterior margin of tergite 7 with spines along whole length. Timbal covering (Fig. 77) ochraceous, at base 1.5 times as wide as long; medial margin curved sideways; distal margin convex; laterodistal corner smoothly rounded; lateral margin slightly convex. Sternite 7 shallowly emarginate posteromedially.

Genitalia (Figs. 72-73, 76): Pygofer and uncus ochraceous to ochraceous brown. Basal pygofer lobes slightly angular (Fig. 72) to almost completely reduced. Basal part of uncus semicircular and globose (Fig. 72) and with some thick erect hairs on anterior surface and some long pale hairs near bases of uncus lobes. Uncus lobes (Figs. 7273) at medial and distal margins rounded, medial margin curved inwards; lateral margins emarginate, laterodistal corners rounded; bases of uncus lobes with some thick erect hairs. Width at laterodistal corners of uncus lobes slightly less than width at bases.

Female. Operculum ochraceous and not reaching beyond halfway sternite 3 , curved around abdomen laterally. Lateral margin distal of lateroproximal lobe convex; laterodistal corner angularly rounded; posterior margin almost straight; mediodistal corner broadly rounded, medial margin short.
Abdomen: Length 0.9-1.0 times that of head and thorax together. Dorsal part of tergites ochraceous, sternites and ventral parts of tergites paler. Tergites 4-7 with darker lateral spots less distinct than in male. Posterior margins of tergites 4 and 5 with few very short dark spines laterally; posterior margins of tergites 6 and 7 with spines along whole length, those on tergite 7 longer; posterior margin of tergite 8 with scattered spines medially. Sternite 7 with almost triangular posteromedial emargination.

Genitalia: Very similar to those of $D$. oopaga in structure. Dorsal part of pygofer almost brownish, ventral part ochraceous; distal part of ovipositor sheath brownish. Dorsal margin of pygofer in lateral view slightly concave, ventral margin somewhat convex. Ovipositor sheath not or just reaching as far as apex of caudodorsal beak, anal valve only slightly shorter.

Measurements in $\mathrm{mm}\left(\sigma^{\prime}: \mathrm{n}=7 ; q: \mathrm{n}=5\right)$. - Body length: $\sigma^{\prime \prime}$ : 33.0-36.5 (35.1 \pm 1.1$)$, ᄋ : 32.0-38.0 (33.6 \pm 1.9$)$; head width: o: : 10.7-11.6(11.3 \pm 0.3$)$, o : 10.5-13.0(11.4 \pm 0.6$)$; maximum pronotum width: $\sigma^{\prime}: 11.8-13.0(12.5 \pm 0.4)$, $९$ : $12.3-14.3$ (12.8 \pm 0.6 ); tegmen length: $\sigma^{\prime \prime}: 41.0-43.0(42.2 \pm 0.8)$, ९ : 40.5-47.0 $(42.6 \pm 1.9)$.

Distribution (Fig. 5). - D. spiculata is widespread in Indo-China (Burma, Cambodia, Laos, Thailand, and Vietnam) and is also found on the Malay Peninsula.

Some of the old records in the literature may be unreliable because of the close resemblance between $D$. spiculata, D. laterocurvata, and D. sinbyudaw. The records of $D$. hastata from India (Moulton, 1923) probably refer to D. laterocurvata. The record from the Malay Archipelago (Metcalf, 1963a) is a misinterpretation of data in Moulton (1923).

\section{Dundubia laterocurvata $\mathrm{n}$. sp.}

(Figs. 5, 79-85)

Dundubia mannifera (nec Walker) var. a; Distant, 1889: 39 (partim: North Khasi Hills); 1892b: xi (partim: India).

Cosmopsaltria hastata Moulton, 1923: 69, 87, 88, 167 (partim: North Khasi Hills and Assam); Metcalf, 1963a: 549 (partim: Assam). 

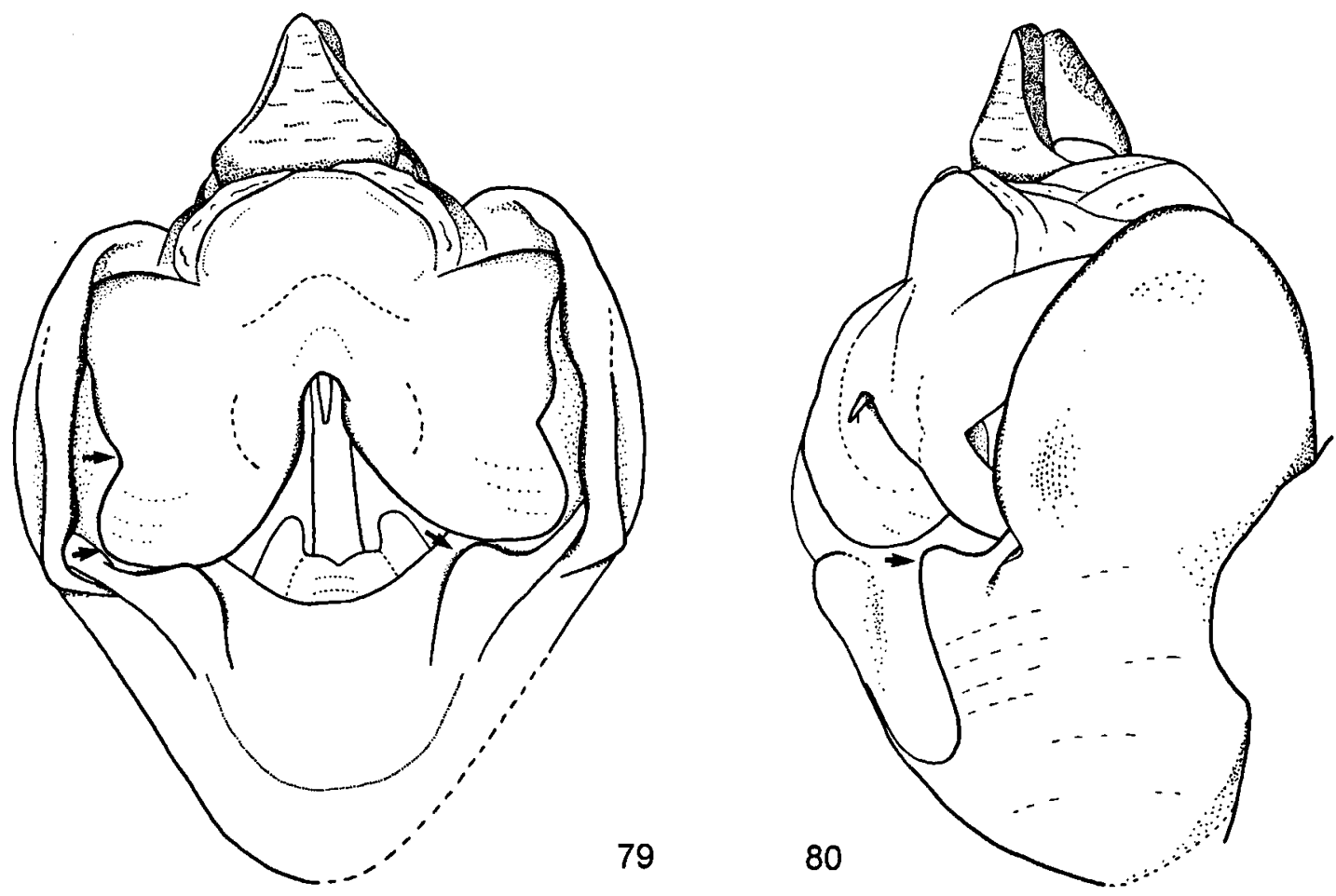

Figs. 79-80. Dundubia laterocurvata n. sp., male, paratype Mogauag: 79, pygofer and uncus in ventral view; 80 , pygofer and uncus in lateroventral view.

Material examined. - Holotype: 'Mogauag / Burma ix.15.1944 / Cpt. L.C. Kuitert, ơ, SEM. Paratypes: Burma: Mogauag [typographical error for Mogaung], 15.ix.1944, L.C. Kuitert, 6 O’ ơ, SEM; same data, 3 ơ ơ, ZMA; Myitkyina, 10.ix.1944, G.W. Miller, 1 o , SEM; Myitkyina, 10.x.1944, L.C. Kuitert, 2 ơ ơ, SEM; India: Assam, 2 ơ ơ, BMNH; same data, $1 \sigma^{\circ}$, ZMA; Darjiling District, c $2000 \mathrm{ft}$, 'rains' 1912, Bemet, 1 o', BMNH; Dilkoosha, Assam, 1 \%, BMNH; Nazeerah [Nazira], Assam, Foster, 1 \% , BMNH; North India, 1 o , BMNH; North Khasia [Khasi Hills], 1 o', ZMA; Sikkim, E. Himalayas, Knyvett, 1 \&, BMNH; Sonapur, Assam, L.W. Middleton, 1 o', ZMA.

Other material examined. - India: Sikkim, iii-iv, H. Fruhstorfer, 2 \% \%, NHMW.

Exact location unknown: India Orientalis, [Fry?], $1 \sigma^{\circ}, 1$ \&, BMNH.

Remarks. - D. laterocurvata very much resembles D. spiculata in size and general appearance. In the male genitalia the uncus lobes are bent sideways and their medial margins are divergent (Fig. 79). The basal lobes of the pygofer are projecting and rounded (Fig. 79). This species can be most easily separated from $D$. spiculata by the shape of the male operculum (Fig. 81), which is always broad and angularly rounded instead of pointed at the apex.

Description. - Body ochraceous, often tinged green, especially pronotal collar and opercula. Fresh and well-prepared specimens are probably green rather than ochraceous.

Head (Fig. 82): As in D. spiculata but anteclypeus less darkened laterally. Frontoclypeal suture trapezoid. Suture between vertex lobe and supra-antennal plate consisting of small rounded depression near anterior margins of plates, depression usually being connected by shallow groove with longitudinal groove running along lateral part of frontoclypeal suture and between eye and lateral ocellus.

Thorax: Pronotum distinctly broader than head (Fig. 82). Pronotal disc and pronotal collar (Fig. 82 ) as in D. spiculata, anterior margin of pronotal collar with numerous short spiny bristles. Mesonotum as in D. spiculata. Katepimeral lobe (Fig. 85 ) about as long as basal width and generally 


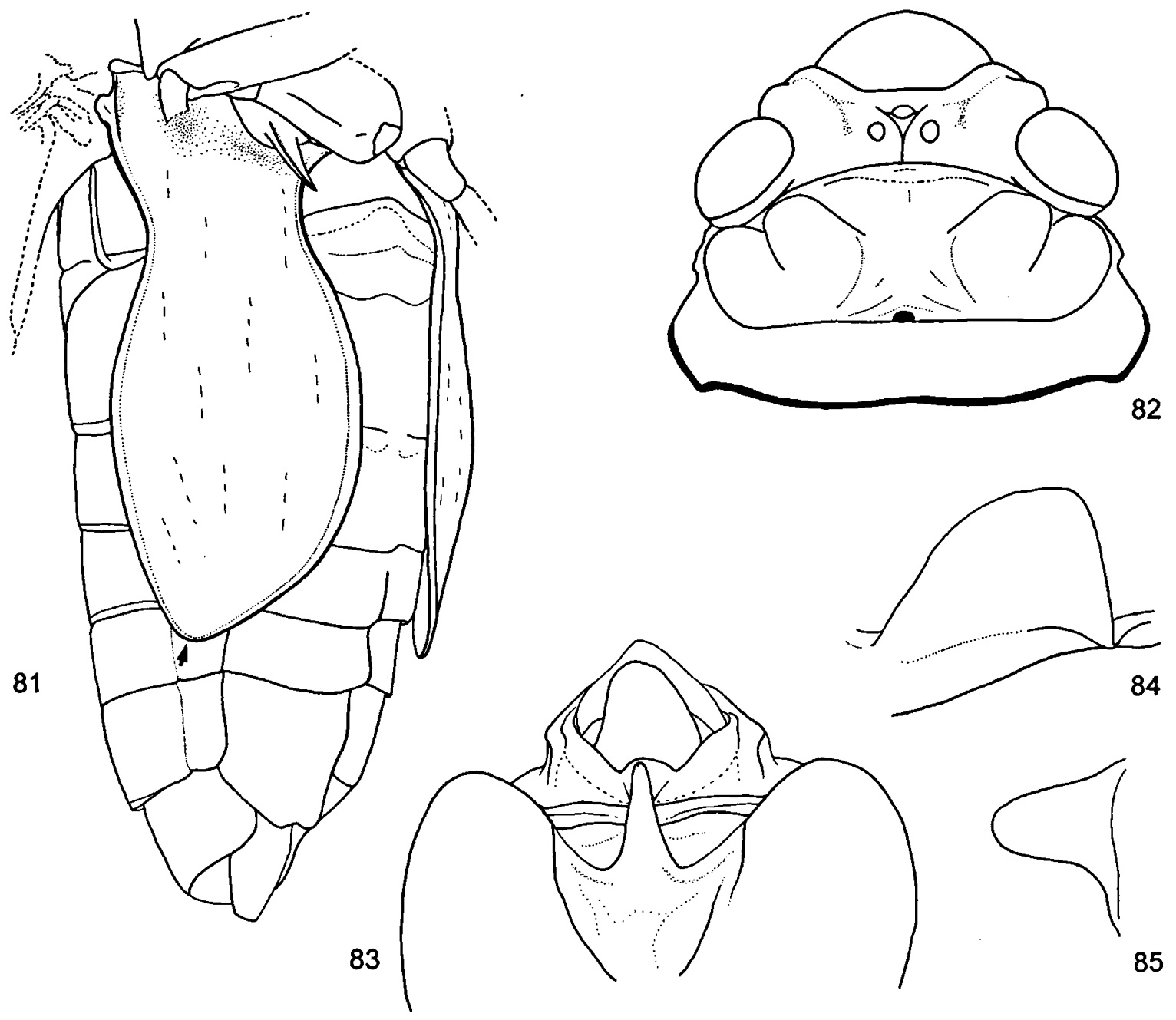

Figs. 81-85. Dundubia laterocurvata n. sp., male: 81, right operculum in lateroventral view, paratype Mogauag; 82, head and pronotum in dorsal view, paratype Mogauag; 83 , pygofer in dorsal view, paratype North India; 84 , right timbal covering, paratype Mogauag; 85, right katepimeral lobe, paratype Mogauag.

broad; dorsal margin weakly convex although sometimes weakly concave near base; apex rounded, often slightly angularly rounded; ventral margin concave on basal half and straight to somewhat convex on apical half. Surface of katepimeral lobe weakly concave on dorsal half and densely covered with short hairs and waxy coating, hairs on margins about twice as long but even longer near base. Apex of katepimeral lobe just extending over base of operculum.

Tegmina and wings: Tegmina hyaline, as in $D$. spiculata but without any trace of infuscation at basal veins of second and third apical cells. Veins of tegmen brown. Wings hyaline; veins brown.

Legs: Ochraceous to brownish, pattern of darkening as in D. spiculata but somewhat weaker. Fore femur with middle spine pointed, shorter than proximal spine; distal spine very small and blunt; gap between middle and distal spines shallow.

Male. Operculum (Fig. 81): Long, almost reaching middle of sixth to almost base of seventh abdominal segment, 2.1-2.3 times as long as maximum width distal of constriction; ochraceous to brown, often extensively greenish. Medial and lateral margins as in $D$. spiculata but convex parts more 
strongly convex and operculum broader. Apex angular but not pointed, almost in line with lateral margin. Constriction at 0.3-0.4 of length of operculum, broadest part of operculum distal of constriction 1.5-1.8 times as wide as minimum width in constriction. Distance between opercula at constrictions 1.3-1.6 times as wide as minimum width in constriction. Opercula at point of closest approximation separated for a distance of 0.4-0.6 times maximum width between opercula at constrictions. Surface of apical part of operculum only weakly convex, most distinct near lateral margin, lateral margin of opercula close to abdomen.

Abdomen: About 1.1 times as long as head and thorax together. Tergites and sternites ochraceous to castaneous brown, anterior segments lighter ventrally. Markings and spines along posterior margins of tergites as in D. spiculata. Timbal covering (Fig. 84) as in D. spiculata but medial margin longer. Sternite 7 emarginate posteromedially, with a sinuous transverse groove at two thirds from its base, often darkened near transverse groove and on posterior margin.

Genitalia (Figs. 79-80, 83): Colour as in $D$. spiculata. Basal pygofer lobes pronounced, swollen and rounded (Figs. 79-80). Basal part of uncus as in D. spiculata. Uncus lobes (Fig. 79) large and turned sideways, medial margin curved inwards; bases of uncus lobes with some thick erect hairs. Width at laterodistal corners of uncus lobes about equal to or greater than width at bases.

Female. Operculum ochraceous brown, reaching from base to about one third of third abdominal segment, curved around abdomen laterally. Lateral margin distal of lateroproximal lobe straight with rounded bend about halfway; laterodistal corner angularly rounded; distal margin slightly convex; mediodistal corner broadly rounded.

Abdomen: Length 0.8-0.9 times that of head and thorax together. Dorsal part of tergites brown, sternites and ventral parts of tergites only little lighter. Tergites 4-7 with brownish lateral spots. Posterior margins of tergite 4 and 5 with few scattered spine-like setae laterally, spines more numerous on tergite 5 , posterior margin of tergite 6 with scattered short dark spines that are almost wanting medially, posterior margin of tergite 7 with spines along whole length; posterior margin of tergite 8 with scattered spines medially. Sternite 7 with rounded posteromedial emargination.

Genitalia: Pygofer ochraceous brown, slightly darker dorsally; distal part of ovipositor sheath castaneous. Dorsal margin of pygofer in lateral view slightly concave, ventral margin weakly convex. Ovipositor sheath reaching about as far as caudodorsal beak or slightly shorter; anal valve not reaching as far as ovipositor sheath and caudodorsal beak.

Measurements in mm ( $\$: \mathrm{n}=2)$. - Body length: $O$ : $35.0-38.0$ $(36.8 \pm 1.0)(n=5), ~ \&: 34.0-34.5(34.3 \pm 0.3)$; head width: $\sigma^{*}:$ 11.0-11.8 (11.5 \pm 0.3$)(n=5), ~ \&: 11.7-12.1(11.9 \pm 0.2)$; maximum pronotum width: $\sigma^{\circ}: 12.1-13.2(12.8 \pm 0.4)(n=5)$, ᄋ : 13.5-13.6 (13.6 \pm 0.1$)$; tegmen length: $\sigma$ : 42.0-45.5 (44.4 \pm 1.2) $(n=4)$, $Q: 44.5-45.0(44.7 \pm 0.3)$.

Etymology. - The name of this species is derived from the specific shape of the uncus lobes which are bent sideways.

Distribution (Fig. 5). - D. laterocurvata has the most northerly distribution of the species in the $D$. jacoona assemblage. It has been found in northern India and northern Burma. It seems very likely that Indian (and Bengalese) records of $D$. vaginata [also as $D$. mannifera (Linnaeus, 1754) and $D$. mannifera var. terpsichore; see references in Metcalf, 1963a] all belong to this species, although it could be possible that more eastern records (close to Burma) refer to $D$. sinbyudaw.

\section{Dundubia sinbyudaw n. sp.}

(Figs. 5, 86-91)

Material examined. - Holotype: 'Myitkyina Burma / III.10.1945 / L. C. Kuitert', ơ, SEM. Paratypes: Thailand: Khow Sai Dow [Khao Soi Dao], Trong, Lower Siam, $1000 \mathrm{ft}$, W.L. Abbott, $10^{\circ}$, USNM; same data, $1 \sigma^{\circ}$, ZMA; Khao Sabap [Khao Sa Bap], Chantaboon [Chantaburi], 1936, J. Macbeth, 1 ơ, ZMA; Khao Yai National Park, 1200 m, 7.ii.1986, M.G. Allen, $2 \sigma^{\circ} 0^{\circ}, \mathrm{BMNH}$; same data, 6.ii.1988, $10^{\circ}$, ZMA; Lomlo Mt. [Phu Lom Lo], 15.xi.1955, R.E. Elbel, $2 \sigma^{\circ} \sigma^{\circ}$, USNM; Nan, 27.i.1928, T.D.A. Cockerell, 1 ơ, USNM; same data, 29.i. 1928, 1 o, USNM; Burma: Myitkyina, 10.iii.1945, L.C. Kuitert, $2 \sigma^{\circ} \sigma$, SEM; Laos: Ban Nahan, French Laos, J.F. Godfrey, 1 \%, BMNH; Hoi Kun Yuang, French Laos, J.F. Godfrey, $1 \sigma^{\circ}$, BMNH; Na Toong, French Laos, J.F. Godfrey, 

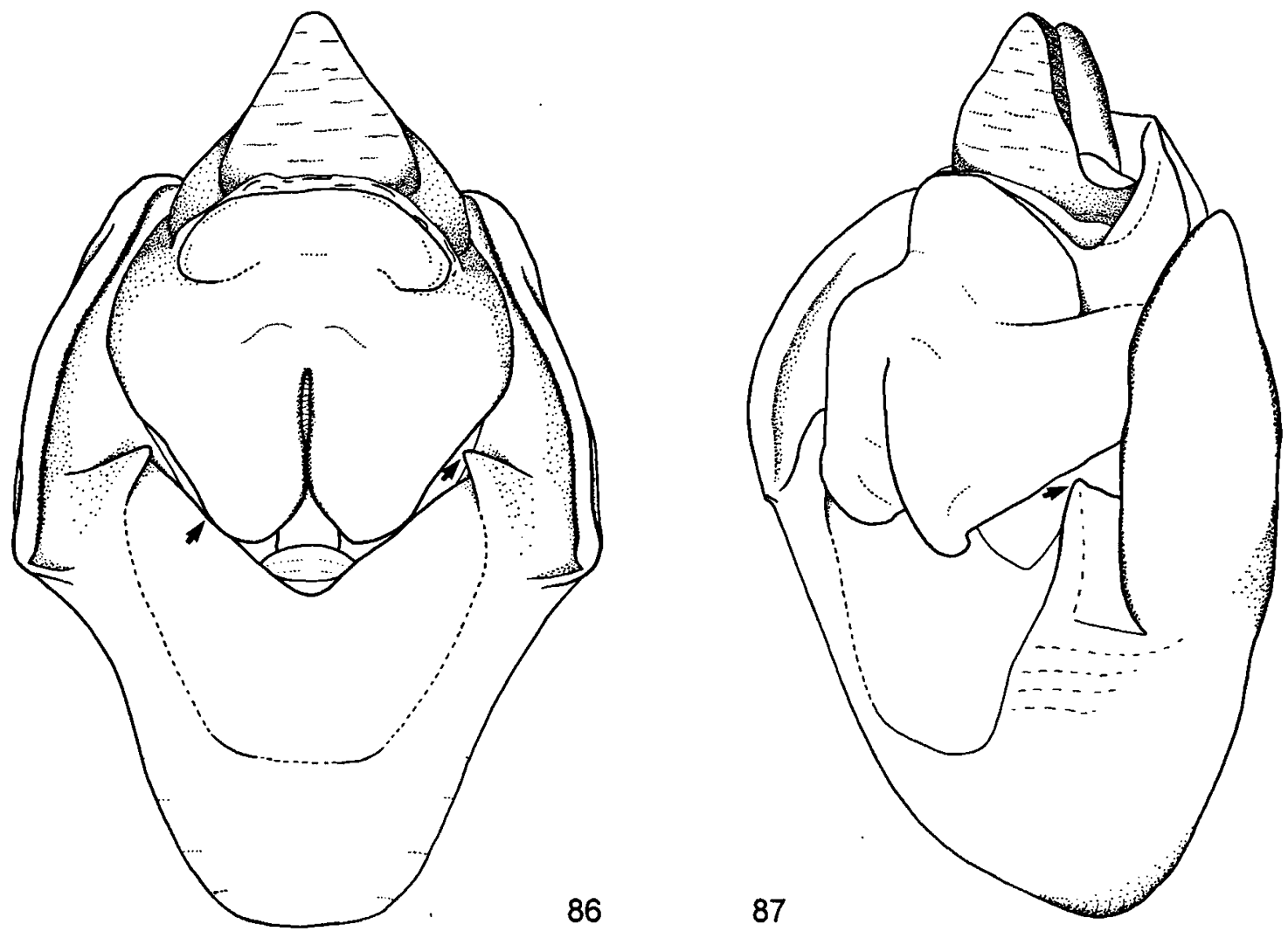

Figs. 86-87. Dundubia sinbyudaw n. sp., male, paratype Myitkyina: 86, pygofer and uncus in ventral view; 87 , pygofer and uncus in lateroventral view.

$1 \sigma^{\circ}$, BMNH; Vientiane, Vientiane Province, 11.ii.1966, native collector, 1 o , BPBM.

Other material examined. - No locality given: $1 \sigma^{\circ}, 1$ \% [with identical acquisition number], BMNH.

Remarks. $-D$. sinbyudaw very much resembles $D$. spiculata in size and general appearance. The uncus lobes are narrowed towards the rounded apex (Fig. 86). The basal pygofer lobes are pointed (Figs. 86-87). The basal lobes of the pygofer are projecting and rounded. This species can be most easily separated from $D$. spiculata by the shape of the operculum (Fig. 88), which is broader and rounded at the apex. The description of the female is based on a single specimen of uncertain origin that was associated with a male bearing the same labels.

Description. - Body ochraceous, often tinged green, especially pronotal collar and opercula.
Fresh and well-prepared specimens are probably green rather than ochraceous.

Head: Postclypeus ochraceous, anterodorsally somewhat darker. Anteclypeus unicolorous ochraceous to greenish. Vertex ochraceous, vertex lobes and supra-antennal plates somewhat darker anteriorly. Head otherwise ochraceous. Vertex lobes narrow. Suture between vertex lobe and supraantennal plate consisting of a narrow groove that merges with longitudinal groove running along lateral part of frontoclypeal suture and between eye and lateral ocellus. Frontoclypeal suture semicircular, but slightly angular between medial and lateral parts, medial part as wide as distance between medial margins of lateral ocelli.

Thorax: Pronotum distinctly broader than head. Pronotal disc and pronotal collar as in D. spiculata, but medial spot immediately in front of pronotal collar indistinct or absent. Short spiny bristles on anterior margin apparently absent. Mesono- 


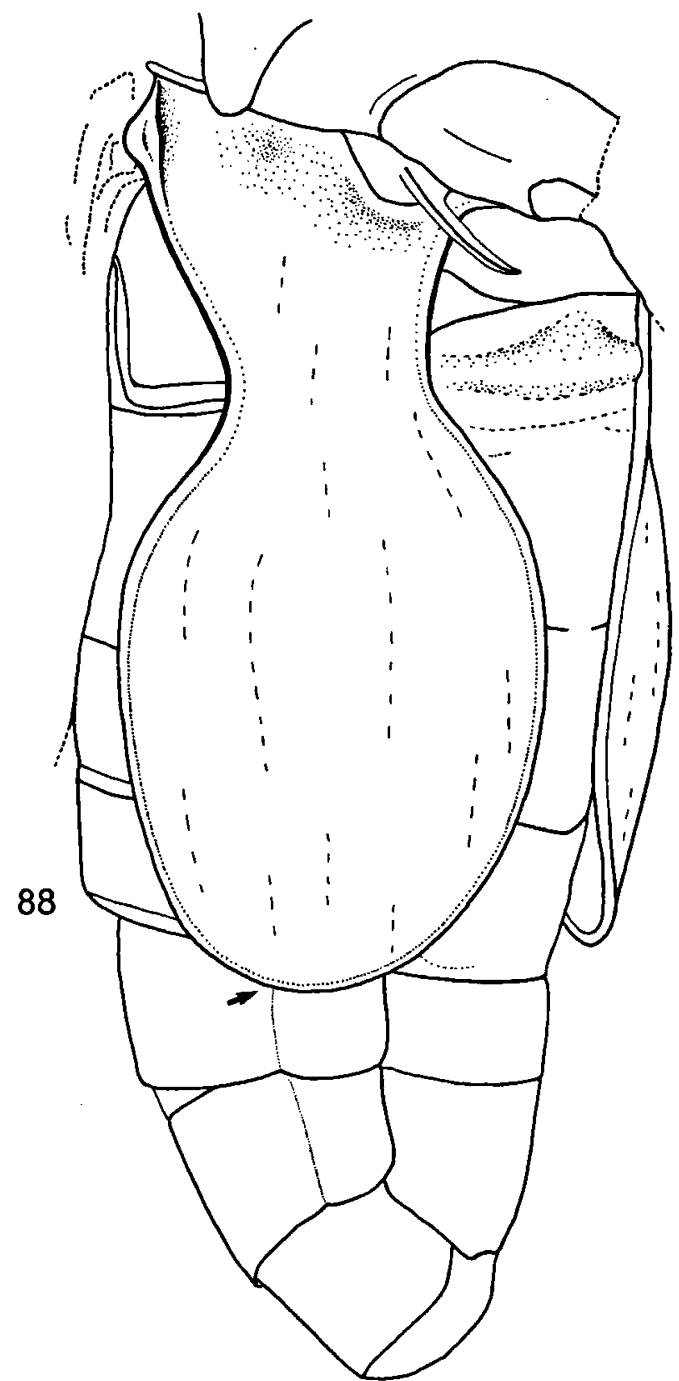

tum ochraceous, paramedian fasciae narrow and brownish to vestigial, occasionally anterior margin with small brownish marks lateral of paramedian fissures. Katepimeral lobe (Fig. 91) shorter than or as long as basal width and not very broad; dorsal margin almost straight; apex rounded; ventral margin concave on basal half and straight to somewhat convex on apical half. Surface of katepimeral lobe weakly concave on dorsal half and densely covered with short hairs and waxy coating and with many long hairs near margins. Apex of katepimeral lobe just extending over base of operculum.

Tegmina and wings: Tegmina hyaline, often with indistinct brownish reticulation between veins in distal part; basal cell infuscate; veins
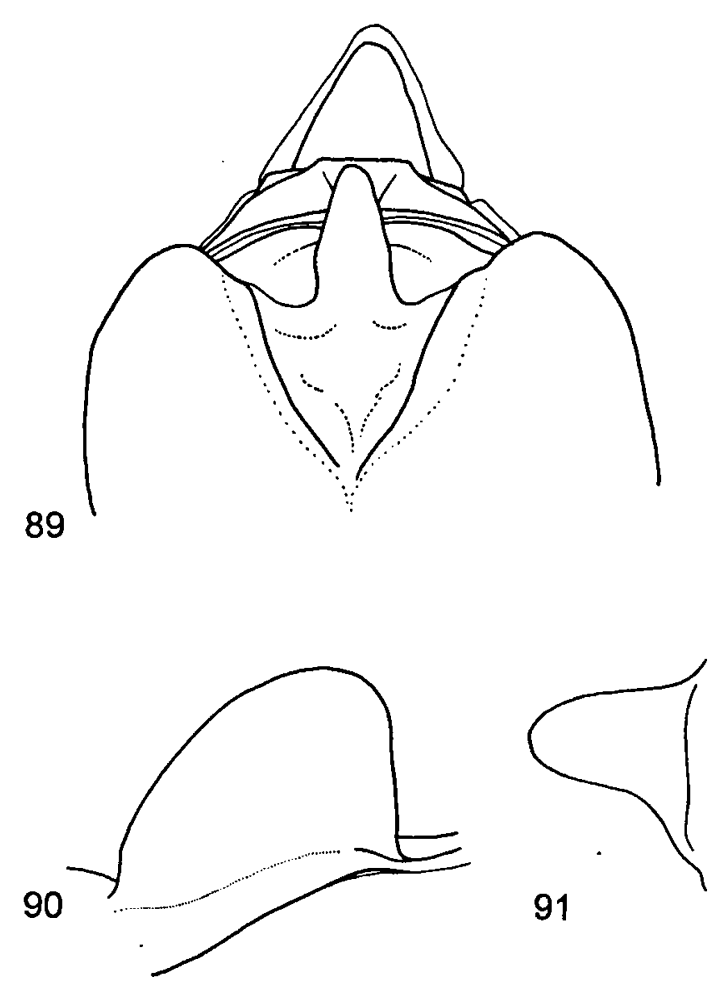

91

Figs. 88-91. Dundubia sinbyudaw n. sp., male: 88, right operculum in lateroventral view, paratype Myitkyina; 89 , pygofer in dorsal view, paratype Nan; 90 , right timbal covering, paratype Myitkyina; 91, right katepimeral lobe, paratype Myitkyina.

ochraceous but slightly darker distally and posteriorly. Wings hyaline; veins ochraceous but slightly darker distally and posteriorly.

Legs: Ochraceous to ochraceous brown, only tarsi somewhat darkened. Fore femur with middle spine smaller and more blunt than proximal spine; distal spine very small and blunt or absent, if present gap between middle and distal spines shallow.

Male. Operculum (Fig. 88): Long, reaching from just beyond anterior margin of sixth to halfway seventh abdominal segment, 2.0-2.3 times as long as maximum width distal of constriction; ochraceous but extensively greenish near apex. Medial 
margin concave near base, smoothly convex from about one third of its length to apex. Apex broadly rounded, extreme tip on or somewhat lateral of longitudinal midline of operculum. Lateral margin concave at level of timbal covering and a short distance beyond, smoothly convex distal of constriction. Constriction at $0.3-0.4$ of length of operculum, medial concavity slightly less deep than lateral concavity, broadest part of operculum distal of constriction 1.8-2.1 times as wide as minimum width in constriction. Distance between opercula at constrictions 1.6-1.7 times as wide as minimum width in constriction. Opercula at point of closest approximation separated for a distance of about 0.3 times maximum width between opercula at constrictions. Surface of operculum distal of constriction practically following outline of abdomen, only weakly convex longitudinally, curved around abdomen at lateral margin.

Abdomen: Length 1.1-1.2 times that of head and thorax together. Dorsal part of tergites ochraceous to ochraceous brown, darkened along a narrow median line on anterior tergites; sternites and ventral parts of tergites ochraceous to ochraceous brown, anterior and posterior segments lighter ventrally. Tergites as in $D$. spiculata but lateral spots less distinct, posterior margin of tergite 5 with short dark spines laterally and posterior margins of tergite 6-7 with short dark spines along whole length. Timbal covering (Fig. 90) as in $D$. spiculata. Sternite 7 emarginate posteromedially, with a sinuous transverse groove at two thirds from its base, unicolorous ochraceous or darkened along posterior margin

Genitalia (Figs. 86-87, 89): Colour as in $D$. spiculata. Basal pygofer lobes pronounced and pointed (Figs. 86-87). Basal part of uncus semicircular and globose (Fig. 86), with some thick erect hairs on anterior surface and some long pale hairs near bases of uncus lobes. Uncus lobes (Fig. 86) with medial margins straight and touching, curved inwards; distal margin rounded and curved inwards; lateral margins oblique, convergent distally, practically without emargination in ventral view; bases of uncus lobes with some thick erect hairs. Width at laterodistal corners of uncus lobes much less than width at bases.
Female. Operculum pale green, reaching about halfway third abdominal segment, curved around abdomen laterally. Lateral margin distal of lateroproximal lobe smoothly convex; laterodistal corner rounded; distal margin slightly convex; mediodistal corner broadly rounded.

Abdomen: About 0.9 times as long as head and thorax together. Dorsal part of tergites ochraceous; sternites and ventral parts of tergites lighter, sternites with greenish tinge. Tergites 4-7 with brownish lateral spots. Posterior margins of tergites 4 and 5 laterally with few short dark spines; posterior margins of tergites 6 and 7 with spines along whole length; posterior margin of tergite 8 with scattered spines medially. Sternite 7 with rounded posteromedial emargination, corners of emargination rounded.

Genitalia: Pygofer ochraceous, more brownish dorsally; distal part of ovipositor sheath brownish. Dorsal margin of pygofer in lateral view virtually straight, ventral margin weakly convex. Ovipositor sheath just not reaching as far as caudodorsal beak; anal valve just not reaching as far as ovipositor sheath.

Measurements in mm ( $\sigma: \mathrm{n}=3 ; \%: \mathrm{n}=1)$. - Body length: $\sigma$ : 35.0-37.0 (35.8 \pm 0.8$)$, $\%: 31.0$; head width: $\sigma: 10.8-10.9$ $(10.9 \pm 0.0)$, $\%$ : 10.6 ; maximum pronotum width: $\sigma$ : 12.6-12.9 $(12.7 \pm 0.1)$, $९$ : 11.8 ; tegmen length: $\sigma$ : $41.0-42.5$ (41.8 \pm $0.6)$, ㅇ: 40.5 .

Etymology. - Sinbyudaw are the white elephants that had a high status at the Burmese court because they were purported to symbolize an early incarnation of Buddha.

Distribution (Fig. 5). - D. sinbyudaw has a rather wide distribution in Indo-China but not as wide as $D$. spiculata. The ranges partly overlap and $D$. sinbyudaw has the slightly more northerly distribution of the two. It is now recorded from Burma, Laos, and Thailand. See also the remark under the distribution of $D$. laterocurvata.

\section{Acknowledgements}

This study would not have been possible without the help of curators at several institutes: Mr. M.D. Webb and Mrs. J. Margerison-Knight (BMNH), Dr. G.A. Samuelson and Ms. K. Kami 
(BPBM), Dr. E.R. Hoebeke and Dr. J. Liebherr (CUIC), Dr. P.D. Perkins (MCZ), Dr. M. Boulard (MNP), Dr. H. Zettel (NHMW), Mr. J. van Tol (RMNH), Dr. B. Hubley (ROME), Dr. V.P. Gapud and Dr. R.W. Brooks (SEM), Dr. S.J. Fang (TARI), Dr. Zaidi Mohd. Isa (UKMS), Dr. R.C. Froeschner and Dr. M. Epstein (USNM), and Dr. N. Møller Andersen (UZMK). Mr. K. Arakaki (BPBM), Mrs. Margerison-Knight, Dr. Brooks, and Dr. Epstein kindly allowed me to retain some specimens for the ZMA collection.

I am indebted to Dr. A.J. de Boer, Dr. J.P. Duffels, and Prof. Dr. F.R. Schram (Institute for Systematics and Population Biology, University of Amsterdam) for their critical reading of the manuscript. Their useful comments as well as those of an anonymous reviewer further improved the manuscript. Mr. G. Verlaan prepared specimens after the genitalia were dissected. The label in Italian on one of the specimens was translated by Mr. W. Hogenes. The translation of Kato's description of Orientopsaltria was provided by the late Dr. Ishihara.

The investigations were supported by the Life Sciences Foundation (SLW), which is subsidized by the Netherlands Organization for Scientific Research (NWO).

\section{References}

Anonymous, 1906. Andrees allgemeiner Handatlas. Fünfte Auflage: [i-ii], 1-186, pls. 1-207 (Velhagen \& Klasing, Bielefeld / Leipzig).

Anonymous, 1938. Atlas van tropisch Nederland: i-ix, maps 1-31b, captions 1-31b, 1-17 (Koninklijk Nederlands Aardrijkskundig Genootschap \& Topografische Dienst in Nederlandsch-Indië, Amsterdam / Batavia).

Anonymous, 1992a. Nelles road atlas Indonesia: 1-127 (Nelles Verlag GmbH, München).

Anonymous, 1992b. Nelles road atlas Southeast Asia excluding Indonesia: 1-128 (Nelles Verlag $\mathrm{GmbH}$, München).

Anonymous, 1994. The Times atlas of the world (9th comprehensive ed.): i-xlvii, pls. 1-123, 1-218 (Times Books Ltd., London).

Atkinson, E.T., 1884. Notes on Indian Rhynchota, No. 1. J. Asiat. Soc. Beng., 53: 210-233.

Atkinson, E.T., 1886. Notes on Indian Rhynchota, No. 6. Addenda and index. J. Asiat. Soc. Beng., 55: 143-223.

Bloem, J.H. \& J.P. Duffels, 1976. The terpsichore-group of the genus Dundubia Amyot \& Serville, 1843 (Homoptera, Cicadidae). Bull, zool. Mus. Univ. Amsterdam, 5: 141-154.

Chen, K.-F., 1933. A list of Chinese known Cicadidae. Ent. Phytopath., 1 (Suppl.): 1-48.*

Distant, W.L., 1881. Descriptions of new species belonging to the homopterous family Cicadidae. Trans. R. ent. Soc., Lond., 1881: 627-648.

Distant, W.L., 1883. On Rhynchota from Mergui. Ann. Mag. nat. Hist., (5) 11: 169-172.

Distant, W.L., 1888. Descriptions of new species of Oriental Homoptera belonging to the family Cicadidae. Ann. Mag. nat. Hist., (6) 1: 291-298.
Distant, W.L., 1889. A monograph of Oriental Cicadidae, 2: 25-48, pls. III-IV (West, Newman \& Co., London).

Distant, W.L., 1890. A monograph of Oriental Cicadidae, 3: 49-72, pls. V-VI (West, Newman \& Co., London).

Distant, W.L., 1892a. A monograph of Oriental Cicadidae, 5: 97-120, pls. X-XII (West, Newman \& Co., London).

Distant, W.L., 1892b. A monograph of Oriental Cicadidae, 7: 145-158, i-xiv, pl. XV (West, Newman \& Co., London).

Distant, W.L., 1901. Description of a new species of Cicadidae from the Island of Hainan. Entomologist, 34: 247.

Distant, W.L., 1906a. The fauna of British India, including Ceylon and Burma. Rhynchota. Vol. III (HeteropteraHomoptera): i-xiv, 1-503 (Taylor \& Francis, London).

Distant, W.L., 1906b. A synonymic catalogue of Homoptera. Part 1. Cicadidae: 1-207 (Trustees British Museum, London).

Distant, W.L., 1912a. New genera and species of Rhynchota (Homoptera). Ann. Mag. nat. Hist., (8) 9: 640-652.

Distant, W.L., 1912b. Homoptera, fam. Cicadidae, subfam. Cicadinae. Genera Insectorum, 142: 1-64, pls. 1-7.

Distant, W.L., 1916. The fauna of British India, including Ceylon and Burma. Rhynchota. Vol. VI. Homoptera: appendix: i-viii, 1-248 (Taylor \& Francis, London).

Distant, W.L., 1917a. The Homoptera of Indo-China. Ann. Mag. nat. Hist., (8) 19: 100-104.

Distant, W.L., 1917b. The Homoptera of Indo-China. Ann. Mag. nat. Hist., (8) 20: 319-325.

Duffels, J.P., 1968. On the identity of Orientopsaltria montivaga (Distant, 1889) and Orientopsaltria agatha (Moulton, 1911) comb. nov. (Homoptera - Cicadidae). Beaufortia, 15: 79-84.

Duffels, J.P., 1983. Taxonomy, phylogeny and biogeography of the genus Cosmopsaltria, with remarks on the historic biogeography of the subtribe Cosmopsaltriaria (Homoptera: Cicadidae). Pacific Insects Monograph, 39: 1-127.

Duffels, J.P. \& P.A. van der Laan, 1985. Catalogue of the Cicadoidea (Homoptera, Auchenorhyncha) 1956-1980. Series ent., 31: i-xiv, 1-414.

Eliot, J., J. Bickersteth, J. Miller \& G. Matthews (eds.), 1994. Thailand, Indochina \& Burma handbook: 1-864 (Trade \& Travel, Bath).

Gogala, M., 1995. Songs of four cicada species from Thailand. Bioacoustics, 6: 101-116.

Haupt, H., 1918. Neue Homoptera aus dem Provinzial-Museum Hannover. Stettin. ent. Ztg., 79: 82-94.

Hayashi, M., 1975. On the species of the genus Meimuna Distant (Homoptera, Cicadidae) of the Ryukyus. II. Geographic and individual variations and mode of coexistence. Kontyû, 43: 412-421.

Horváth, G., 1898. Hemipteren. Wissenschaftliche Ergebnisse der Reise des Grafen Béla Széchenyi in Ostasien 1877-1880, 2: 549-555.*

ICZN, 1985. International code of zoological nomenclature (3rd ed.): i-xx, 1-338 (International Trust for Zoological Nomenclature in association with British Museum (Natural History). London \& Univ. California Press, Berkeley/ Los Angeles). 
Ishihara, T., 1961. Homoptera of Southeast Asia collected by the Osaka City University Biological Expedition to Southeast Asia 1957-58. In: T. Kira \& T. Umesao (eds.), Nature and life in Southeast Asia: 225-257, pls. 1-4 (Fauna and Flora Research Society, Kyoto, Japan).

Kato, M., 1932a. [Notes on some Chinese Cicadidae] (6). Kontyû, 6: 1-9 [in Japanese].

Kato, M., 1932b. Monograph of Cicadidae: 1-450, pls. 1-4, 1-32.

Kato, M., 1934. Notes on Chinese Cicadidae. Ent. World, 2: 141-161, pls. 61-62.*

Kato, M., 1938. Studies on Chinese Cicadidae in Musée Heude Collection. Bull. Cicadidae Mus., 2: 1-28.*

Kato, M., 1940a. Studies on Chinese Cicadidae in Musée Heude Collection (Homoptera: Cicadidae). Notes Ent. chin., 7: 1-30.

Kato, M., 1940b. On some cicadas from Tai (Siam). Bull. Cicadidae Mus., 11: 1-3.*

Kato, M., 1941. Bibliography on Cicadidae of Japan (IV). Bull. Cicadidae Mus., 12: 1-7.*

Kato, M., 1944a. [No title.] Bull. Cicadidae Mus., 14: 1-8.

Kato, M., 1944b. [No title.] Bull. Cicadidae Mus., 14: 9-10.

Kato, M., 1956. Bulletin of the Cicadidae Museum. The biology of Cicadas: [i-xii], 1-319, pls. 1-46 (Iwasaki Shoten, Jinbocho Kanda, Tokyo).

Kirkaldy, G.W., 1907. Some annotations to M. Distant's recent catalogue of the Cicadidae (Hem.) (1). Annls. Soc. ent. Belg., 51: 303-309.

Kirkaldy, G.W., 1909. A list of Hemiptera of Oriental China. Part 1. Annls. Soc. ent. Belg., 53: 177-183.

Liu, G.K.-C., 1940. New Oriental Cicadidae in the Museum of Comparative Zoölogy. Bull. Mus. comp. Zool. Harv., 87: 73-117, pls. 1-7.

Liu, G.K.-C., 1978. Monograph of Chinese Cicadidae. Q. J. Taiwan Mus., 31: 1-184.

Metcalf, Z.P., 1963a. General catalogue of the Homoptera. Fascicle VIII. Cicadoidea. Part 1. Cicadidae. Section I Tibiceninae: i-vii, 1-585 (North Carolina State College, Raleigh, North Carolina).

Metcalf, Z.P., 1963b. General catalogue of the Homoptera. Fascicle VIII. Cicadoidea. Part 1. Cicadidae. Section II Gaenininae and Cicadinae: 587-919 (North Carolina State College, Raleigh, North Carolina).

Mitra, S.C. \& N. Muraleedharan, 1976. New records of
Cicadidae (Hemiptera: Homoptera) from the Andaman and Nicobar Islands. Newsl. zool. Surv. India, 2: 139.

Moulton, J.C., 1911a. Material for a Fauna Borneensis: a list of Bornean Cicadidae. J. Straits Branch R. Asiat. Soc., 57: 123-155.

Moulton, J.C., 1911b. Two new cicadas from Sarawak, with a note on the Bornean species of the genus Cosmopsaltria, Stal. J. Sarawak Mus., 1: 184-190.

Moulton, J.C., 1917. New species of Cicadidae from Sumatra. Entomologist, 50: 1-3.

Moulton, J.C., 1919. Cicadidae collected in Korinchi, West Sumatra, by Messrs. H.C. Robinson and C. Boden Kloss. J. Fed. Malay St. Mus., 8: 61-66.

Moulton, J.C., 1923. Cicadas of Malaysia. J. Fed. Malay St. Mus., 11: 69-177, pls. 2-5.

Munro, D. (ed.), 1988. Chambers world gazetteer: an A-Z of geographical information. Fifth edition: i-xviii, 1-733; iviii, pls. 1-112 (Chambers, Cambridge).

Noualhier, M., 1896. Note sur les Hémiptères récoltés en Indo-Chine et offerts au Muséum par M. Pavie. Bull. Mus. Hist. nat. Paris, 2: 251-259.

Noualhier, M. \& J. Martin, 1904. Hémiptères recueillis par M. A. Pavie. Mission Pavie Indo-Chine 1879-1895. Études diverses III. Recherches sur l'histoire naturelle de l'Indo-Chine orientale, 3: 167-185, pls. X-XI.

Oshanin, V.T., 1906. Verzeichnis der palaearctischen Hemipteren mit besonderer Berücksichtigung ihrer Verteilung im Russischem Reiche II. Homoptera. I. Lieferung. Ezheg. zool. Muz., 11: i-xvi, 1-192.

Oshanin, V.T., 1908. Verzeichnis der palaearctischen Hemipteren mit besonderer Berücksichtigung ihrer Verteilung im Russischem Reiche II. Homoptera. III. Lieferung. Ezheg. zool. Muz., 13: 385-492.

Overmeer, W.P.J. \& J.P. Duffels, 1967. A revisionary study of the genus Dundubia Amyot \& Serville (Homoptera, Cicadidae). Beaufortia, 14: 29-59.

Schmidt, E., 1932. Verzeichnis der Cicaden des chinesischen Reiches. Peking nat. Hist. Bull., 7: 117-133.

Wu, C.F., 1935. Catalogus insectorum sinensium (Catalogue of Chinese insects), II: i, 1-634 (Fan Memorial Institute of Biology, Beijing).

Received: 9 May 1996 